University of Tennessee Health Science Center

UTHSC Digital Commons

\title{
The Development and Psychometric Testing of a Hypertension Knowledge Instrument in a Vulnerable Population
}

Crescent Elayne Rowell

University of Tennessee Health Science Center

Follow this and additional works at: https://dc.uthsc.edu/dissertations

Part of the Community Health and Preventive Medicine Commons, Health Services Research Commons, Investigative Techniques Commons, and the Public Health Education and Promotion Commons

\section{Recommended Citation}

Rowell, Crescent Elayne, "The Development and Psychometric Testing of a Hypertension Knowledge Instrument in a Vulnerable Population" (2010). Theses and Dissertations (ETD). Paper 226.

http://dx.doi.org/10.21007/etd.cghs.2010.0267.

This Dissertation is brought to you for free and open access by the College of Graduate Health Sciences at UTHSC Digital Commons. It has been accepted for inclusion in Theses and Dissertations (ETD) by an authorized administrator of UTHSC Digital Commons. For more information, please contact jwelch30@uthsc.edu. 


\title{
The Development and Psychometric Testing of a Hypertension Knowledge Instrument in a Vulnerable Population
}

\author{
Abstract \\ The primary objective of the study was to assess the psychometric properties of a hypertension \\ knowledge instrument in a vulnerable population. The secondary objective was to determine the \\ association between hypertension knowledge and outcomes such as systolic and diastolic blood \\ pressure and hemoglobin A1c. \\ A cross-sectional study was conducted using a convenience sample of 196 adults aged 18 years and \\ older with hypertension. Item analysis was conducted to determine the reliability of the instrument. The \\ factor structure was determined and confirmed using exploratory factor analysis and confirmatory factor \\ analysis, respectively. Logistic regression analysis was used to determine the association between \\ hypertension knowledge and hypertension-related outcomes.
}

The Cronbach's alpha for the original hypertension knowledge instrument was 0.597 . Using results from the item analysis and the exploratory factor analysis, the refined instrument produced a Cronbach's alpha of 0.598 . A three-factor solution was confirmed by the confirmatory factor analysis. Hypertension knowledge was not significantly associated with any hypertension-related outcome.

The hypertension knowledge instrument exhibits acceptable psychometric properties. More research needs to be done to confirm the psychometric properties of the instrument and to elucidate the relationship between hypertension knowledge and outcomes.

\section{Document Type}

Dissertation

Degree Name

Doctor of Philosophy (PhD)

\section{Program}

Health Science Administration

\section{Research Advisor}

Dick R. Gourley, Pharm.D.

\section{Keywords}

hypertension, knowledge, psychometrics

\section{Subject Categories}

Analytical, Diagnostic and Therapeutic Techniques and Equipment | Community Health and Preventive Medicine | Health Services Research | Investigative Techniques | Medicine and Health Sciences | Public Health | Public Health Education and Promotion 
The Development and Psychometric Testing of a Hypertension Knowledge Instrument in a Vulnerable Population

\author{
A Dissertation \\ Presented for \\ The Graduate Studies Council \\ The University of Tennessee \\ Health Science Center
}

\begin{abstract}
In Partial Fulfillment
Of the Requirements for the Degree

Doctor of Philosophy

From The University of Tennessee
\end{abstract}

By

Crescent Elayne Rowell

December 2010 


\section{Copyright (C) 2010 by Crescent Elayne Rowell}

All rights reserved 


\section{Dedication}

This dissertation is dedicated to my parents, James and Elaine Rowell, who have always believed in me and pushed me to stretch my limits and to always go for what I want. I also dedicate this dissertation to my siblings, Courtney, Candra, and Trae who stuck by me through this process and were always ready to lend an ear. Without their love and support, this process would have been harder, longer, and very lonely. Thank you for travelling along this dissertation journey with me. 


\section{Acknowledgements}

First, I would like to thank my research advisor, Dean Dick Gourley, for all of his support and guidance not only through the doctoral program and dissertation process but also through the doctor of pharmacy program at the University of Tennessee College of Pharmacy. In addition to Dean Gourley, I would also like to thank my other committee members, Drs. Samuel Dagogo-Jack, Robert Nolly, Shelley White-Means, and George Relyea. Without their diligence and dedication, this dissertation would not have been possible. Finally, I would like to thank Drs. Christa George and Amanda HowardThompson for allowing me to conduct my study at their practice site. 


\begin{abstract}
The primary objective of the study was to assess the psychometric properties of a hypertension knowledge instrument in a vulnerable population. The secondary objective was to determine the association between hypertension knowledge and outcomes such as systolic and diastolic blood pressure and hemoglobin A1c.

A cross-sectional study was conducted using a convenience sample of 196 adults aged 18 years and older with hypertension. Item analysis was conducted to determine the reliability of the instrument. The factor structure was determined and confirmed using exploratory factor analysis and confirmatory factor analysis, respectively. Logistic regression analysis was used to determine the associated between hypertension knowledge and hypertension-related outcomes.
\end{abstract}

The Cronbach's alpha for the original hypertension knowledge instrument was 0.597 . Using results from the item analysis and the exploratory factor analysis, the refined instrument produced a Cronbach's alpha of 0.598. A three-factor solution was confirmed by the confirmatory factor analysis. Hypertension knowledge was not significantly associated with any hypertension-related outcome.

The hypertension knowledge instrument exhibits acceptable psychometric properties. More research needs to be done to confirm the psychometric properties of the instrument and to elucidate the relationship between hypertension knowledge and outcomes. 


\section{Table of Contents}

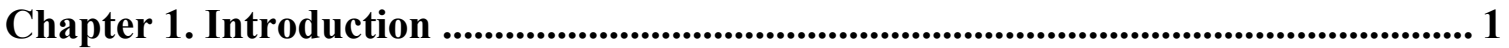

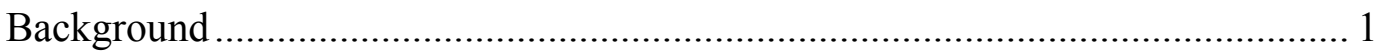

Description of the Problem .......................................................................... 1

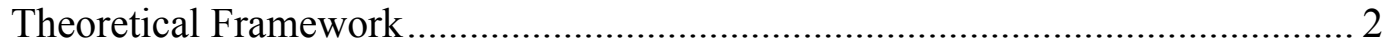

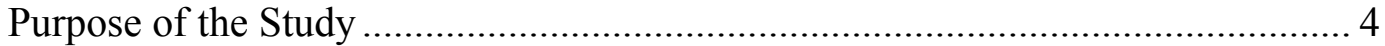

Study Objectives and Research Questions....................................................... 4

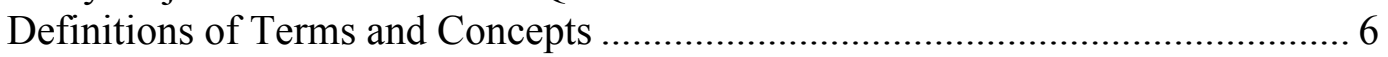

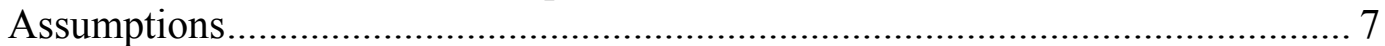

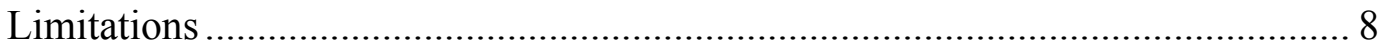

Relevance to Health Outcomes and Policy Research ...................................... 8

Organization of the Dissertation ................................................................ 8

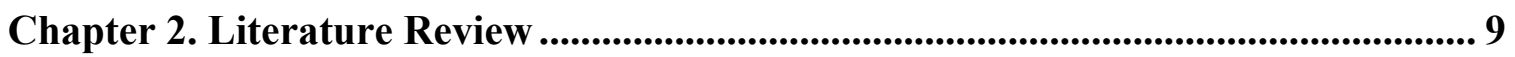

Cost and Prevalence of Hypertension ............................................................. 9

Treatment Guidelines for Hypertension........................................................ 9

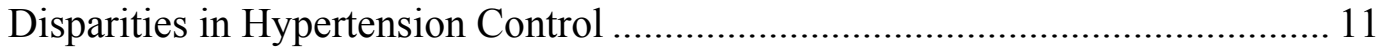

Relationship of Hypertension Control and Diabetes Complications .................... 15

Systolic Hypertension in the Elderly Program (SHEP) ......................... 15

UK Prospective Diabetes Study (UKPDS) ........................................ 18

Hypertension Optimal Treatment Trial (HOT) ..................................... 18

Systolic Hypertension in Europe Trial (Syst-Eur) ................................. 18

Action in Diabetes and Vascular Disease: Preterax and Diamicron MR

Controlled Evaluation (ADVANCE) .................................................... 19

ADVANCE: Retinal Measurements Study (AdRem)........................... 19

Relationship of Health Literacy and Health Outcomes ..................................... 20

Hypertension Knowledge Instruments in the Literature .................................... 22

Relationship of Hypertension Knowledge and Hypertension Outcomes ............. 36

Chapter 3. Methodology .............................................................................................................. 37

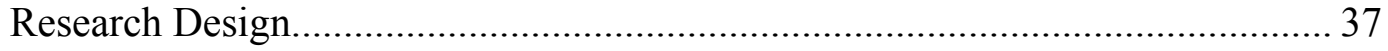

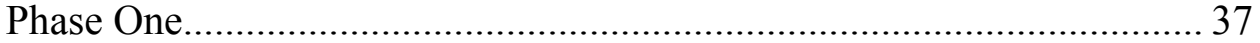

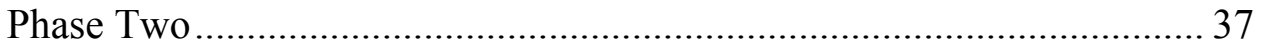

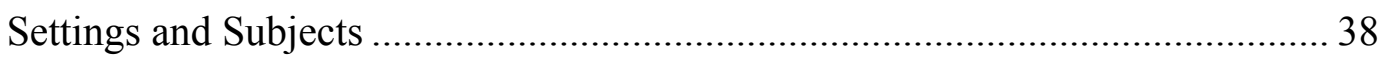

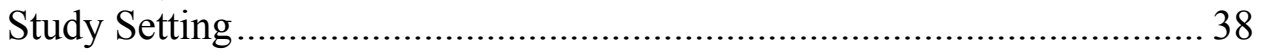

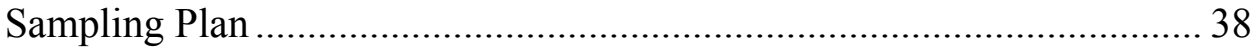

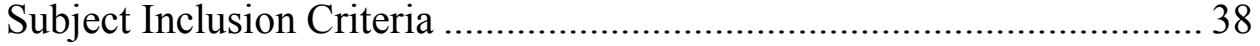

Subject Exclusion Criteria ............................................................... 38

Instrumentation and Operationalization of Variables ...................................... 38

Hypertension Knowledge Instrument .......................................... 38

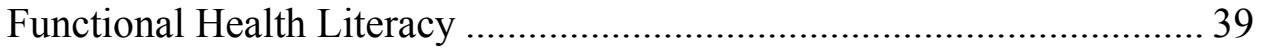

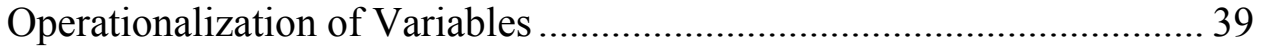

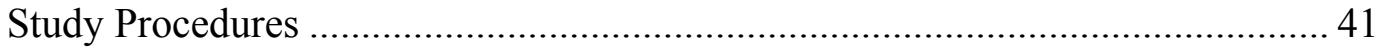

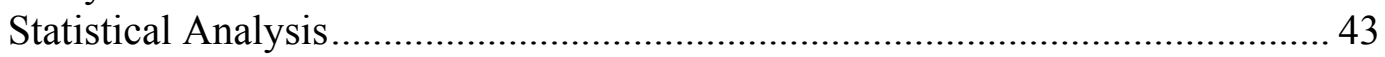

Sample Size Estimation ............................................................. 43 


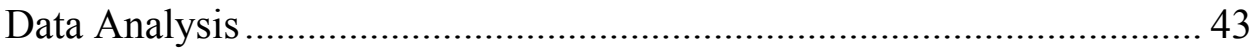

Consideration of Human Subjects ................................................................. 45

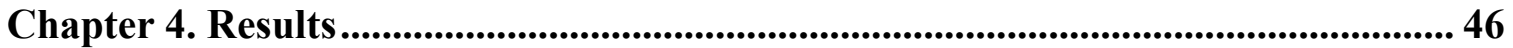

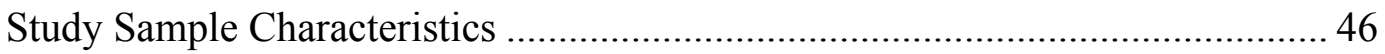

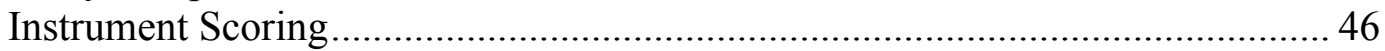

Item Analysis and Exploratory Factor Analysis ........................................... 49

Original Hypertension Knowledge Instrument .................................... 49

Final Hypertension Knowledge Instrument ............................................ 55

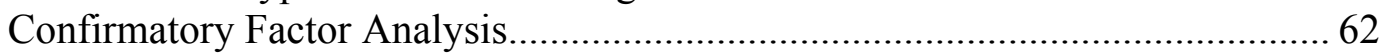

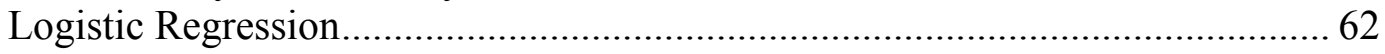

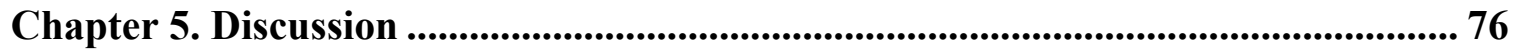

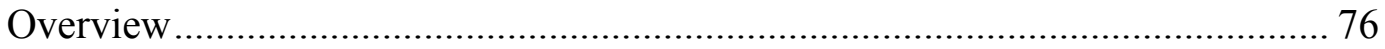

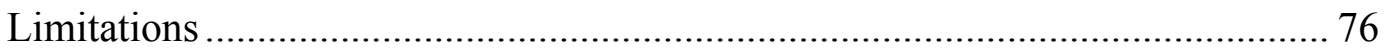

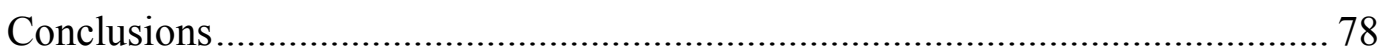

Recommendations for Future Research .................................................... 79

List of References................................................................................................................... 81

Appendix A. Permissions ............................................................................................... 89

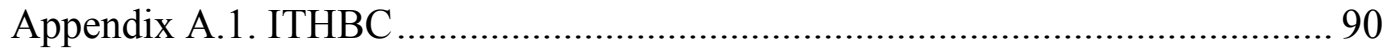

Appendix A.2. JNC-VII......................................................................... 91

Appendix A.3. TPA Hypertension Knowledge Questionnaire ............................ 93

Appendix A.4. AHA High Blood Pressure Quiz ................................................ 94

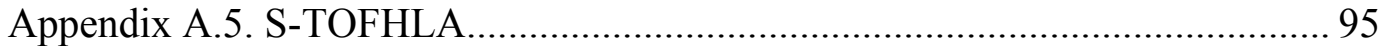

Appendix A.6. Interview Flowchart ........................................................... 96

Appendix B. Institutional Review Board Documents............................................97

Appendix B.1. UT IRB Approval 1 …....................................................... 98

Appendix B.2. UT IRB Approval 2 ….................................................... 99

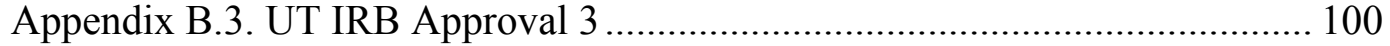

Appendix B.4. UT IRB Approval 4 .............................................................. 102

Appendix B.5. Study Cover Letter ................................................................. 104

Appendix B.6. UTMG IRB Approval......................................................... 105

Appendix B.7. Interview Flow Chart............................................................. 106

Appendix C. Study Instruments .............................................................................. 107

Appendix C.1. Hypertension Knowledge Instrument....................................... 108

Appendix C.2. S-TOFHLA ................................................................... 119

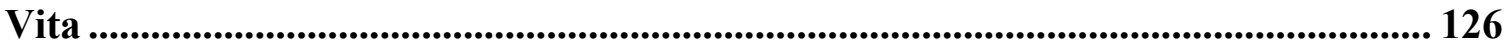




\section{List of Tables}

Table 2.1. Classification of blood pressure for adults............................................ 10

Table 2.2. Lifestyle modifications to prevent and manage hypertension ................. 12

Table 2.3. Clinical trial and clinical guideline basis for compelling indications for individual drug classes .................................................................... 14

Table 2.4. Studies addressing relationship between hypertension control and diabetes complications .............................................................. 16

Table 2.5. Commonly referenced health literacy instruments ................................. 21

Table 2.6. Studies evaluating relationship between health literacy and ECHO ....... 23

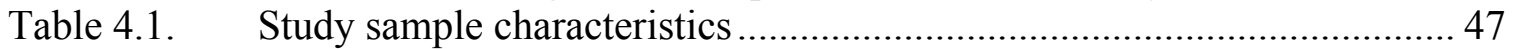

Table 4.2. Item means, variances, and standard deviations for original hypertension knowledge instrument ............................................ 50

Table 4.3. Original hypertension knowledge instrument inter-item correlation

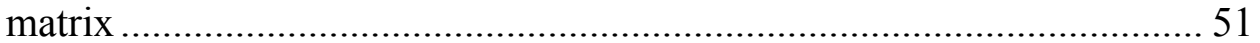

Table 4.4. Original hypertension knowledge instrument item-total statistics............52

Table 4.5. Original hypertension knowledge instrument EFA communalities.......... 53

Table 4.6. EFA rotated factor matrix of original hypertension knowledge

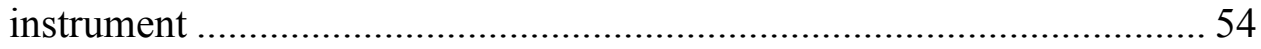

Table 4.7. Item means, variances, and standard deviations for the refined hypertension knowledge instrument ............................................... 57

Table 4.8. Inter-item correlation matrix for final hypertension knowledge

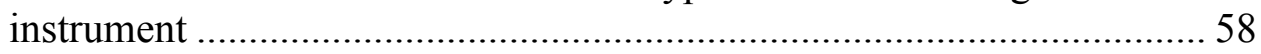

Table 4.9. Final hypertension knowledge instrument item-total statistics................59

Table 4.10. Final hypertension knowledge instrument EFA communalities .............. 60

Table 4.11. EFA rotated factor matrix of final hypertension knowledge instrument .. 61

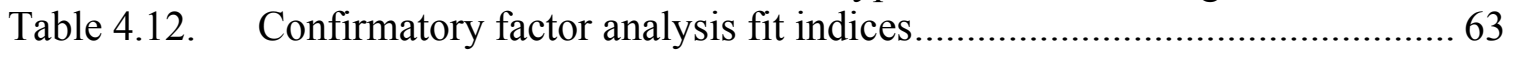

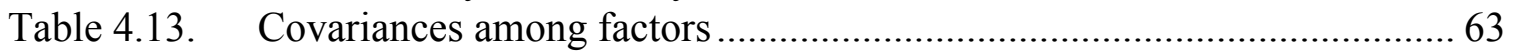

Table 4.14. Final regression model for systolic blood pressure control ..................... 65

Table 4.15. Final regression model for diastolic blood pressure control..................... 67

Table 4.16. Final regression model for total blood pressure control .......................... 69

Table 4.17. Final regression model for serum creatinine within normal limits ........... 71

Table 4.18. Final regression model for HbA1c control ........................................... 74 


\section{List of Figures}

Figure 1.1. Integrated Theory of Health Behavior Change ..................................... 3

Figure 1.2. Conceptual framework of Integrated Theory of Health Behavior

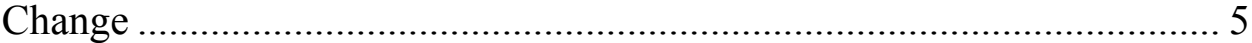

Figure 2.1. Algorithm for treatment of hypertension .............................................. 13

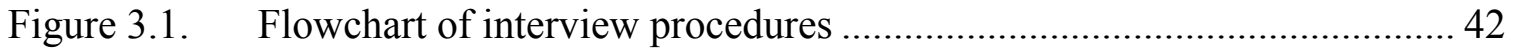

Figure 4.1. Exploratory factor analysis scree plot indicating three factor structure ... 56 


\section{List of Abbreviations}

ACEI

AdRem

ADVANCE

ARB

$\mathrm{BB}$

CCB

CFA

DASH

DBP

EFA

ESRD

GED

$\mathrm{HbAlc}$

HDFP

HOT

ICD-9

IDR

IRB

ITHBC

JNC-7

$\mathrm{KMO}$

KR-20

MART

NAAL

NCES

NHANES

PASW

PIAT-R

REALM

SBP

Scr

SHEP

SORT-R

S-TOFHLA

Syst-Eur

TOFHLA

UKPDS

WRAT-R angiotensin-converting enzyme inhibitor ADVANCE: Retinal Measurements Study Action in Diabetes and Vascular Disease:

Preterax and Diamicron MR Evaluation angiotensin receptor blocker ...beta blocker calcium channel blocker confirmatory factor analysis Dietary Approaches to Stop Hypertension diastolic blood pressure exploratory factor analysis end stage renal disease General Education Diploma hemoglobin Alc Hypertension Detection and Follow-up Program . Hypertension Optimal Treatment Trial International Classification of Disease, 9th Revision Instrument for the Diagnosis of Reading institutional review board .Integrated Theory of Health Behavior Change Seventh Report of the Joint National Committee on Prevention, Detection, Evaluation, and Treatment of High Blood Pressure Kaiser-Meyer-Olkin Kuder-Richardson formula 20 Medical Terminology Achievement Reading Test National Assessment of Adult Literacy National Center for Education Statistics National Health and Nutrition Examination Survey Predictive Analytic Software Peabody Individual Achievement Test-Revised .Rapid Estimate of Adult Literacy in Medicine systolic blood pressure serum creatinine Systolic Hypertension in the Elderly Program Slosson Oral Reading Test-Revised Short form Test of Functional Health Literacy in Adults Systolic Hypertension in Europe Test of Functional Health Literacy in Adults UK Prospective Diabetes Study Wide Range Achievement Test Revised 


\section{Chapter 1. Introduction}

\section{Background}

Hypertension, which is defined as a systolic blood pressure greater than or equal to 140 $\mathrm{mmHg}$ and a diastolic blood pressure blood pressure greater than or equal to $90 \mathrm{mmHg}$ or taking medication to control hypertension, affected approximately $29 \%$ of Americans aged 18 years and older in 2005-2006. ${ }^{1}$ A cardiovascular disease in and of itself, hypertension not only puts people at an increased risk for other cardiovascular diseases but also for stroke and renal disease. Interestingly, in 2003-2004, 75\% of patients who reported having diabetes also reported having hypertension. ${ }^{2}$ Hypertension and diabetes are responsible for a large percentage of the morbidity and mortality in the United States. In 2006, heart disease, diabetes, and hypertension were the first, sixth, and thirteenth leading causes of death in the United States. ${ }^{3}$

Studies have shown that small reductions in blood pressure can lead to significant reductions in microvascular and macrovascular complications. ${ }^{4}$ Because a large majority of patients with diabetes also have hypertension, efforts have recently turned towards reducing diabetes-related complications by controlling the blood pressure of patients with diabetes. The Systolic Hypertension in the Elderly Program (SHEP), the Hypertension Detection and Follow-up Program (HDFP), and the Systolic Hypertension in Europe (Syst-Eur) studies all involve the reduction of blood pressure in patients with diabetes in an attempt to lower the risk for cardiovascular complications. These studies all found significant reduction in the risk for cardiovascular complications and mortality by intensively treating diabetic patients' blood pressure. ${ }^{5}$ Other studies have shown that successfully managing hypertension, especially with angiotensin-converting enzyme inhibitors, results in improved renal and retinal outcomes. ${ }^{6-10}$

\section{Description of the Problem}

As the age-adjusted prevalence of hypertension in non-institutionalized people aged 20 years and older increased from $25.5 \%$ in 1988-1994 to 31.3\% in 2003-2006, health care providers have focused their attention on not only drug therapy management of hypertension but also on educational interventions that increase patients' knowledge of the necessary self-care behaviors and risks associated with uncontrolled hypertension. ${ }^{11,12}$ This increase in educational interventions aimed at increasing patient disease state and self-care knowledge has led to the need for instruments that assess whether patients are actually acquiring the intended knowledge. Currently, in the literature there are numerous instruments used to assess patients' knowledge about their hypertension. These instruments vary in the soundness of their psychometric properties and in their actual content and design. ${ }^{13-19}$ The formats of the available instruments range from a true/false format to Likert-type responses, which appear to measure outcome expectancies and not actual knowledge. Interestingly, none of the hypertension knowledge instruments available utilize a multiple-choice format as this study proposed 
to do. By developing a psychometrically sound instrument that assessed hypertensive patients' knowledge base, the study will make it possible to quantitatively determine if the patient has acquired the knowledge necessary to meet their hypertensive health care demands.

\section{Theoretical Framework}

The theoretical framework for the study was adapted with permission from the Integrated Theory of Health Behavior Change (ITHBC) (Appendix A). Although ITHBC is a new theory, having first been reported in the literature in 2009, it is a descriptive mid-range theory that seeks to identify and describe the factors that explain health behavior change. ${ }^{20}$ The ITHBC was developed from components of interventions in the literature that produced behavior change in the populations being studied. Additionally, the theory incorporates other theories that address health behavior change, social support, and selfmanagement of chronic disease states in order to more completely describe the dynamic process of health behavior change. ${ }^{20}$

Before one can really understand the constructs and relationships of the ITHBC, one must have knowledge of the assumptions on which the theory is based. The ITHBC is based on the following assumptions: ${ }^{20}$

Behavior change is a dynamic iterative process. Desire and motivation are prerequisites to change, and self-reflection facilitates progress. Positive social influences sway one's interest and willingness just as positive relationships help to support and sustain change. Engagement in healthy behavior is an outcome that can be realized in the short term (a proximal outcome), and engagement in health behavior influences and leads to improvement in health status, the distal outcome (Ryan 2009, p. 164).

The ITHBC is composed of three major constructs that come together to fully explain health behavior change: knowledge and beliefs, self-regulation skill and ability, and social facilitation. ${ }^{20}$ According to the ITHBC, no one construct by itself can cause behavior change. Instead, it is the relationships between the constructs that exact change. ${ }^{20}$ Figure 1.1 illustrates the relationship between an individual's knowledge and beliefs, self-regulation skill and ability, and social facilitation, which in turn result in the engagement in self-management behavior and the improvement in health status. ${ }^{20}$ As can be seen in Figure 1.1, increased knowledge and positive social influence leads an engagement in self-care skill and ability. This engagement in self-regulation skill and ability leads to the engagement in self-management behaviors, when then causes and improvement status. ${ }^{20}$

Because the current study sought to examine the relationship between condition-specific (hypertension) knowledge and health status, the ITHBC was adapted as the theoretical framework for the study. The advantage that the ITHBC has over other health behavior change theories is that it explicitly takes into account disease state knowledge as well as 


\section{Knowledge \& Beliefs}

Condition specific

Knowledge

Personal perceptions

Self-efficacy

Outcome expectancy

Goal congruence

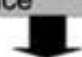

Self-Regulation Skill and Ability

Goal Setting

Self-Monitoring \& Reflective Thinking

Decision Making

Planning and Plan Enactment

Self-evaluation

Management of Emotional Response

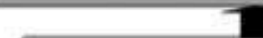

Social Facilitation

Influence

Support

(Emotional, instrumental,

informational)

\section{Figure 1.1. Integrated Theory of Health Behavior Change}

Reprinted with permission from Lippincott Williams \& Wilkins. Ryan P. Integrated Theory of Health Behavior Change: Background and intervention development. Clin Nurse Spec 2009;23:161-170. 
other constructs such as social facilitation. Figure 1.2 depicts the adaption of the ITHBC for the knowledge instrument that was used in this study to measure hypertension knowledge and to examine its relationship with health status.

Based on Figure 1.2, the theoretical framework for the study proposed that higher scores on the hypertension knowledge instrument would enhance self-regulation skill and ability. Additionally, social facilitators such as being married, higher level of educational attainment, insurance status, higher functional health literacy, as measured by the short form Test of Functional Health Literacy in Adults (S-TOFHLA), would also enhance self-regulation skill and ability. Self-regulation skill and ability would then result in the engagement of self-management behavior. The variable number of hypertension-related complications was included as a representation of the engagement in self-care behavior because as the number of complications increases, the number of self-care behaviors that an individual must engage in also increases. Therefore, it was believed that this increase in the number of disease-specific self-care behaviors would take focus away from hypertension self-care behaviors and result in decreased health status with respect to hypertension. The engagement in self-management behavior would result in improved health status as evident by blood pressure at goal, a serum creatinine (Scr) within normal limits, and a hemoglobin A1c (HbA1c) at goal.

\section{Purpose of the Study}

The primary purpose of the study was to describe the development and validation of an instrument that assessed the knowledge required of patients with hypertension to effectively manage their blood pressure. The secondary purpose of the study was to determine the association between hypertension knowledge and outcomes such as systolic and diastolic blood pressure and HbA1c. Other outcomes investigated are known complications of hypertension: history of congestive heart failure, stroke, myocardial infarction, peripheral vascular disease, elevated Scr, and end stage renal disease (ESRD).

\section{Study Objectives and Research Questions}

The study objectives and their respective research questions were:

1. Create an instrument and assess the psychometric properties of the hypertension knowledge instrument.

a. What is the factor structure make-up of the instrument?

b. Does the instrument exhibit acceptable reliability with respect to internal consistency?

2. Assess whether scores on the hypertension knowledge instrument are associated with hypertension-related outcomes.

a. How do scores on the hypertension knowledge instrument correlate with systolic blood pressure control? 


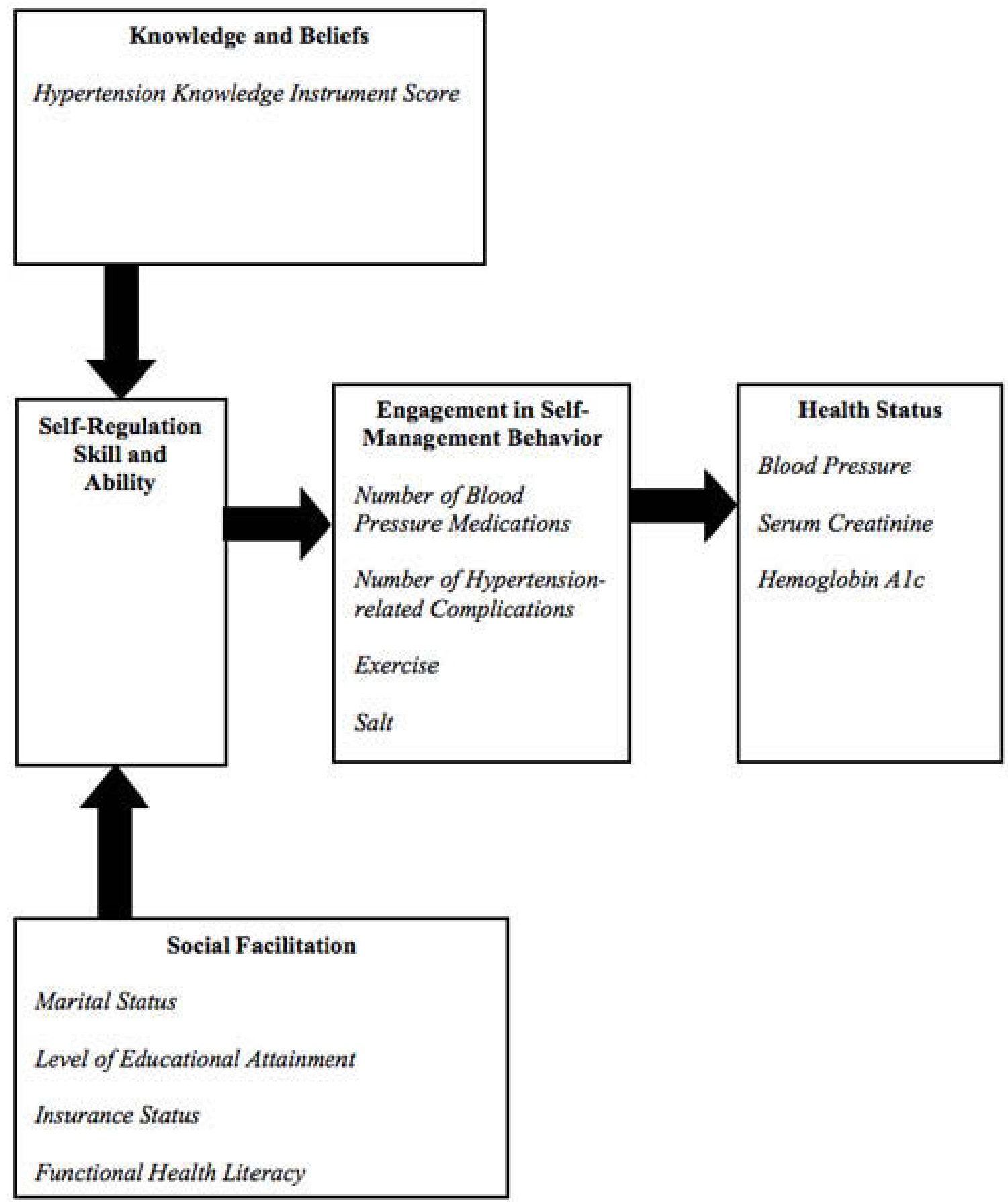

Figure 1.2. Conceptual framework of Integrated Theory of Health Behavior Change

Note: Words in italics are variables to be measured.

Modified with permission from Lippincott Williams \& Wilkins. Ryan P. Integrated Theory of Health Behavior Change: Background and intervention development. Clin Nurse Spec 2009;23:161-170. 
b. How do scores on the hypertension knowledge instrument correlate with total blood pressure control?

c. How do scores on the hypertension knowledge instrument correlate with having a serum creatinine within normal limits?

d. How do scores on the hypertension knowledge instrument correlate with having a hemoglobin Alc at goal?

\section{Definitions of Terms and Concepts}

Beliefs: Beliefs refer to how a person feels about a disease state or a necessary health behavior. ${ }^{20}$

Diabetes mellitus: Diabetes mellitus is defined as a fasting plasma glucose of greater than or equal to $126 \mathrm{mg} / \mathrm{dL}$ or a 2-hour plasma glucose level greater than or equal to 200 $\mathrm{mg} / \mathrm{dL}{ }^{21}$

Functional health literacy: Functional health literacy is context specific and is the ability to read and comprehend healthcare-related materials. ${ }^{22}$

Goal congruence: Goal congruence refers to the process that an individual goes through in order to satisfy the demands necessary to achieve their health goals. ${ }^{20}$

Hemoglobin A1c: Hemoglobin A1c, HbAlc, is the amount of glycolated hemoglobin in an individual's blood. Hemoglobin A1c is often used as a measure of glucose control over the past 3 months. For individuals without diabetes, HbAlc is normally less than $6 \%$. For individuals with diabetes, a HbAlc goal of less than $7 \%$ is desired. ${ }^{23}$

Hypertension: Hypertension is defined as a systolic blood pressure greater than or equal to $140 \mathrm{mmHg}$ and a diastolic blood pressure greater than or equal to $90 \mathrm{mmHg}$ or having a diagnosis by a health care provider of hypertension. ${ }^{24}$

Hypertension knowledge: Hypertension knowledge is the factual information regarding the complications, medication therapy, and self-care behavior necessary for effective management of hypertension. ${ }^{20}$

Knowledge: Knowledge is factual information. ${ }^{20}$

Macrovascular complications: Macrovascular complications are complications of the large vessels in the body and include coronary artery disease, peripheral arterial disease, and stroke. $^{25}$

Microvascular complications: Microvascular complications are complications of the small vessels in the body and include nephropathy, neuropathy, and retinopathy. ${ }^{25}$ 
Outcome expectancy: Outcome expectancy is the belief that a certain behavior will yield a particular outcome. ${ }^{20}$

Predictive Analytic Software $\left(\mathrm{PASW}^{\circledR}\right)$ : $\mathrm{PASW}^{\circledR}$ is a statistical software package (Version 18, IBM Corporation, Somers, NY) used to analyze the data. ${ }^{26}$

Psychometrics: Psychometrics is a psychological field of study concerned with the theory and technique of test measurment. ${ }^{27}$

Reliability: Reliability is the ability of an instrument to measure the intended underlying dimensions. $^{28}$

SAS $^{\circledR}$ : SAS ${ }^{\circledR}$ is a statistical package. The confirmatory factor analysis was generated using SAS software, Version 9.1.3 of the SAS System for Windows XP. Copyright (C) 2007 SAS Institute Inc. SAS and all other SAS Institute Inc. product or service names are registered trademarks or trademarks of SAS Institute Inc., Cary, NC, USA. ${ }^{29}$

Self-care behaviors: Self-care behaviors are the condition-specific behaviors that individuals must engage in to effectively and successfully manage their condition.

Self-efficacy: Self-efficacy is the confidence that one can change their situation. ${ }^{20}$

Self-regulation: Self-regulation is the process that individuals must go through in order to successfully incorporate new behaviors into their lifestyles. ${ }^{20}$

Social facilitation: Social facilitation is the positive influence derived from the support of an individual's community, family, and healthcare providers that aids in the engagement of self-care behaviors. ${ }^{20}$

Social influence: Social influence refers to the ability to convince an individual to behave in a certain manner. ${ }^{20}$

Social support: Social support is the support necessary to successfully engage in self-care behaviors. $^{20}$

Test of Functional Health Literacy in Adults (TOFHLA): The Test of Functional Health Literacy in Adults is a validated and accepted measure of health literacy. ${ }^{30}$

\section{Assumptions}

The assumptions of the study included the following:

1. The respondents of the instrument responded to the best of their knowledge.

2. Each respondent completed the instrument only once.

3. The study sample was representative of the target population. 


\section{Limitations}

The limitations of the study included the following:

1. The study utilized a convenience sampling technique. Therefore, the results of the study were not generalizable to the general population.

2. Study participants were asked to recall their past medical histories and therefore recall bias was potentially a problem.

\section{Relevance to Health Outcomes and Policy Research}

As evident in the literature, there is currently a lack of psychometrically sound instruments that assess knowledge about complications of hypertension, symptoms, and self-care behaviors necessary to successfully manage hypertension. These tools tend to measure outcome expectancies rather than knowledge and many of them have not had their psychometric properties assessed adequately. ${ }^{14-16,18}$ Additionally, some of the existing instruments utilize a true/false response format and thus the participant has a high probability of guessing correctly. ${ }^{19,31,32}$ Therefore, the results of this study will fill a gap in the literature.

Additionally, it is hoped that the instrument will be clinically useful. As health care providers continue to work to improve patient outcomes with respect to hypertension, the instrument will provide a visual method to express to patients the relationship between their knowledge and their potential for hypertension-related outcomes. Finally, the instrument will provide health care providers with helpful information regarding which areas of hypertension the patient needs to continue to address.

\section{Organization of the Dissertation}

The dissertation is organized into five chapters. Chapter 1, the introductory chapter, provides the rationale and relevance for the study. Chapter 2 provides an in-depth review of the literature in which the relationship between blood pressure control and diabetes outcomes is discussed. The recommendations for the effective self-care management of hypertension in addition to the current hypertension knowledge tools are also reviewed in Chapter 2. Chapter 3 covers the methodology of the study while Chapter 4 provides the results of the study analyses. Finally, Chapter 5 not only discusses the results and conclusions of the study but also provides a discussion of the study's limitations and recommendations for future research. 


\section{Chapter 2. Literature Review}

Hypertension is associated with extensive morbidity and mortality and costs billions of dollars each year to manage and treat, thereby placing a substantial burden on society. In order to fully understand the drug therapy and lifestyle activities that are essential to the successful treatment and management of hypertension, the Seventh Report of the Joint National Committee on Prevention, Detection, Evaluation, and Treatment of High Blood Pressure (JNC-7) guideline is presented. Because the study site serves mainly minority patients, the disparity in hypertension control between blacks and white is also examined. Finally, the relationship between health literacy and health outcomes and hypertension knowledge and hypertension outcomes are discussed in order to present why disease state knowledge and literacy are important in and necessary to achieve clinical goals.

\section{Cost and Prevalence of Hypertension}

In 2001, uncontrolled blood pressure globally cost $\$ 370$ billion. $^{33}$ For the same year, the United States' incremental annual direct cost for patients with hypertension was \$54 billion dollars, after controlling for demographics and co-morbidities. The United States' mean incremental annual per capital direct cost for a hypertensive patient was $\$ 1,131$. Prescription medications and inpatient and outpatient visits were responsible for more than $90 \%$ of the overall incremental cost of treating hypertension. ${ }^{34}$

From 2003-2006, the age-adjusted prevalence of hypertension in adults aged 20 years and older was $31.3 \%$ of the population. The prevalence of hypertension in non-Hispanic white males was $31.2 \%$. Additionally, $28.3 \%$ of non-Hispanic white females had either elevated blood pressure and/or were taking antihypertensive medications. Among nonHispanic black males and females, $42.2 \%$ and $44.1 \%$, respectively, had hypertension during this time period. ${ }^{35}$ The 2003-2006 prevalence rates for both non-Hispanic whites and non-Hispanic blacks were increases from previous years, with the 1999-2002 prevalence rates for non-Hispanic white males and females being $27.6 \%$ and $28.5 \%$, respectively, and the rates for non-Hispanic black males and females being $40.6 \%$ and $43.5 \%$, respectively. ${ }^{35}$

\section{Treatment Guidelines for Hypertension}

The current hypertension treatment guidelines, Seventh Report of the Joint National Committee on Prevention, Detection, Evaluation, and Treatment of High Blood Pressure (JNC-7), were published in 2003. ${ }^{24}$ The JNC-7 guidelines classify blood pressure into four categories: normal, prehypertension, stage 1 hypertension, and stage 2 hypertension. Table 2.1 outlines the systolic (SBP) and diastolic (DBP) blood pressures that fall within each category. ${ }^{24}$ 
Table 2.1. Classification of blood pressure for adults

\begin{tabular}{lcc}
\hline \multicolumn{1}{c}{ BP Classification } & SBP $\mathbf{~ m m ~ H g}$ & DBP $\mathbf{~ m m ~ H g}$ \\
\hline Normal & $<120$ & and $<80$ \\
Prehypertension & $120-139$ & or $80-89$ \\
Stage 1 hypertension & $140-159$ & or $90-99$ \\
Stage 2 hypertension & $\geq 160$ & or $\geq 100$ \\
\hline
\end{tabular}

Reprinted with permission from Lippincott Williams \& Wilkins. Chobanian AV, Bakris GL, Black HR et al. Seventh Report of the Joint National Committee on Prevention, Detection, Evaluation, and Treatment of High Blood Pressure. Hypertension 2003;42:1206-1252. 
JNC-7 guidelines recommend that individuals with normal hypertension have their blood pressure rechecked in two years. Individuals with prehypertension should be rechecked in one year and also be provided with information regarding lifestyle modifications. Patients with stage 1 hypertension should have their diagnosis confirmed and begin drug therapy within two months and also be instructed in the appropriate lifestyle modifications to manage their blood pressure. Finally, those with stage 2 hypertension should be treated with drug therapy within one month of diagnosis. As recommended for those who are classified as having prehypertension and stage 1 hypertension, individuals with stage 2 hypertension should be given advice about lifestyle modifications in conjunction with beginning medication therapy. ${ }^{24}$ The lifestyle modifications and the reductions in SBP associated with adopting the respective lifestyle modification are listed in Table 2.2. ${ }^{24}$

The medications used in the treatment of hypertension include diuretics (thiazides, loop, potassium-sparing, and aldosterone receptor blockers); beta blockers, BBs; angiotensinconverting enzyme inhibitors, ACEIs; angiotensin receptor blockers, ARBs; calcium channel blockers, CCBs; alpha-1 blockers; alpha-2 agonists; and direct vasodilators. Currently, thiazide diuretics are recommended as first-line therapy with the addition of a different class of hypertensive medication if an individual is not controlled on a thiazide. The algorithm for the treatment of hypertension recommended by the JNC-7 guidelines is illustrated in Figure 2.1. Table 2.3 lists the treatment recommendations for patients with compelling indications in conjunction with hypertension.

\section{Disparities in Hypertension Control}

Although, the raw 2005-2006 National Health and Nutritional Examination Survey (NHANES) data indicated no disparities in hypertension control among individuals who had hypertension and being treated, previous years' data indicate a significant disparity between non-Hispanic white and black hypertensive patients being treated with antihypertensive medications. ${ }^{1}$ Hertz et al, using the NHANES 1999-2002 data, found a significant difference in the control of blood pressure among non-Hispanic whites $(59.7 \%)$ and whites $(48.9 \%)$ being treated for their hypertension. After adjusting for insurance status, gender, age, socioeconomic status, weight, and behavioral modifications, non-Hispanic blacks were approximately twice as likely as non-Hispanic whites to not reach their blood pressure goal. ${ }^{36}$ Giles et al found that treated Mexican Americans were 29\% less likely to achieve blood pressure control compared to nonHispanic whites. Additionally, treated non-Hispanic blacks were $41 \%$ less likely to achieve blood pressure control compared to their non-Hispanic white counterparts. ${ }^{37}$ Fiscella et al determined that if in the hypertensive population the mean SBP of blacks were reduced to the mean SBP of whites, then the annual number of deaths in the black population due to cardiovascular disease would be reduced by 5,480 and from stroke by $2,190 .{ }^{38}$ Unfortunately, definitive causal pathways or factors have not been identified.

Studies have sought to understand the differences in blood pressure control between blacks and whites. ${ }^{11,39,40}$ Bosworth et al investigated the potential explanatory factors 
Table 2.2. Lifestyle modifications to prevent and manage hypertension

\begin{tabular}{|c|c|c|}
\hline Modification & Recommendation & $\begin{array}{l}\text { Approximate SBP } \\
\text { Reduction (Range) }\end{array}$ \\
\hline Weight reduction & $\begin{array}{l}\text { Maintain normal body } \\
\text { weight (body mass index } \\
\left.18.5-24.9 \mathrm{~kg} / \mathrm{m}^{3}\right)\end{array}$ & $5-10 \mathrm{~mm} \mathrm{Hg} / 10 \mathrm{~kg}$ \\
\hline $\begin{array}{l}\text { Adopt dietary approaches to } \\
\text { stop hypertension (DASH) } \\
\text { eating plan }\end{array}$ & $\begin{array}{l}\text { Consume a diet rich in } \\
\text { fruits, vegetables, and low- } \\
\text { fat dairy products with a } \\
\text { reduced content of saturated } \\
\text { and total fat }\end{array}$ & 8-14 mm Hg \\
\hline Dietary sodium reduction & $\begin{array}{l}\text { Reduce dietary sodium } \\
\text { intake to no more than } 100 \\
\text { mmol per day ( } 2.4 \mathrm{~g} \text { sodium } \\
\text { or } 6 \mathrm{~g} \text { sodium chloride) }\end{array}$ & $2-8 \mathrm{~mm} \mathrm{Hg}$ \\
\hline Physical activity & $\begin{array}{l}\text { Engage in regular aerobic } \\
\text { physical activity such as } \\
\text { brisk walking (at least } 30 \\
\text { minutes per day, most days } \\
\text { of the week) }\end{array}$ & 4-9 $\mathrm{mm} \mathrm{Hg}$ \\
\hline $\begin{array}{l}\text { Moderation of alcohol } \\
\text { consumption }\end{array}$ & $\begin{array}{l}\text { Limit consumption to no } \\
\text { more than } 2 \text { drinks (i.e., } 24 \\
\text { oz beer, } 10 \text { oz wine, or } 3 \mathrm{oz} \\
80 \text {-proof whiskey) per day } \\
\text { in most men and to no more } \\
\text { than } 1 \text { drink per day in } \\
\text { women and lighter-weight } \\
\text { persons }\end{array}$ & $2-4 \mathrm{~mm} \mathrm{Hg}$ \\
\hline
\end{tabular}

Reprinted with permission from Lippincott Williams \& Wilkins. Chobanian AV, Bakris GL, Black HR et al. Seventh Report of the Joint National Committee on Prevention, Detection, Evaluation, and Treatment of High Blood Pressure. Hypertension 2003;42:1206-1252. 


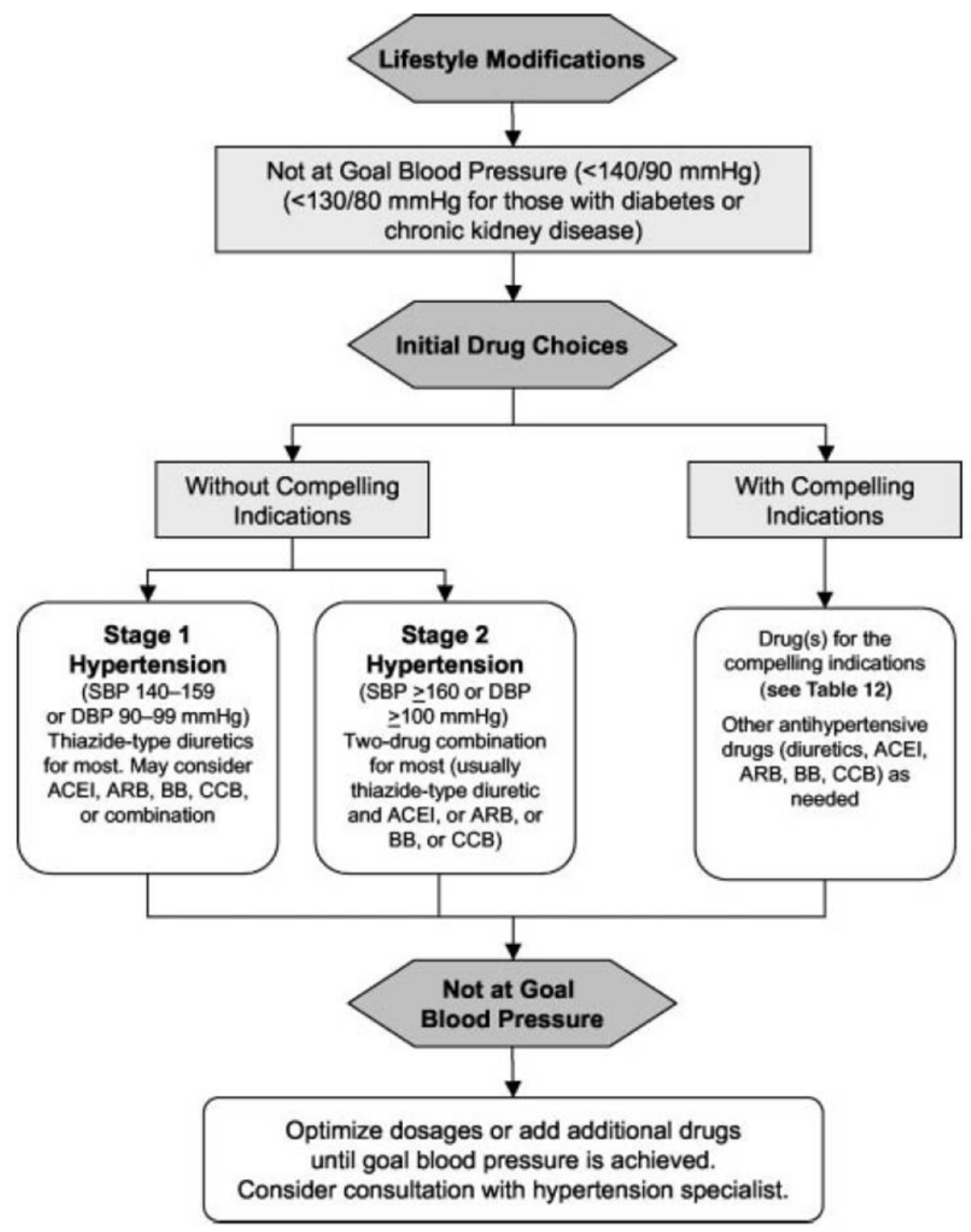

Figure 2.1. Algorithm for treatment of hypertension

Reprinted with permission from Lippincott Williams \& Wilkins. Chobanian AV, Bakris GL, Black HR et al. Seventh Report of the Joint National Committee on Prevention, Detection, Evaluation, and Treatment of High Blood Pressure. Hypertension 2003;42:1206-1252. 
Table 2.3. Clinical trial and clinical guideline basis for compelling indications for individual drug classes

\begin{tabular}{|c|c|c|c|c|c|c|}
\hline \multirow[b]{2}{*}{ Compelling Indication } & \multicolumn{6}{|c|}{ Recommended Drugs } \\
\hline & Diuretic & BB & ACEI & ARB & $\mathbf{C C B}$ & Aldo ANT \\
\hline Heart failure & $\bullet$ & $\bullet$ & $\bullet$ & $\bullet$ & & $\bullet$ \\
\hline Post-myocardial infarction & & • & • & & & • \\
\hline High coronary disease risk & • & • & • & & • & \\
\hline Diabetes & - & • & • & - & - & \\
\hline Chronic kidney disease & & & • & • & & \\
\hline Recurrent stroke prevention & $\bullet$ & & $\bullet$ & & & \\
\hline
\end{tabular}

Notes: BB indicates $\beta$-blocker; ACEI, angiotensin-converting enzyme inhibitor; ARB. Angiotensin receptor blocker; CCB, calcium channel blocker; Aldo ANT, aldosterone antagonist. Compelling indications for antihypertensive drugs are based on benefits from outcome studies or existing clinical guidelines; the compelling indication is managed in parallel with the blood pressure.

Reprinted with permission from Lippincott Williams \& Wilkins. Chobanian AV, Bakris GL, Black HR et al. Seventh Report of the Joint National Committee on Prevention, Detection, Evaluation, and Treatment of High Blood Pressure. Hypertension 2003;42:1206-1252. 
for the racial differences in blood pressure control in two different studies. ${ }^{11,39}$ The first study, conducted in a Veterans Affairs hospital where disparities in access to care would not be a contributory factor, found that blacks were more likely to be nonadherent to medications, more functionally illiterate, have a family member with hypertension, perceive hypertension as serious and to experience increased urination compared to whites. Once these factors were controlled for in the model, the odds of African Americans having adequate blood pressure control compared to whites decreased to 1.59 (95\% CI 1.09-2.29) from 1.70 (95\% CI 1.20-2.41). ${ }^{39}$ In 2008, Bosworth et al conducted a follow-up study to the 2006 study. This study also sought to determine the explanatory factors responsible for the differences seen in blood pressure control between blacks and whites. ${ }^{11}$ In adjusted analyses where the investigators sought to identify factors that modified the relationship between race and blood pressure by greater than $10 \%$, worries about hypertension, medication nonadherence, and age were the only significant factors remaining in the model. ${ }^{11}$ Kressin et al found similar results in a study that investigated the racial disparities in blood pressure control. ${ }^{40}$ Kressin et al found that blacks were more likely to report worse medication adherence, more discrimination, and more concerns about high blood pressure and blood pressure medication. However, once these factors were controlled for in the model, the investigators found that there was no longer a black-white disparity in blood pressure control. ${ }^{11}$

\section{Relationship of Hypertension Control and Diabetes Complications}

Achieving optimal systolic and diastolic blood pressures has been shown to decrease the risk for cardiovascular disease and microvascular and macrovascular complications. However, there is still some controversy as to whether intensive lowering of blood pressure in patients with type 2 diabetes results in a significant reduction in the incidence and progression of diabetes-related complications. The following six studies, also summarized in Table 2.4, all attempted to elucidate the relationship between intensive blood pressure lowering and the risk of complications in patients with type 2 diabetes.

\section{Systolic Hypertension in the EIderly Program (SHEP)}

The SHEP trial was a multicenter, double-blind, placebo-controlled trial conducted in adults 60 years and older with isolated systolic hypertension. ${ }^{41}$ For the SHEP trial, isolated systolic hypertension was defined as a SBP greater than or equal to $160 \mathrm{~mm} \mathrm{Hg}$ and a DBP less than $90 \mathrm{~mm} \mathrm{Hg}$. One of the subgroup analyses conducted from the SHEP study data involved the examination of the effect of a diuretic-based antihypertensive treatment regimen on cardiovascular risk in older patients with diabetes and isolated systolic hypertension compared to their counterparts who only had isolated systolic hypertension at baseline. ${ }^{41}$ The main outcomes for the subgroup analysis were 5-year rates of cardiovascular disease events, nonfatal and fatal stroke, nonfatal myocardial infarction and fatal myocardial infarction, and all-cause mortality. Davis et al found that treatment with a diuretic-based antihypertensive regimen significantly reduced 5-year rates of cardiovascular disease events by $34 \%$ in individuals with and without diabetes. 
Table 2.4. Studies addressing relationship between hypertension control and diabetes complications

\begin{tabular}{|c|c|c|c|c|}
\hline Study & Objective & Sampling & $\begin{array}{c}\text { Study } \\
\text { Design }\end{array}$ & Major Findings \\
\hline $\begin{array}{l}\text { Systolic } \\
\text { Hypertension } \\
\text { in the Elderly } \\
\text { Program } \\
(\text { SHEP) }\end{array}$ & $\begin{array}{l}\text { To assess the effect of } \\
\text { diuretic-based } \\
\text { antihypertensive } \\
\text { treatment regimen on } \\
\text { cardiovascular risk in } \\
\text { older patients with } \\
\text { diabetes and isolated } \\
\text { systolic hypertension }\end{array}$ & $\begin{array}{l}\text { Men and women } \\
\text { aged } 60 \text { years and } \\
\text { older with a SBP } \geq \\
160 \mathrm{~mm} \mathrm{Hg} \text { and a } \\
\mathrm{DBP}<90 \mathrm{~mm} \mathrm{Hg} \\
\mathrm{n}=4,736\end{array}$ & $\begin{array}{l}\text { Multi- } \\
\text { center, } \\
\text { double- } \\
\text { blind } \\
\text { placebo- } \\
\text { controlled }\end{array}$ & $\begin{array}{l}\text { Treatment with a diuretic-based } \\
\text { antihypertensive regimen } \\
\text { significantly reduced 5-year rates of } \\
\text { nonfatal myocardial infarction and } \\
\text { fatal coronary heart disease and } \\
\text { major coronary heart disease by } 54 \% \\
\text { and } 34 \% \text {, respectively. Five-year all- } \\
\text { cause mortality was reduced by } 26 \% \\
\text { in participants with diabetes. }\end{array}$ \\
\hline $\begin{array}{l}\text { UK } \\
\text { Prospective } \\
\text { Diabetes Study } \\
\text { (UKPDS) }\end{array}$ & $\begin{array}{l}\text { To examine the effect of } \\
\text { tight blood pressure } \\
\text { control on morbidity } \\
\text { and mortality in patients } \\
\text { with type } 2 \text { diabetes and } \\
\text { hypertension }\end{array}$ & $\begin{array}{l}\text { Hypertensive } \\
\text { patients with type } \\
2 \text { diabetes } \\
\mathrm{n}=1,148\end{array}$ & $\begin{array}{l}\text { Randomized } \\
\text { controlled } \\
\text { trial }\end{array}$ & $\begin{array}{l}\text { Tight blood pressure control was } \\
\text { associated with a } 56 \% \text { reduction in } \\
\text { risk for heart failure compared to less } \\
\text { tight blood pressure control. }\end{array}$ \\
\hline $\begin{array}{l}\text { Hypertension } \\
\text { Optimal } \\
\text { Treatment } \\
\text { Trial (HOT) }\end{array}$ & $\begin{array}{l}\text { To investigate the } \\
\text { association between } \\
\text { cardiovascular events } \\
\text { and diastolic blood } \\
\text { pressures }\end{array}$ & $\begin{array}{l}\text { Adults aged } 50 \text { to } \\
80 \text { years of age } \\
\text { with hypertension } \\
\text { and diastolic blood } \\
\text { pressure between } \\
100 \mathrm{~mm} \mathrm{Hg} \text { and } \\
115 \mathrm{~mm} \mathrm{Hg} \\
\mathrm{n}=28,189\end{array}$ & $\begin{array}{l}\text { Randomized } \\
\text { controlled } \\
\text { trial }\end{array}$ & $\begin{array}{l}\text { Intensive blood pressure lowering to } \\
\text { diastolic blood pressure less than } 80 \\
\mathrm{~mm} \mathrm{Hg} \text { was associated with a two- } \\
\text { fold reduction in risk for all major } \\
\text { cardiovascular events compared } \\
\text { diastolic blood pressure lowering to } \\
90 \mathrm{~mm} \mathrm{Hg} \text {. }\end{array}$ \\
\hline
\end{tabular}


Table 2.4. (continued)

\begin{tabular}{|c|c|c|c|c|}
\hline Study & Objective & Sampling & $\begin{array}{c}\text { Study } \\
\text { Design }\end{array}$ & Major Findings \\
\hline $\begin{array}{l}\text { Systolic } \\
\text { Hypertension } \\
\text { in Europe Trial } \\
\text { (Syst-Eur) }^{44}\end{array}$ & $\begin{array}{l}\text { To determine if } \\
\text { nitrendipine had } \\
\text { different effects on } \\
\text { long-term complications } \\
\text { in diabetic and non- } \\
\text { diabetic individuals with } \\
\text { hypertension }\end{array}$ & $\begin{array}{l}\text { Adults aged } 60 \\
\text { years and older } \\
\text { with SBP between } \\
160 \text { and } 219 \mathrm{~mm} \\
\mathrm{Hg} \text { and } \mathrm{DBP}<95 \\
\mathrm{~mm} \mathrm{Hg} \\
\mathrm{n}=4,695\end{array}$ & $\begin{array}{l}\text { Post hoc } \\
\text { analysis }\end{array}$ & $\begin{array}{l}\text { In the diabetic group, treatment with } \\
\text { nitrendipine was associated with } \\
\text { significant reductions in overall } \\
\text { mortality, mortality from } \\
\text { cardiovascular causes, cardiovascular } \\
\text { events, stroke, and cardiac events. }\end{array}$ \\
\hline $\begin{array}{l}\text { Action in } \\
\text { Diabetes and } \\
\text { Vascular } \\
\text { Disease: } \\
\text { Preterax and } \\
\text { Diamicron MR } \\
\text { Controlled } \\
\text { Evaluation } \\
\text { (ADVANCE) }^{8}\end{array}$ & $\begin{array}{l}\text { To examine the effect of } \\
\text { a fixed combination of } \\
\text { perindopril and } \\
\text { indapamide on } \\
\text { macrovascular and } \\
\text { microvascular outcomes } \\
\text { in patients with type } 2 \\
\text { diabetes, irrespective of } \\
\text { initial blood pressure } \\
\text { level }\end{array}$ & $\begin{array}{l}\text { Adults with a } \\
\text { diagnosis of type } 2 \\
\text { diabetes at age } 30 \\
\text { years or older and } \\
\text { age } 55 \text { years or } \\
\text { older at study } \\
\text { enrollment } \\
\mathrm{n}=11,140\end{array}$ & $\begin{array}{l}\text { Randomized } \\
\text { controlled } \\
\text { trial }\end{array}$ & $\begin{array}{l}\text { Significantly fewer major } \\
\text { macrovascular or major } \\
\text { microvascular events occurred during } \\
\text { study follow-up for patients receiving } \\
\text { active treatment. Active treatment } \\
\text { was also associated with a significant } \\
21 \% \text { reduction in total renal events } \\
\text { and the development of } \\
\text { microalbuminuria. }\end{array}$ \\
\hline $\begin{array}{l}\text { ADVANCE: } \\
\text { Retinal } \\
\text { Measurements } \\
\text { Study } \\
(\text { AdRem) })^{45}\end{array}$ & $\begin{array}{l}\text { To examine the blood } \\
\text { pressure lowering on the } \\
\text { progression of } \\
\text { retinopathy in patients } \\
\text { with type } 2 \text { diabetes }\end{array}$ & $\begin{array}{l}\text { Adults with a } \\
\text { diagnosis of type } 2 \\
\text { diabetes at age } 30 \\
\text { years or older and } \\
\text { age } 55 \text { years or } \\
\text { older at study } \\
\text { enrollment }\end{array}$ & $\begin{array}{l}\text { Post hoc } \\
\text { analysis }\end{array}$ & $\begin{array}{l}\text { Active blood pressure lowering with } \\
\text { perindopril and indapamide was } \\
\text { associated with a significant } 50 \% \\
\text { reduction in macular edema and a } \\
40 \% \text { reduction arteriovenus nicking } \\
\text { compared to placebo. }\end{array}$ \\
\hline
\end{tabular}


Additionally, the rates of nonfatal myocardial infarction and fatal coronary heart disease and major coronary heart disease were significantly reduced in individuals with diabetes by $54 \%$ and $44 \%$, respectively. Five-year all-cause mortality was reduced by $26 \%$ in participants with diabetes. However, this reduction was not statistically significant.

\section{UK Prospective Diabetes Study (UKPDS)}

The hypertension in diabetes study was a randomized control trial that was embedded in the UKPDS. ${ }^{42}$ The hypertension in diabetes study sought to examine the effect of tight blood pressure control, defined as a blood pressure $<150 / 85 \mathrm{~mm} \mathrm{Hg}$, on morbidity and mortality in 1148 participants with type 2 diabetes and hypertension. The UKPDS group found a $56 \%$ reduction in risk in heart failure for those randomized to the tight control group compared to those randomized to the less tight blood pressure control group. Tight control was also associated with $24 \%, 32 \%$, and $37 \%$ reductions in risk in diabetes related endpoints, deaths due to diabetes, and microvascular complications, respectively. The UKPDS group also found that at nine years of follow-up, individuals in the tight blood pressure control group experienced a $34 \%$ reduction in risk in the proportion of individuals' retinopathy progressing by greater than two steps. Finally tight blood pressure control was significantly associated with a $47 \%$ reduction in the proportion of individuals' deterioration in vision. The hypertension in diabetes study did not find a significant reduction in risk for all-cause mortality. ${ }^{42}$

\section{Hypertension Optimal Treatment Trial (HOT)}

The HOT trial was a randomized control trial that investigated the association between cardiovascular events and diastolic blood pressures. Additionally the study sought to assess the relationship between diastolic blood pressure and various cardiovascular outcome measures. ${ }^{43}$ The HOT trial was conducted in adults aged 50 to 80 years of age with hypertension and a diastolic blood pressure between $100 \mathrm{~mm} \mathrm{Hg}$ and $115 \mathrm{~mm} \mathrm{Hg}$. Participants were then randomized to three target blood pressure levels: less than or equal to $90 \mathrm{~mm} \mathrm{Hg}$, less than or equal to $85 \mathrm{~mm} \mathrm{Hg}$, less than or equal to $80 \mathrm{~mm} \mathrm{Hg}$. ${ }^{43}$ The HOT study group categorized major cardiovascular events as all myocardial infarctions, all strokes, and all other cardiovascular events. ${ }^{43}$ Hansson et al found that intensive blood-pressure lowering to diastolic blood pressure less than $80 \mathrm{~mm} \mathrm{Hg}$ was associated with a two-fold reduction in risk for all major cardiovascular events compared to individuals randomized to diastolic blood pressure less than $90 \mathrm{~mm} \mathrm{Hg}$. The diastolic blood pressure found to be associated with the greatest reduction cardiovascular events was $82.6 \mathrm{~mm} \mathrm{Hg}^{43}$

\section{Systolic Hypertension in Europe Trial (Syst-Eur)}

The investigators of the Syst-Eur trial conducted a post-hoc analysis of the Syst-Eur data that sought to determine if nitrendipine, a dihydropyridine calcium channel blocker, had 
different effects on long-term complications in diabetic and non-diabetic individuals with hypertension. ${ }^{44}$ The outcomes examined in this post-hoc analysis were overall mortality, mortality from cardiovascular causes, cardiovascular events, stroke, and cardiac events. In the diabetic group, treatment with nitrendipine was associated with significant reductions in overall morality (55\%), mortality from cardiovascular causes $(76 \%)$, cardiovascular events (69\%), stroke (73\%), and cardiac events (67\%). In non-diabetic patients significant reductions were only seen in cardiovascular events $(26 \%)$ and stroke (38\%). Reductions in events were significantly greater in the diabetic group for overall mortality, mortality from cardiovascular causes, and cardiovascular events. ${ }^{44}$

\section{Action in Diabetes and Vascular Disease: Preterax and Diamicron MR Controlled Evaluation (ADVANCE)}

The ADVANCE trial was a randomized controlled trial conducted in 11,140 patients with type 2 diabetes. Additional inclusion criteria for study participation were diagnosis of type 2 diabetes at age 30 years or older and age 55 years or older at study enrollment. Participants were also required to have a history of major cardiovascular disease or at least one risk factor for cardiovascular disease. The study participants were randomized to fixed dose combination of perindopril and indapamide or matching placebo, including current therapy. ${ }^{8}$ The ADVANCE outcomes were major macrovascular (i.e., cardiovascular death, non-fatal myocardial infarction, non-fatal stroke) and microvascular events (i.e., new or worsening nephropathy, retinopathy). Secondary outcomes were allcause mortality, cardiovascular death, major coronary events (i.e., death due to coronary heart disease, nonfatal myocardial infarction), total coronary events, major cerebrovascular events, and total cerebrovascular events. ${ }^{8}$ The ADVANCE study group found that significantly fewer major macrovascular or major microvascular events occurred during study follow-up for study participants receiving active treatment. Additionally, the ADVANCE data indicated that over five years, one death in every 79 people being treated with the fixed dose perindopril-indapamide combination and one death due to coronary events in every 75 people on active treatment with the fixed dose combination would be avoided. Active treatment was also associated with a significant $21 \%$ reduction in total renal events and the development of microalbuminuria. ${ }^{8}$

\section{ADVANCE: Retinal Measurements Study (AdRem)}

The ADVANCE Retinal Measurements study, a substudy of the ADVANCE trial, investigated whether blood pressure lowering and glucose control would improve retinopathy outcomes. ${ }^{45}$ The study was conducted in adults who were age 55 years or older at study entry and had been diagnosed with type 2 diabetes for at least 25 years. ${ }^{45}$ Blood pressure lowering was achieved in the treatment group with combination perindopril and indapamide maximized to $4 \mathrm{mg}$ and $1.25 \mathrm{mg}$, respectively. Active blood pressure lowering with perindopril and indapamide was associated with a significant $50 \%$ reduction in macular edema and a $40 \%$ reduction in arteriovenus nicking compared to the placebo group. 
Though the aforementioned studies investigated different complications and outcomes associated with the presence of hypertension in patients with diabetes, the studies all indicate that the achievement of optimal blood pressure in individuals with diabetes results in significant reductions in morbidity and mortality. Therefore health care providers should work to achieve a blood pressure of less than 130/80 $\mathrm{mm} \mathrm{Hg}$ in patients with diabetes and concomitant hypertension.

\section{Relationship of Health Literacy and Health Outcomes}

Functional health literacy is the ability to read and comprehend health care related materials necessary to successfully navigate health care. ${ }^{22}$ An interesting characteristic of health literacy is that it is context specific. Therefore, an individual could have adequate functional health literacy with respect to their diabetes for which they are familiar with and have been managing for years, but could have inadequate functional health literacy with respect to a new diagnosis that consists of unfamiliar vocabulary and procedures. ${ }^{22,46}$ The tests mostly commonly used to asses health literacy are the Wide Range Achievement Test-Revised (WRAT-R), the Rapid Estimate of Adult Literacy in Medicine (REALM), Medical Terminology Achievement Reading Test (MART), Slosson Oral Reading Test-Revised (SORT-R), the Peabody Individual Achievement TestRevised (PIAT-R), Instrument for the Diagnosis of Reading (IDR), and the Test of Functional Health Literacy in Adults (TOFHLA). ${ }^{47}$ Table 2.5 highlights various attributes of the four instruments most commonly seen in the literature; REALM, SORTR, TOFHLA, and WRAT-R.

In 2003, the U.S. Department of Education, National Center for Education Statistics (NCES) conducted the National Assessment of Adult Literacy (NAAL). The NAAL was the first assessment of American literacy since the 1992 National Adult Literacy Survey, and it was the first time that health literacy was examined on a national level. ${ }^{2,48}$ Health literacy proficiency was divided into four categories: below basic, basic, intermediate, and proficient. ${ }^{48,49}$ The NCES found that approximately one-third of the American population has basic or below basic health literacy skills. Women were found to have an average health literacy score six points greater than men. More blacks, Hispanics, and multiracial adults were found to have basic and below basic health literacy skills compared to whites and Asians/Pacific Islanders. Additionally, individuals aged 65 years and older have the lowest health literacy abilities compared to all other age groups. ${ }^{48,49}$

Health literacy has been consistently linked to health outcomes in the literature. DeWalt et al conducted a literature review of 684 articles to determine the nature of the relationship between health literacy and health outcomes. ${ }^{50}$ Patients with low literacy were found to be 1.5 to 3 times more likely to have poorer outcomes, such as knowledge, intermediate disease state markers, measures of morbidity, general health status, and health care utilization, compared to their counterparts with adequate health literacy skills. ${ }^{50}$ In 2007 Paasche-Orlow et al further examined the relationship between health literacy and health outcomes by attempting to elucidate the causal pathways between the two entities. ${ }^{51}$ Paasche-Orlow et al proposed that the causal relationship between health 
Table 2.5. Commonly referenced health literacy instruments

\begin{tabular}{|c|c|c|c|c|c|}
\hline $\begin{array}{l}\text { Test Name } \\
\text { (Acronym) }\end{array}$ & $\begin{array}{l}\text { Aspect of } \\
\text { Literacy } \\
\text { Measured }\end{array}$ & Scale & $\begin{array}{c}\text { Time to } \\
\text { Administer }\end{array}$ & Advantages & Disadvantages \\
\hline $\begin{array}{l}\text { Rapid Estimate of } \\
\text { Adult Literacy } \\
\text { (REALM) - 66- } \\
\text { word version }^{50,53,54}\end{array}$ & $\begin{array}{l}\text { Pronunciation } \\
\text { of medical } \\
\text { terms }\end{array}$ & $\begin{array}{l}\leq 3^{\text {rd }} \text { grade, } 4^{\text {th }} \\
\text { to } 6^{\text {th }} \text { grade, } \\
7^{\text {th }} \text { to } 8^{\text {th }} \\
\text { grade, and } \geq \\
9^{\text {th }} \text { grade }\end{array}$ & $\begin{array}{l}2 \text { to } 3 \\
\text { minutes }\end{array}$ & $\begin{array}{l}\text { Uses health care } \\
\text { related terms, } \\
\text { quick to } \\
\text { administer, highly } \\
\text { correlated with } \\
\text { other reading tests }\end{array}$ & $\begin{array}{l}\text { Does not measure } \\
\text { reading } \\
\text { comprehension, does } \\
\text { not measure ability } \\
\text { above } 9^{\text {th }} \text { grade level, } \\
\text { not available in } \\
\text { Spanish }\end{array}$ \\
\hline $\begin{array}{l}\text { Slosson Oral } \\
\text { Reading Test - } \\
\text { Revised } \\
(\text { SORT-R) })^{50,53}\end{array}$ & Pronunciation & $\begin{array}{l}\text { Raw score; } \\
\text { grade } \\
\text { equivalents; } \\
\text { age } \\
\text { equivalents }\end{array}$ & $\begin{array}{l}5 \text { to } 10 \\
\text { minutes }\end{array}$ & $\begin{array}{l}\text { Can be used in } \\
\text { individuals aged } 4 \\
\text { years old and } \\
\text { older }\end{array}$ & $\begin{array}{l}\text { Small font unusable for } \\
\text { patients with poor visual } \\
\text { acuity, does not measure } \\
\text { reading comprehension }\end{array}$ \\
\hline $\begin{array}{l}\text { Test of Functional } \\
\text { Health Literacy in } \\
\text { Adults } \\
\text { (TOFHLA) }^{50,55,56}\end{array}$ & $\begin{array}{l}\text { Reading } \\
\text { comprehension } \\
\text { (prose literacy) } \\
\text { and numeracy }\end{array}$ & $\begin{array}{l}0-100 \\
\text { Inadequate, } \\
\text { marginal, and } \\
\text { adequate }\end{array}$ & $\begin{array}{l}\text { TOFHLA: } \\
22 \text { minutes } \\
\text { Short form } \\
\text { TOFHLA: } 7 \\
\text { minutes }\end{array}$ & $\begin{array}{l}\text { Uses health-care } \\
\text { related materials, } \\
\text { measures } \\
\text { comprehension, } \\
\text { good face } \\
\text { validity, available } \\
\text { in Spanish }\end{array}$ & $\begin{array}{l}\text { Lengthy administration, } \\
\text { hard to sort out } \\
\text { numeracy score from } \\
\text { comprehension score }\end{array}$ \\
\hline $\begin{array}{l}\text { Wide Range } \\
\text { Achievement Test - } \\
\text { Revised } \\
(\text { WRAT-R) } \\
\text { (W0,53 }\end{array}$ & $\begin{array}{l}\text { Reading } \\
\text { recognition, } \\
\text { spelling, and } \\
\text { arithmetic }\end{array}$ & $\begin{array}{l}3^{\text {rd }} \text { to } 12^{\text {th }} \\
\text { grade }\end{array}$ & $\begin{array}{l}3 \text { to } 5 \\
\text { minutes }\end{array}$ & $\begin{array}{l}\text { Standard, quick to } \\
\text { administer, well } \\
\text { validated and } \\
\text { studied }\end{array}$ & $\begin{array}{l}\text { Does not measure } \\
\text { reading comprehension, } \\
\text { not available in Spanish. }\end{array}$ \\
\hline
\end{tabular}


literacy and health outcomes is influenced by not only patient characteristics but also by characteristics of the health care system (i.e health care access and utilization, providerpatient interaction, and self-care). ${ }^{51}$ Within each of these three system attributes are patient and system factors, such as self-efficacy and complexity of the system, that prohibit individuals with low health literacy from practicing preventive health care activities and receiving timely acute and chronic care services, thus leading to poorer health outcomes. ${ }^{51}$ Table 2.6 summarizes articles investigating the relationship between health literacy and economic, clinical, and humanistic outcomes (ECHO).

\section{Hypertension Knowledge Instruments in the Literature}

Many studies that seek to assess an individual's hypertension knowledge do not utilize a validated hypertension knowledge instrument. Instead these studies assess a patient's disease state knowledge with questions that though are derived from the literature have not been validated as whole to work together to accurately measure hypertension knowledge. ${ }^{13-15,17-19,31,32,52}$ Currently in the literature there is only one hypertension knowledge instrument whose psychometric properties have been assessed. ${ }^{16}$ Peters and Templin not only developed and assessed the psychometric properties of a hypertension knowledge instrument but also of an instrument measuring the performance of self-care behaviors of individuals with hypertension. ${ }^{16}$ For the hypertension knowledge instrument, individuals were asked how likely they thought a particular activity would control their blood pressure. These questions were associated with a seven-point Likert scale anchored by the options "extremely unlikely" and "extremely likely." The hypertension self-care instrument consisted of asking respondents how often they perform a particular self-care behavior with answers ranging from "never" to "always." 16

Even though Peters and Templin's scale exhibited acceptable validity (Cronbach's alpha $=0.90$ ), there were limitations associated with its development. First, the Peters and Templin's blood pressure knowledge scale asked respondents how likely they believe that a self-care behavior would control their blood pressure. This type of question does not address knowledge but rather addresses outcome expectancy. Outcome expectancy is the belief that the engagement in a certain self-care behaviors will lead to an improvement in a health condition. ${ }^{85}$ Given this definition, Peters and Templin's hypertension knowledge scale gives an idea of an individual's intention to perform behavior but does not assess whether the individual knows the correct behavior in which to engage. Additionally, both of Peters and Templin's scales were developed for an African American population. Though this is not a limitation per se, it does limit the validity of the scale in other ethnic populations. The authors also note in their work that the questions were written with African American cultural influences in mind. Therefore, the wording of the questions could be interpreted and answered differently depending on the cultural background of the respondent. The hypertension knowledge instrument for this study was developed with the limitations of the Peters and Templin scale in mind. 
Table 2.6. Studies evaluating relationship between health literacy and ECHO

\begin{tabular}{llclc}
\hline Source & Objective & Sampling & Study Design & $\begin{array}{c}\text { Health } \\
\text { Literacy } \\
\text { Instrument }\end{array}$ \\
\hline
\end{tabular}

\section{Economic and Humanistic}

\begin{tabular}{|c|c|c|c|c|c|}
\hline $\begin{array}{l}\text { Baker et } \\
\mathrm{al}^{57}\end{array}$ & $\begin{array}{l}\text { To investigate } \\
\text { the relationship } \\
\text { between health } \\
\text { literacy and self- } \\
\text { reported health } \\
\text { and use of health } \\
\text { services }\end{array}$ & $\begin{array}{l}\text { English and } \\
\text { Spanish- } \\
\text { speaking } \\
\text { adults } \\
\mathrm{n}=2,659\end{array}$ & Cross-sectional & TOFHLA & $\begin{array}{l}\text { Patients with inadequate } \\
\text { health literacy were more } \\
\text { likely to report poor health } \\
\text { status and to report being } \\
\text { hospitalized in the previous } \\
\text { year compared to those with } \\
\text { adequate health literacy. }\end{array}$ \\
\hline $\begin{array}{l}\text { Baker et } \\
\mathrm{al}^{58}\end{array}$ & $\begin{array}{l}\text { To determine the } \\
\text { association } \\
\text { between health } \\
\text { literacy and risk } \\
\text { of hospitalization }\end{array}$ & $\begin{array}{l}\text { Adults aged } \\
18 y e a r s \text { and } \\
\text { older with } \\
\text { English as the } \\
\text { primary } \\
\text { language } \\
\mathrm{n}=958\end{array}$ & Prospective & TOFHLA & $\begin{array}{l}\text { Patients with inadequate } \\
\text { health literacy were more } \\
\text { likely to have been } \\
\text { hospitalized at least once } \\
\text { between } 1994-1995 \\
\text { compared to those with } \\
\text { marginal or adequate health } \\
\text { literacy. }\end{array}$ \\
\hline $\begin{array}{l}\text { Baker et } \\
\mathrm{al}^{59}\end{array}$ & $\begin{array}{l}\text { To explore the } \\
\text { relationship } \\
\text { between health } \\
\text { literacy and the } \\
\text { risk of hospital } \\
\text { admission } \\
\text { among Medicare } \\
\text { enrollees }\end{array}$ & $\begin{array}{l}\text { New Medicare } \\
\text { enrollees aged } \\
65 \text { years and } \\
\text { older who } \\
\text { were English } \\
\text { or Spanish } \\
\text { speaking } \\
n=3,260\end{array}$ & Prospective & TOFHLA & $\begin{array}{l}\text { Patients with inadequate } \\
\text { health literacy were more } \\
\text { likely to report poor health } \\
\text { status than those with } \\
\text { adequate health literacy and } \\
\text { were more likely to be } \\
\text { hospitalized. }\end{array}$ \\
\hline
\end{tabular}


Table 2.6. (continued)

\begin{tabular}{|c|c|c|c|c|c|}
\hline Source & Objective & Sampling & Study Design & $\begin{array}{c}\text { Health } \\
\text { Literacy } \\
\text { Instrument }\end{array}$ & Major Findings \\
\hline 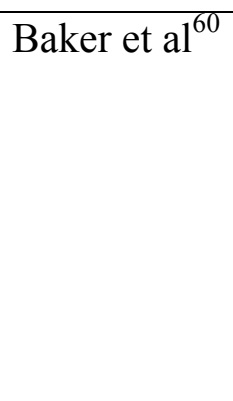 & $\begin{array}{l}\text { To determine } \\
\text { whether low } \\
\text { health literacy } \\
\text { adversely affects } \\
\text { use of physician } \\
\text { outpatient } \\
\text { services }\end{array}$ & $\begin{array}{l}\text { Medicare } \\
\text { enrollees } \\
\text { aged } 65 \\
\text { years and } \\
\text { older } \\
\mathrm{n}=3,260\end{array}$ & Retrospective & S-TOFHLA & $\begin{array}{l}\text { Patients with inadequate } \\
\text { health literacy are more likely } \\
\text { to have an emergency } \\
\text { department visit. Health } \\
\text { literacy was not associated } \\
\text { with mean number of } \\
\text { outpatient visits or time to } \\
\text { first visit. }\end{array}$ \\
\hline Scott et $\mathrm{al}^{61}$ & $\begin{array}{l}\text { To determine } \\
\text { whether } \\
\text { Medicare } \\
\text { enrollees with } \\
\text { inadequate } \\
\text { health literacy } \\
\text { were less likely } \\
\text { to utilize } \\
\text { preventive health } \\
\text { care services }\end{array}$ & $\begin{array}{l}\text { English or } \\
\text { Spanish- } \\
\text { speaking } \\
\text { Medicare } \\
\text { enrollees } \\
\text { aged } 65-79 \\
\text { years } \\
\mathrm{n}=2,722\end{array}$ & Prospective & S-TOFHLA & $\begin{array}{l}\text { Lack of preventive health } \\
\text { care service utilization was } \\
\text { higher among those with } \\
\text { inadequate health literacy. }\end{array}$ \\
\hline Weiss et $\mathrm{al}^{62}$ & $\begin{array}{l}\text { To determine } \\
\text { whether low } \\
\text { literacy is } \\
\text { associated with } \\
\text { increased health } \\
\text { care charges }\end{array}$ & $\begin{array}{l}\text { English or } \\
\text { Spanish- } \\
\text { speaking } \\
\text { adult } \\
\text { Medicaid } \\
\text { enrollees } \\
\mathrm{n}=74\end{array}$ & Retrospective & IDR & $\begin{array}{l}\text { Limited literacy was } \\
\text { associated with increased } \\
\text { health care charges compared } \\
\text { to those with adequate } \\
\text { literacy skills. }\end{array}$ \\
\hline
\end{tabular}


Table 2.6. (continued)

\begin{tabular}{ccccc}
\hline Source & Objective & Sampling & Study Design & $\begin{array}{c}\text { Health } \\
\text { Literacy } \\
\text { Instrument }\end{array}$ \\
\hline
\end{tabular}

\section{Diabetes}

Endres et $\mathrm{al}^{63}$

the association

between

functional health

literacy and

pregnancy

preparedness in

women with

pregestational

diabetes

Grubbs et al ${ }^{64} \quad$ To examine the relationship between health

literacy and access to the

kidney transplant

wait-list

Morris et $\mathrm{al}^{65} \quad$ To determine the association between literacy and various

health outcomes

in adults with

diabetes
English and

Spanish-

speaking

pregnant

women with

pregestational

diabetes

$\mathrm{n}=74$

Non-Hispanic Retrospective

blacks and

whites aged

21 to 75

years

$n=62$

English-

speaking

adults with

diabetes

$\mathrm{n}=1,002$
Cross-sectional

S-TOFHLA

Women with inadequate

health literacy more likely

to have unplanned

pregnancy and less likely to

have discussed pregnancy

ahead of time with an

endocrinologist or

obstetrician or taken folic acid.

S-TOFHLA

Patients with inadequate health literacy were $78 \%$ less likely to receive transplant evaluation than those with adequate health literacy.

Cross-sectional

S-TOFHLA

No significant association between health literacy and health outcomes or diabetes complications was found. 
Table 2.6. (continued)

\begin{tabular}{|c|c|c|c|c|c|}
\hline Source & Objective & Sampling & Study Design & $\begin{array}{c}\text { Health } \\
\text { Literacy } \\
\text { Instrument }\end{array}$ & Major Findings \\
\hline Rothman et al ${ }^{66}$ & $\begin{array}{l}\text { To investigate the } \\
\text { role of literacy in } \\
\text { patients with } \\
\text { poorly controlled } \\
\text { diabetes }\end{array}$ & $\begin{array}{l}\text { Adult patients } \\
\text { with type } 2 \\
\text { diabetes and } \\
\text { HbA1c } \geq 8.0 \% \\
\mathrm{n}=159\end{array}$ & Prospective & REALM & $\begin{array}{l}\text { Health literacy was not a } \\
\text { significant predictor of } \\
\text { improvement in HbAlc } \\
\text { levels of patients with } \\
\text { type } 2 \text { diabetes. }\end{array}$ \\
\hline Schillinger et $\mathrm{al}^{67}$ & $\begin{array}{l}\text { To examine the } \\
\text { relationship } \\
\text { between health } \\
\text { literacy and } \\
\text { diabetes } \\
\text { outcomes among } \\
\text { patients with type } \\
2 \text { diabetes }\end{array}$ & $\begin{array}{l}\text { English and } \\
\text { Spanish- } \\
\text { speaking adults } \\
\text { aged } 30 \text { years } \\
\text { and older with } \\
\text { type } 2 \text { diabetes } \\
\mathrm{n}=408\end{array}$ & Cross-sectional & S-TOFHLA & $\begin{array}{l}\text { For each } 1 \text { point } \\
\text { decrease in S-TOFHLA, } \\
\text { the HbAlc increased by } \\
0.02 \text {. Patients with } \\
\text { inadequate health } \\
\text { literacy were less likely } \\
\text { to have tight glycemic } \\
\text { control and were more } \\
\text { likely to have poor } \\
\text { glycemic control than } \\
\text { those with adequate } \\
\text { health literacy. }\end{array}$ \\
\hline Schillinger et $\mathrm{al}^{68}$ & $\begin{array}{l}\text { To determine } \\
\text { whether health } \\
\text { literacy mediates } \\
\text { the literacy } \\
\text { between } \\
\text { education and } \\
\text { health outcomes } \\
\text { in patients with } \\
\text { diabetes }\end{array}$ & $\begin{array}{l}\text { English and } \\
\text { Spanish- } \\
\text { speaking adults } \\
\text { aged } 30 \text { years } \\
\text { and older with } \\
\text { type } 2 \text { diabetes } \\
\mathrm{n}=395\end{array}$ & Cross-sectional & S-TOFHLA & $\begin{array}{l}\text { Literacy mediated the } \\
\text { relationship between } \\
\text { education and health } \\
\text { outcomes. }\end{array}$ \\
\hline
\end{tabular}


Table 2.6. (continued)

\begin{tabular}{|c|c|c|c|c|c|}
\hline Source & Objective & Sampling & Study Design & $\begin{array}{c}\text { Health } \\
\text { Literacy } \\
\text { Instrument }\end{array}$ & Major Findings \\
\hline Tang et $\mathrm{al}^{69}$ & $\begin{array}{l}\text { To examine the } \\
\text { relationship } \\
\text { between health } \\
\text { literacy and } \\
\text { diabetic control in } \\
\text { patients with type } 2 \\
\text { diabetes }\end{array}$ & $\begin{array}{l}\text { Chinese adults } \\
\text { aged } 18 \text { years and } \\
\text { older with type } 2 \\
\text { diabetes } \\
\mathrm{n}=149\end{array}$ & Descriptive & $\begin{array}{l}\text { S-TOFHLA } \\
\text { translated } \\
\text { into } \\
\text { Chinese }\end{array}$ & $\begin{array}{l}\text { Increased health } \\
\text { literacy was associated } \\
\text { with decreased HbAlc. }\end{array}$ \\
\hline \multicolumn{6}{|l|}{ Asthma } \\
\hline Mancuso et a ${ }^{70}$ & $\begin{array}{l}\text { To determine the } \\
\text { association } \\
\text { between health } \\
\text { literacy and } \\
\text { longitudinal } \\
\text { outcomes in } \\
\text { patients with } \\
\text { asthma }\end{array}$ & $\begin{array}{l}\text { English-speaking } \\
\text { adults with } \\
\text { asthma } \\
\mathrm{n}=175\end{array}$ & Prospective & TOFHLA & $\begin{array}{l}\text { Less health literacy } \\
\text { was associated with } \\
\text { worse quality of life, } \\
\text { worse physical } \\
\text { function, and having } \\
\text { been treated for asthma } \\
\text { in the emergency } \\
\text { department during the } \\
\text { study period. }\end{array}$ \\
\hline Williams et a ${ }^{71}$ & $\begin{array}{l}\text { To assess the } \\
\text { relationship } \\
\text { between health } \\
\text { literacy and asthma } \\
\text { knowledge and the } \\
\text { ability to use a } \\
\text { metered dose } \\
\text { inhaler }\end{array}$ & $\begin{array}{l}\text { English-speaking } \\
\text { adults aged } 18 \\
\text { years and older } \\
\text { with a }>3 \text { month } \\
\text { history of asthma } \\
\text { and no diagnosis } \\
\text { of COPD } \\
n=273\end{array}$ & Cross-sectional & REALM & $\begin{array}{l}\text { Low health literacy } \\
\text { was associated with } \\
\text { poorer knowledge and } \\
\text { improper metered dose } \\
\text { inhaler technique. }\end{array}$ \\
\hline
\end{tabular}


Table 2.6. (continued)

\begin{tabular}{|c|c|c|c|c|c|}
\hline Source & Objective & Sampling & Study Design & $\begin{array}{c}\text { Health } \\
\text { Literacy } \\
\text { Instrument }\end{array}$ & Major Findings \\
\hline \multicolumn{6}{|l|}{ Mental Health } \\
\hline Gazmararian et al ${ }^{72}$ & $\begin{array}{l}\text { To determine } \\
\text { whether older } \\
\text { adults with } \\
\text { inadequate health } \\
\text { literacy are more } \\
\text { likely to report } \\
\text { depressive } \\
\text { symptoms }\end{array}$ & $\begin{array}{l}\text { English or } \\
\text { Spanish- } \\
\text { speaking adult } \\
\text { new Medicare } \\
\text { enrollees aged } \\
65 \text { years and } \\
\text { older } \\
n=3,171\end{array}$ & Prospective & S-TOFHLA & $\begin{array}{l}\text { After controlling for } \\
\text { health status, individuals } \\
\text { with inadequate health } \\
\text { literacy were not more } \\
\text { likely to be depressed. }\end{array}$ \\
\hline Lincoln et $\mathrm{al}^{73}$ & $\begin{array}{l}\text { To examine the } \\
\text { relationship } \\
\text { between health } \\
\text { literacy, addiction } \\
\text { severity, } \\
\text { depressive } \\
\text { symptoms, and } \\
\text { mental health } \\
\text { functioning } \\
\text { among people } \\
\text { with drug and } \\
\text { alcohol } \\
\text { dependence }\end{array}$ & $\begin{array}{l}\text { English or } \\
\text { Spanish- } \\
\text { speaking } \\
\text { individuals older } \\
\text { than } 17 \text { years } \\
\text { who report } \\
\text { alcohol, heroine, } \\
\text { or cocaine as } \\
\text { substance of } \\
\text { first choice } \\
\mathrm{n}=380\end{array}$ & Prospective & REALM & $\begin{array}{l}\text { Lower health literacy } \\
\text { was associated with } \\
\text { higher depressive } \\
\text { symptoms. Lower } \\
\text { health literacy was not } \\
\text { associated with } \\
\text { addiction severity or } \\
\text { mental health related } \\
\text { quality of life. }\end{array}$ \\
\hline
\end{tabular}


Table 2.6. (continued)

\begin{tabular}{|c|c|c|c|c|c|}
\hline Source & Objective & Sampling & Study Design & $\begin{array}{c}\text { Health } \\
\text { Literacy } \\
\text { Instrument }\end{array}$ & Major Findings \\
\hline \multicolumn{6}{|c|}{ Sexually Transmitted Diseases } \\
\hline Barragan et $\mathrm{al}^{74}$ & $\begin{array}{l}\text { To determine the } \\
\text { relationship } \\
\text { between health } \\
\text { literacy and } \\
\text { acceptance of } \\
\text { HIV testing }\end{array}$ & $\begin{array}{l}\text { English- } \\
\text { speaking adults } \\
\text { aged } 18 \text { to } 65 \\
\text { years not } \\
\text { known to be } \\
\text { HIV positive } \\
n=372\end{array}$ & Cross-sectional & REALM & $\begin{array}{l}\text { Patients with low health } \\
\text { literacy were more } \\
\text { likely to get HIV testing } \\
\text { if recommended by a } \\
\text { health care provider } \\
\text { than those with } \\
\text { adequate health literacy. }\end{array}$ \\
\hline $\begin{array}{l}\text { Fortenberry et } \\
\mathrm{al}^{75}\end{array}$ & $\begin{array}{l}\text { To examine the } \\
\text { relationship } \\
\text { between health } \\
\text { literacy and the } \\
\text { receipt of a } \\
\text { gonorrhea } \\
\text { screening test }\end{array}$ & $\begin{array}{l}\text { Individuals } \\
\text { aged } 12 \text { to } 55 \\
\text { years } \\
\mathrm{n}=890\end{array}$ & Cross-sectional & REALM & $\begin{array}{l}\text { Increased health literacy } \\
\text { was associated with } \\
\text { greater odds of having } \\
\text { had a gonorrhea test in } \\
\text { the past year. }\end{array}$ \\
\hline Kalichman et $\mathrm{al}^{76}$ & $\begin{array}{l}\text { To determine } \\
\text { whether health } \\
\text { literacy is } \\
\text { associated with } \\
\text { health status and } \\
\text { health-related } \\
\text { knowledge in } \\
\text { people living } \\
\text { with HIV-AIDS }\end{array}$ & $\begin{array}{l}\text { English- } \\
\text { speaking adult } \\
\text { men and } \\
\text { women infected } \\
\text { with HIV } \\
\mathrm{n}=339\end{array}$ & Cross-sectional & TOFHLA & $\begin{array}{l}\text { Lower health literacy } \\
\text { was associated with } \\
\text { lower CD4 counts, } \\
\text { higher viral loads, lower } \\
\text { likelihood to be taking } \\
\text { antiretrovirals, } \\
\text { increased } \\
\text { hospitalizations, and } \\
\text { poorer self-reported } \\
\text { health status. }\end{array}$ \\
\hline
\end{tabular}


Table 2.6. (continued)

\begin{tabular}{|c|c|c|c|c|c|}
\hline Source & Objective & Sampling & Study Design & $\begin{array}{c}\text { Health } \\
\text { Literacy } \\
\text { Instrument }\end{array}$ & Major Findings \\
\hline Nokes et $\mathrm{al}^{77}$ & $\begin{array}{l}\text { To determine } \\
\text { the impact of } \\
\text { health literacy } \\
\text { on body change } \\
\text { distress, } \\
\text { depressive } \\
\text { symptoms, and } \\
\text { HIV symptom } \\
\text { intensity in } \\
\text { persons living } \\
\text { with HIV-AIDS }\end{array}$ & $\begin{array}{l}\text { Community- } \\
\text { dwelling, } \\
\text { English- } \\
\text { speaking } \\
\text { adults known } \\
\text { to be HIV } \\
\text { positive } \\
\mathrm{n}=489\end{array}$ & Cross-sectional & REALM & $\begin{array}{l}\text { Lower health literacy } \\
\text { was associated with } \\
\text { increased reported } \\
\text { body change distress, } \\
\text { more depressive } \\
\text { symptoms, and } \\
\text { increased HIV } \\
\text { symptom intensity. }\end{array}$ \\
\hline Paasche-Orlow et al ${ }^{78}$ & $\begin{array}{l}\text { To determine } \\
\text { whether low } \\
\text { health literacy is } \\
\text { associated with } \\
\text { worse adherence } \\
\text { to antiretroviral } \\
\text { therapy and less } \\
\text { frequent viral } \\
\text { load suppression }\end{array}$ & $\begin{array}{l}\text { English or } \\
\text { Spanish- } \\
\text { speaking } \\
\text { adults with } \\
\text { HIV who } \\
\text { answered at } \\
\text { least two } \\
\text { CAGE } \\
\text { questions } \\
\text { positively } \\
\mathrm{n}=235\end{array}$ & Prospective & REALM & $\begin{array}{l}\text { Lower health literacy } \\
\text { was associated with } \\
\text { increased adherence } \\
\text { and more frequent } \\
\text { virologic suppression. }\end{array}$ \\
\hline
\end{tabular}


Table 2.6. (continued)

\begin{tabular}{|c|c|c|c|c|c|}
\hline Source & Objective & Sampling & Study Design & $\begin{array}{c}\text { Health } \\
\text { Literacy } \\
\text { Instrument }\end{array}$ & Major Findings \\
\hline \multicolumn{6}{|l|}{ Elderly } \\
\hline Baker et $\mathrm{al}^{79}$ & $\begin{array}{l}\text { To determine } \\
\text { whether low } \\
\text { literacy is } \\
\text { associated with } \\
\text { overall and cause- } \\
\text { specific mortality }\end{array}$ & $\begin{array}{l}\text { New Medicare } \\
\text { enrollees aged } \\
65 \text { years and } \\
\text { older } \\
n=3,260\end{array}$ & Prospective & TOFHLA & $\begin{array}{l}\text { Enrollees with inadequate } \\
\text { or marginal health literacy } \\
\text { were more likely to die } \\
\text { than those with adequate } \\
\text { health literacy. }\end{array}$ \\
\hline Sudore et $\mathrm{al}^{80}$ & $\begin{array}{l}\text { To assess the } \\
\text { relationship } \\
\text { between limited } \\
\text { literacy and } \\
\text { mortality }\end{array}$ & $\begin{array}{l}\text { Black and white } \\
\text { Medicare men } \\
\text { and women aged } \\
70-79 \text { years } \\
\mathrm{n}=2,512\end{array}$ & Prospective & REALM & $\begin{array}{l}\text { Enrollees with inadequate } \\
\text { health literacy had higher } \\
\text { all-cause mortality than } \\
\text { those with adequate health } \\
\text { literacy. }\end{array}$ \\
\hline Wolf et al ${ }^{79}$ & $\begin{array}{l}\text { To determine the } \\
\text { association } \\
\text { between health } \\
\text { literacy, physical } \\
\text { and mental health } \\
\text { functioning, and } \\
\text { health related } \\
\text { activity limitations }\end{array}$ & $\begin{array}{l}\text { English or } \\
\text { Spanish- } \\
\text { speaking new } \\
\text { Medicare } \\
\text { enrollees aged } \\
65 \text { years and } \\
\text { older } \\
\mathrm{n}=2,923\end{array}$ & Cross-sectional & TOFHLA & $\begin{array}{l}\text { Enrollees with inadequate } \\
\text { health literacy had worse } \\
\text { physical functioning and } \\
\text { mental health. Enrollees } \\
\text { with inadequate health } \\
\text { literacy had higher rates of } \\
\text { hypertension, diabetes, } \\
\text { heart failure, and arthritis. }\end{array}$ \\
\hline
\end{tabular}


Table 2.6. (continued)

\begin{tabular}{|c|c|c|c|c|c|}
\hline Source & Objective & Sampling & Study Design & $\begin{array}{c}\text { Health } \\
\text { Literacy } \\
\text { Instrument }\end{array}$ & Major Findings \\
\hline
\end{tabular}

\section{Anticoagulation}

$\begin{array}{lll}\text { Fang et al }^{81} & \begin{array}{l}\text { To determine } \\ \text { whether health }\end{array} & \text { English, } \\ \text { literacy is associated } & \text { Spanish, or } \\ \text { Cantonese- } & \text { speaking adults } \\ \text { knowledge, } & \text { aged 18 years } \\ \text { adherence, and } & \text { and older who } \\ \text { warfarin control } & \text { had been taking } \\ & \text { warfarin } \\ & \text { continuously for } \\ & 3 \text { months } \\ & \mathrm{n}=179\end{array}$

Cross-sectional S-TOFHLA Limited health literacy was associated with decreased warfarinrelated knowledge. Limited literacy was not associated with adherence or time within therapeutic INR range.

\section{Cancer}

\begin{tabular}{|c|c|c|c|c|c|}
\hline Lindau et $\mathrm{al}^{82}$ & $\begin{array}{l}\text { To determine } \\
\text { whether health } \\
\text { literacy is predictive } \\
\text { of adherence to } \\
\text { cervical cancer } \\
\text { screenings }\end{array}$ & $\begin{array}{l}\text { English- } \\
\text { speaking } \\
\text { women with } \\
\text { abnormal pap } \\
\text { smears aged } 18 \\
\text { years and older } \\
\mathrm{n}=68\end{array}$ & Prospective & REALM & $\begin{array}{l}\text { Women perceived by } \\
\text { their physician to have } \\
\text { low literacy were less } \\
\text { likely to adhere to } \\
\text { cervical cancer } \\
\text { screening follow-ups. }\end{array}$ \\
\hline
\end{tabular}


Table 2.6. (continued)

\begin{tabular}{|c|c|c|c|c|c|}
\hline Source & Objective & Sampling & Study Design & $\begin{array}{c}\text { Health } \\
\text { Literacy } \\
\text { Instrument }\end{array}$ & Major Findings \\
\hline Miller et $\mathrm{al}^{83}$ & $\begin{array}{l}\text { To determine whether } \\
\text { low literacy affects a } \\
\text { patients knowledge or } \\
\text { receipt of colorectal } \\
\text { cancer screening }\end{array}$ & $\begin{array}{l}\text { English- } \\
\text { speaking adults } \\
\text { aged } 50 \text { years } \\
\text { and older } \\
\mathrm{n}=50\end{array}$ & Cross-sectional & REALM & $\begin{array}{l}\text { Low literacy did } \\
\text { not affect receipt of } \\
\text { colorectal cancer } \\
\text { screening. }\end{array}$ \\
\hline Peterson et $\mathrm{al}^{84}$ & $\begin{array}{l}\text { To determine if health } \\
\text { literacy is associated } \\
\text { with knowledge of } \\
\text { colorectal cancer and } \\
\text { screening tests, } \\
\text { perceived risks and } \\
\text { benefits of colorectal } \\
\text { cancer screening tests, } \\
\text { perceived risk of } \\
\text { colorectal screening, } \\
\text { self-efficacy for } \\
\text { completing screening } \\
\text { tests, and receipt of } \\
\text { colorectal cancer } \\
\text { screening tests }\end{array}$ & $\begin{array}{l}\text { English- } \\
\text { speaking } \\
\text { Tenncare or } \\
\text { Medicare } \\
\text { enrollees aged } \\
50 \text { years and } \\
\text { older } \\
\mathrm{n}=99\end{array}$ & Cross-sectional & REALM & $\begin{array}{l}\text { Limited health } \\
\text { literacy was } \\
\text { associated with } \\
\text { report of more } \\
\text { barriers to the } \\
\text { receipt of fecal } \\
\text { occult blood test } \\
\text { and colonoscopy. }\end{array}$ \\
\hline
\end{tabular}


Table 2.6. (continued)

\begin{tabular}{|c|c|c|c|c|c|}
\hline Source & Objective & Sampling & Study Design & $\begin{array}{c}\text { Health } \\
\text { Literacy } \\
\text { Instrument }\end{array}$ & Major Findings \\
\hline \multicolumn{6}{|l|}{ Cardiovascular } \\
\hline Gazmararian et $\mathrm{al}^{31}$ & $\begin{array}{l}\text { To examine the } \\
\text { relationship } \\
\text { between health } \\
\text { literacy and } \\
\text { disease state } \\
\text { knowledge }\end{array}$ & $\begin{array}{l}\text { Medicare } \\
\text { enrollees } \\
n=214\end{array}$ & Cross-sectional & S-TOFHLA & $\begin{array}{l}\text { Mean hypertension } \\
\text { knowledge scores were } \\
\text { lower for those with } \\
\text { inadequate health } \\
\text { literacy compared to } \\
\text { those with adequate } \\
\text { health literacy skills. }\end{array}$ \\
\hline Pandit et $\mathrm{al}^{52}$ & $\begin{array}{l}\text { To determine } \\
\text { whether health } \\
\text { literacy mediates } \\
\text { the relationship } \\
\text { between } \\
\text { education, } \\
\text { hypertension } \\
\text { knowledge, and } \\
\text { hypertension } \\
\text { control }\end{array}$ & $\begin{array}{l}\text { English- } \\
\text { speaking } \\
\text { adults aged } \\
18 \text { years and } \\
\text { older with a } \\
\text { diagnosis of } \\
\text { hypertension } \\
n=330\end{array}$ & Cross-sectional & S-TOFHLA & $\begin{array}{l}\text { Limited health literacy } \\
\text { was associated with } \\
\text { decreased hypertension } \\
\text { knowledge. Patients } \\
\text { with lower literacy } \\
\text { were less likely to have } \\
\text { control of their blood } \\
\text { pressure. Health } \\
\text { literacy did mediate the } \\
\text { relationship between } \\
\text { health literacy and } \\
\text { hypertension control } \\
\text { but did not reduce the } \\
\text { association to } \\
\text { nonsignificant. }\end{array}$ \\
\hline
\end{tabular}


Table 2.6. (continued)

\begin{tabular}{|c|c|c|c|c|c|}
\hline Source & Objective & Sampling & Study Design & $\begin{array}{c}\text { Health } \\
\text { Literacy } \\
\text { Instrument }\end{array}$ & Major Findings \\
\hline Williams et $\mathrm{al}^{32}$ & $\begin{array}{l}\text { To examine the } \\
\text { relationship between } \\
\text { health literacy and } \\
\text { knowledge of chronic } \\
\text { disease and the } \\
\text { treatment of chronic } \\
\text { disease }\end{array}$ & $\begin{array}{l}\text { English or } \\
\text { Spanish- } \\
\text { speaking } \\
\text { adults aged } \\
18 \text { years and } \\
\text { older with } \\
\text { diabetes or } \\
\text { hypertension } \\
\mathrm{n}=402\end{array}$ & Cross-sectional & TOFHLA & $\begin{array}{l}\text { Patients with } \\
\text { inadequate health } \\
\text { literacy were less likely } \\
\text { to answer a } \\
\text { hypertension } \\
\text { knowledge question } \\
\text { correctly compared to } \\
\text { those with adequate } \\
\text { health literacy. Blood } \\
\text { pressure control was } \\
\text { not associated with } \\
\text { health literacy. }\end{array}$ \\
\hline
\end{tabular}

Notes: ECHO indicates economic, humanistic, and clinical outcomes; HbA1c, hemoglobin A1c; IDR, Instrument for the Diagnosis of Reading; INR, international normalized ratio; REALM, Rapid Estimate of Adult Literacy in Medicine; TOFHLA, Test of Functional Health Literacy in Adults; S-TOFHLA, short form Test of Functional Health Literacy in Adults. 


\section{Relationship of Hypertension Knowledge and Hypertension Outcomes}

Many studies have examined the relationship between hypertension knowledge and other factors such as education, awareness, attitude, and health literacy. ${ }^{13-15,17-19,31,32,52}$

Unfortunately, no study has investigated the relationship between hypertension knowledge and outcomes. The ITHBC purports that not only do an individual's beliefs about a disease affect their willingness and ability to engage in self-care behaviors, but knowledge about the disease state and the self-care behaviors associated with the disease are also important factors in self-care behavior engagement and ultimately improvement in hypertension outcomes. ${ }^{20}$ However, more work needs to be done to further understand the relationship between hypertension knowledge and outcomes. 


\section{Chapter 3. Methodology}

The primary purpose of the study was to develop and validate an instrument that assesses the knowledge required of an individual to successfully manage his/her hypertension. In order to achieve this purpose a two-part cross-sectional study modeled after instrument

development and validation studies by Schaffer et al and Gourley et al was used. ${ }^{86,87}$ The secondary purpose of the study was to determine the association between scores on the hypertension knowledge instrument and various outcomes and complications of hypertension.

\section{Research Design}

\section{Phase One}

The study's phase one purpose was to assess the content validity of the instrument. Therefore, the instrument was provided to five experts in the areas of the treatment of hypertension, patient education with respect to chronic disease states, and instrument construction. The experts evaluated each item for succinctness, relevance, and readability. Instrument items were deleted or rewritten based on the experts' evaluations of the initial instrument.

\section{Phase Two}

A convenience sample of 200 hypertensive subjects was recruited to refine the initial instrument. These initial subjects were asked to complete the demographic, medical, and social history questions along with the S-TOFHLA and the hypertension knowledge instrument. An item analysis was performed to calculate the difficulty and variance of the questions comprising the hypertension knowledge instrument. Additionally, an item analysis was performed to determine the item-total correlation of the hypertension knowledge instrument questions. Items with negative item-total correlations (measuring a different construct than the other items) or close to zero item-total correlations (no relationship between the item and the remaining items) were considered for removal from the instrument. ${ }^{88}$ Internal consistency was assessed using the Kuder-Richardson formula 20 (KR-20) on the initial hypertension knowledge instrument and the refined instrument. ${ }^{88}$ In addition to the KR-20, the 95\% confidence interval for the KR-20 was determined. Exploratory factor analysis (EFA) with varimax rotation was performed to aid in the refinement of the initial hypertension knowledge instrument and to identify the number of factors or components in the final hypertension knowledge instrument. Confirmatory factor analysis (CFA) was used to test the factor structure identified in the EFA. $^{88}$ 


\section{Settings and Subjects}

\section{Study Setting}

The data were collected at a family medicine clinic associated with a southeastern United States health science center and a private hospital. The clinic focused on serving health needs that ranged from newborn care to preventive and chronic disease care. Patient care was provided by board-certified physicians, nurse practitioners, pharmacists, and resident physicians. $^{89}$

\section{Sampling Plan}

The study sample was drawn as a convenience sample of patients at the family medicine clinic. The investigator chose this method due to the limitations of study time and resources.

\section{Subject Inclusion Criteria}

The inclusion criteria for the study were the following: (1) 18 years of age and older, (2) diagnosis of hypertension (ICD-9 codes 401-essential hypertension, 402-hypertensive heart disease, 403-hypertensive kidney disease, 404-hypertensive heart and kidney disease), and (3) self-reported ability to read, write, speak and comprehend English.

\section{Subject Exclusion Criteria}

The exclusion criteria for the study were the following: (1) family member enrolled in the study, (2) currently participating in another study, (3) pregnancy, and (4) diagnosis of secondary hypertension (ICD-9 code 405).

\section{Instrumentation and Operationalization of Variables}

\section{Hypertension Knowledge Instrument}

The initial instrument was a 14 item multiple-choice assessment based on the seventh report of the Joint National Committee on Prevention, Detection, Evaluation and Treatment of High Blood Pressure (JNC-7), knowledge instruments from the Tennessee Pharmacists Association and the American Heart Association, and previous research (Appendix A). ${ }^{16,24,90,91}$ The items of the instrument were written to correspond with four areas of self-care behaviors identified in the literature as important to the management of hypertension. These domains were hypertension and its risk factors, diet/alcohol and 
tobacco use, blood pressure medications, and complications of hypertension. Before administering the hypertension knowledge instrument, the Flesch-Kincaid method was used to assess the reading ease and grade level of the instrument. The knowledge instrument was scored as the number of questions answered correctly.

\section{Functional Health Literacy}

The S-TOFHLA was used with permission to measure the functional health literacy of the study participants (Appendix A). The TOFHLA is a recognized and accepted measure of functional health literacy. The TOFHLA seeks to quantify functional health literacy by examining not only reading comprehension but also numeracy. ${ }^{55}$ The STOFHLA was used as a variable to not only examine the relationship between scores on the hypertension knowledge instrument and the scores on the S-TOFHLA, but also a potential confounder in determining the relationship between scores on the hypertension knowledge instrument and the presence or absence of one or more complications associated with hypertension.

Due to the time constraints associated with this study and the administration of the TOFHLA (20-30 minutes), the S-TOFHLA was administered (5-7 minutes). The passages for the S-TOFHLA are taken from instructions for the preparation for an upper gastrointestinal procedure and from the "Rights and Responsibilities" section of a Medicaid form. ${ }^{55}$ The S-TOFHLA utilizes the Cloze procedure in order to assess the functional health literacy of an individual. The Cloze procedure involves the replacement of every fifth to seventh word in a passage with a blank and multiple choices for the correct word. The individual taking the test must then decide on the appropriate word for the blank based on the grammar and context of the passage. ${ }^{55}$ The scores on the STOFHLA range from 0 to 36 with scores ranging from 0 to 16 indicating inadequate functional health literacy, 17 to 22 indicating marginal health literacy, and 23 to 36 indicating adequate health literacy. ${ }^{30}$

\section{Operationalization of Variables}

\section{Response Variables}

The response variables for the logistic regression models were the study participants' clinical outcomes, systolic blood pressure (SBP), diastolic blood pressure, (DBP), Scr, $\mathrm{HbAlc}$, and the presence or absence of complications associated with hypertension. Though an individual's blood pressure was collected as a continuous variable, blood pressure was operationalized as a two-category nominal variable, at goal or not at goal. Because health care providers seek to attain blood pressure goals as determined by the JNC-7 guidelines, this two-category operationalization of blood pressure was deemed appropriate for this study. A blood pressure less than 140/90 mm Hg was categorized as at goal for individuals who did not have type 1 or type 2 diabetes and less than 130/80 
$\mathrm{mm} \mathrm{Hg}$ for participants with type 1 or type 2 diabetes. A blood pressure greater than or equal to 140/90 $\mathrm{mm} \mathrm{Hg}$ for individuals without type 1 or type 2 diabetes or 130/80 mm $\mathrm{Hg}$ for individuals with type 1 or type 2 diabetes was categorized as not at goal.

Serum creatinine was collected as a continuous variable. However in order to use Scr in the logistic regression model, it was operationalized as a two-category nominal variable. Therefore, a Scr value greater than $1.4 \mathrm{mg} / \mathrm{dL}$ was categorized as high and a value less than or equal to $1.4 \mathrm{mg} / \mathrm{dL}$ was categorized as within normal limits.

Hemoglobin A1c was collected as a continuous variable. In order to use $\mathrm{HbAlc}$ in the logistic regression model, $\mathrm{HbAlc}$ was operationalized as a two-category nominal variable. Therefore, a HbA1c value greater than or equal to $7 \%$ was categorized as high and a value less than $7 \%$ was categorized as within normal limits.

The presence or absence of complications associated with hypertension was assessed by asking the study participants "Do you have or have you been told that you have any of the following?" Study participants were asked to check all that apply from the following options: congestive heart failure, stroke, myocardial infarction (heart attack), peripheral vascular disease, end stage renal disease, type 1diabetes, type 2 diabetes, and hyperlipidemia.

\section{Explanatory Variables}

Because individuals can be reluctant to disclose their age, study participants' ages were assessed by obtaining his/her date of birth and then subtracting this date from the date that the participant completed the questionnaire. Gender was operationalized as a twocategory nominal variable, male and female.

Race was operationalized as a five-category nominal variable, white/Caucasian, black/African American, American Indian/Alaskan native, Asian/Pacific Islander, and other. The study participant was asked to specify a race if the individual chose other as a response for the race question. Additionally, ethnicity was measured as a two-category nominal variable, Hispanic and non-Hispanic. However, because only two respondents indicated Hispanic as their ethnicity, ethnicity was not included in the logistic regression analysis for this research.

Respondents' level of educational attainment was measured as an eight-category nominal variable: less than high school, some high school, high school diploma/GED, some college, associate's degree, bachelor's degree, master's degree, or doctorate/professional degree. Level of educational attainment was collected as a measure of social facilitation in the ITHBC.

Respondents' insurance status was measured as a six-category nominal variable:

TennCare, Medicare, TennCare and Medicare, other, Medicare and other, and self-pay. 
Respondents' insurance status was collected as a measure of social facilitation in the ITHBC.

Respondents' marital status was collected as an additional measure of social facilitation. Marital status was operationalized as a two-category nominal variable: yes or no.

Duration of hypertension diagnosis was measured as a six-category ordinal variable: (1) less than one year, (2) one to five years, (3) six to ten years, (4) eleven to fifteen years, (5) sixteen to twenty years, or (6) greater than 20 years. Respondents' hypertension diagnosis duration was collected due to the potential for confounding between it and knowledge of hypertension and hypertension self-care behaviors. It was believed that the longer the duration of disease the higher the score on the hypertension knowledge instrument.

As a measure to control for the effect that previous education about hypertension could have on respondents' hypertension knowledge instrument scores, respondents were asked "Has anyone provided you with information about your high blood pressure?"

Respondents were provided with a two-category nominal response option: yes or no.

Engagement in self-care behavior management was operationalized using the following open-ended questions: "Do you monitor your salt intake?"; "How often (times per week) do you engage in physical activity?"; "What kind of physical activity do you engage in?"; and "How long do you engage in physical activity?"

The S-TOFHLA, as previously stated, was used as a measure of respondents' functional health literacy status. Scores on the S-TOFHLA were operationalized two different ways. The first involved categorizing the data into the following three-category nominal variable: scores of 0 to 16 were categorized as inadequate health literacy, scores of 17 to 22 were categorized as marginal health literacy, and scores of 23 to 36 were categorized as adequate health literacy. Although in the literature increasing functional health literacy is associated with increased disease state knowledge, inconsistencies still exist. For example, individuals with marginal or adequate functional health literacy skills possess increased disease state knowledge over those with inadequate functional health literacy skills. However, individuals with adequate functional health literacy skills do not consistently posses increased disease state knowledge compared to their counterparts with inadequate functional health literacy skills. Because of these inconsistencies, functional health literacy was operationalized by categorizing the data into the following two-category nominal variable: scores of 0 to 16 as inadequate health literacy and scores of 17 and above as marginal/adequate health literacy. ${ }^{31}$

\section{Study Procedures}

The interview flow, Figure 3.1, for this study was adapted from a previous study by Yang (Appendices A and B). ${ }^{92}$ Although, the interview flowchart indicates that the STOFHLA was administered prior to the demographic and hypertension knowledge 
Hello. My name is Crescent Rowell. I am a graduate student at the University of Tennessee. I am interested in what you know about high blood pressure.

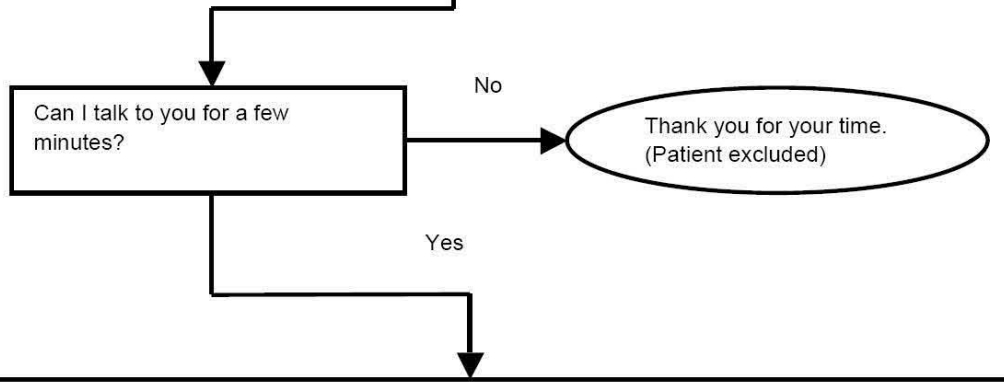

You have been invited to participate in a hypertension knowledge survey. This survey is part of a research study. If you choose to participate in this study, you will be asked to answer a series of questions about your knowledge of hypertension. The survey will require 20 to 30 minutes of your time.

By completing the survey, you will be granting your permission to use your responses in this study. All information about you and your survey responses will remain confidential.

You can stop answering the survey questions at any time. Additionally, you may refuse to answer one or all questions if you choose not to. You can ask me questions at any time. You may gain additional knowledge about managing your high blood pressure while participating in this study. There are no risks associated with this study. You will not be penalized for choosing not to participate in this study. Your participation in this study will not affect the care that you receive from your health care provider.

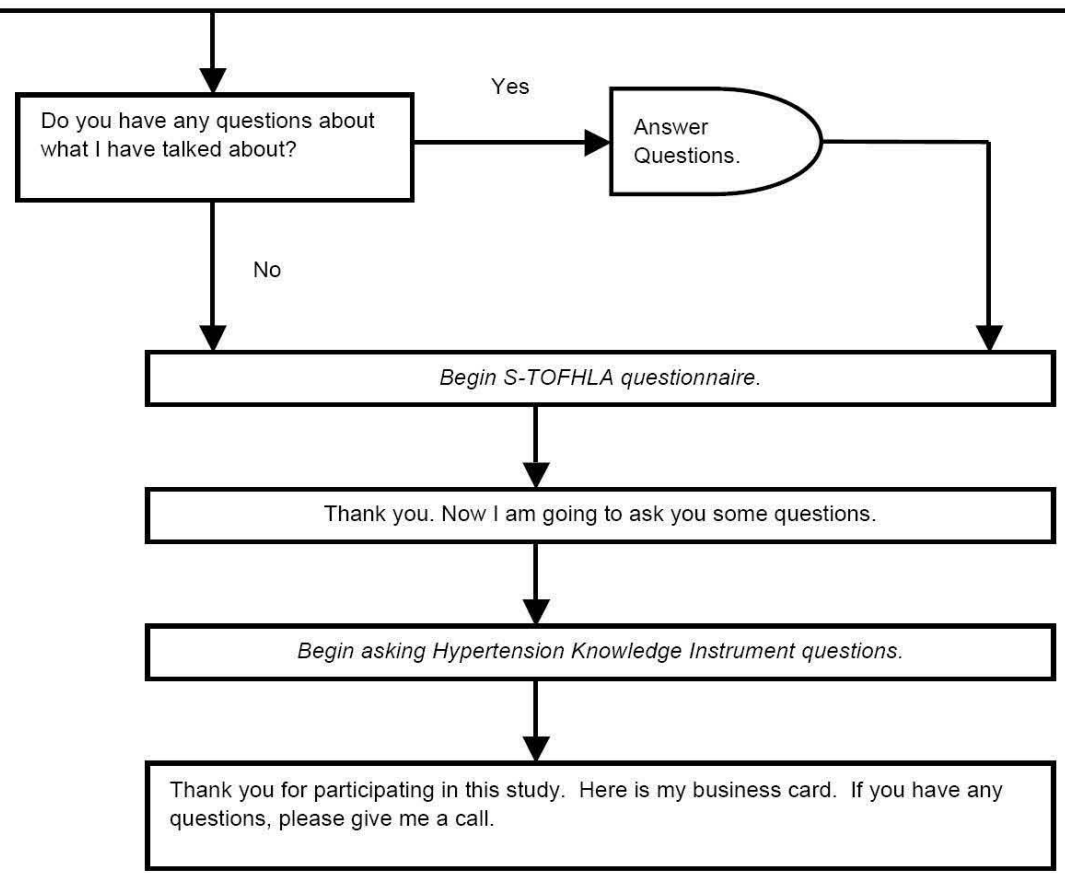

\section{Figure 3.1. Flowchart of interview procedures}

Modified with permission. Yang Y. African Americans' responses to direct-to-consumer advertising of prescription drugs [dissertation]. 2004. University of Tennessee Health Science Center, p. 69. 
instrument questions, the flow was reversed to ensure completion of the hypertension knowledge instrument. Since the hypertension knowledge instrument was the data source for the primary study objective, this reversal was deemed necessary. The investigator met with practitioners at the study site before beginning the study. Site practitioners agreed to allow the investigator to come to the site on clinic days. Individuals were identified as having hypertension by the clinic health care professional that was responsible for his/her care. The health care professional then directed the patient to the investigator. Upon meeting with the potential study participant, the investigator applied the aforementioned inclusion and exclusion criteria. If the potential participant met the inclusion criteria, the individual was asked to participate in a study investigating an individual's knowledge about hypertension or high blood pressure. Additionally, if the individual chose not to participate, the potential participant was thanked and not asked to complete the study. Individuals who agreed to participate in the study were read the demographic questionnaire and the hypertension knowledge instrument and the investigator recorded their answers. Upon completion of the demographic questionnaire and the hypertension knowledge instrument, participants were asked to self-complete the S-TOFHLA. If the individual chose not to participate, the investigator recorded the reason provided for not attempting the S-TOFHLA.

\section{Statistical Analysis}

\section{Sample Size Estimation}

Currently, there are not any agreed upon sample size estimations in the literature for factor analysis. Therefore, the investigator adhered to Pett et al's recommendation of having at least 10 subjects per item in the hypertension knowledge instrument. ${ }^{88}$ For the logistic regression analysis, the generally accepted rule of ten subjects per predictor variable was utilized. Based on this rule, a minimum sample size of 120 was needed. ${ }^{93}$

\section{Data Analysis}

\section{Descriptive Statistics}

Frequencies and means were determined for the demographic and medical history questions. For continuous variables, means and standard deviations were reported. For nominal and ordinal variables, percentages were reported. Additionally, means $(p)$ and variances (pq) were calculated for each item of the instrument. The item mean, $\mathrm{p}$, is an indicator of item difficulty and represents the proportion of people who answered the particular item correctly and ranges between zero and one for a dichotomously scored question. ${ }^{94}$ The closer an item mean is to zero the more difficult the question is assumed to be. The item variance, pq, was obtained by multiplying the proportion of people who answered an item correctly by the proportion of people who answered the item 
incorrectly. ${ }^{94}$ In addition to calculating the means and variances for each item, the mean and variance were determined for the instrument as a whole. The instrument mean was determined by summing the individual item means. The instrument variance was calculated using the following equation:

$$
\sigma^{2}=\Sigma \sigma_{i}^{2}+2 \Sigma \operatorname{cov}_{i j}
$$

where $\sigma^{2}$ is the instrument variance, $\sigma_{\mathrm{i}}^{2}$ is an item variance, and $\operatorname{cov}_{\mathrm{ij}}$ is the covariance between two items. ${ }^{94}$

\section{Kuder-Richardson 20 (KR-20)}

The Kuder-Richardson 20 (KR-20) formula is a deviation of the Cronbach's coefficient alpha that substitutes the variance of a dichotomously scored item, pq, for the variance of a continuously scored question. Like Cronbach's coefficient alpha, KR-20 is a measure of reliability that takes into account common variance. ${ }^{88}$ Even though KR-20 is generally accepted as the standard measure of internal consistency it is important to remember that the value of KR-20 increases as the length of the scale increases. In accordance with the literature, a KR-20 lower bound of 0.70 was chosen. ${ }^{27,87}$

\section{Factor Analysis}

\section{Exploratory Factor Analysis}

Exploratory factor analysis was used in this study to determine the underlying factor structure of the domain of interest, hypertension knowledge. When deciding to conduct exploratory factor analysis, there are two different methods to carry out the analysis: principal component analysis and principal axis factoring. Although both of these methods are variable reduction methods, they differ in their underlying assumptions. Principal component analysis makes no assumption regarding the underlying latent variables whereas factor analysis assumes that the latent variables are correlated. ${ }^{95}$ Principal axis factoring was the method chosen to conduct the exploratory factor analysis because it gave a cleaner solution than the principal component analysis method. Varimax rotation was chosen for the exploratory factor analysis. Varimax rotation makes high loadings higher and low loadings lower in order to maximize the difference between loadings. ${ }^{88}$ The advantages of using varimax rotation is that its solutions are clearer and more easily interpreted. Additionally, the variances do not overlap with varimax rotation. ${ }^{88}$ The disadvantage of using a varimax rotation is that it makes it difficult to determine an overall factor structure. ${ }^{88}$ The correlation matrix of the final data set was used as the input matrix. An eigenvalue greater than or equal to one along with the results of the scree plot and item loadings greater than or equal to 0.3 were was used to select the number of factors present. 


\section{Confirmatory Factor Analysis}

Confirmatory factor analysis, performed using SAS Proc Calis, was conducted in this study to investigate the factor structure identified in the exploratory factor analysis. SAS Proc Calis performs latent variable structural equation modeling (SEM). However, instead of using a SEM, a latent variable (measurement) structure was performed. The latent variable structure was used because only the structure of the loadings on the factor structure was tested. No test of the relationships between the factors or latent variables was conducted.

\section{Regression Analysis}

Regression analysis was employed in this study to understand the association between various clinical outcomes, including blood pressure, Scr, and $\mathrm{HbAlc}$, and scores on the hypertension knowledge instrument. Additionally, the relationship between the presence or absence of certain comorbid conditions and complications and scores on the hypertension knowledge instrument were also investigated using regression analysis. Potential explanatory variables or confounders for the study included age, race, scores on the S-TOFHLA, duration of hypertension, previous hypertension education, and spouse or family member with hypertension. In order to fully investigate the relationship between the clinical outcomes and scores on the hypertension knowledge instrument, a logistic regression analysis with clinical outcomes operationalized as categorical variables was conducted. Logistic regression was chosen as the method of analysis due to its use of the outcome variable as a binary variable. For this research, the outcome variable was operationalized as either at goal or not at goal or within normal limits or not. This operationalization was deemed appropriate as health care providers adhere to clinical guidelines when treating hypertensive patients and seek to treat patients to goal or within normal limits. Only predictor variables with a p-value of 0.05 or less were deemed significant.

\section{Consideration of Human Subjects}

The study was granted expedited status by the institutional review board (IRB) at the investigator's institution. Additionally, the IRB approved an alteration of participant consent. Therefore, a cover letter was used instead of the traditional informed consent form to consent patients. By participating in the study, the participants consented to not only their participation but also to the access of their medical records for the collection of study data points. Approval to conduct the study and access to medical records were granted by the clinic institutional review board. All information associated with the study and the participants were securely protected. Participants who chose not to participate in the study were not asked to complete the study questionnaires (Appendix B). 


\section{Chapter 4. Results}

\section{Study Sample Characteristics}

Two hundred subjects were recruited for the study. However, due to missing data 196 were included in the analysis. The study sample characteristics are listed in Table 4.1. The mean age of the study sample was 54 years. Seventy-four percent of the study sample was comprised of females. The self-reported race of study participants was $77 \%$ African American/black, 22\% Caucasian/white, and 1\% Asian/Pacific Islander. Over three-quarters of the study sample had a high school diploma or the equivalent or higher, with $15.3 \%$ of the study sample having earned a bachelor's or master's degree. The mean systolic blood pressure was $139.64 \mathrm{~mm} \mathrm{Hg}$ and the mean diastolic blood pressure was $82.98 \mathrm{~mm} \mathrm{Hg}$. Almost half of the study sample had had a diagnosis of hypertension for either one to five years $(27.6 \%)$ or greater than 20 years $(22.4 \%)$. Additionally, nearly $70 \%$ of the study population had received previous education about hypertension and the self-care behaviors necessary to effectively and successfully manage and treat high blood pressure. The average number of blood pressure medications being taken by study participants was 2.16 , with a range from zero medications to six medications.

\section{Instrument Scoring}

Respondent's correct answers were scored as one and incorrect answers were scored as zero. If a respondent failed to answer a knowledge question, the item was scored as zero. Additionally, if a respondent indicated multiple answers for a question, the item was scored as incorrect and thus was given a score of zero. Question 6, which asked "How many days per week should you perform moderate intensity exercise for at least 30 minutes?" was double-coded for three days or five days per week as the correct answers. Because the guidelines had just recently changed to increase the days per week of exercise from three days to five days, the acceptance of both these answers was appropriate. Additionally, question 14, which asked "How much salt should a person with high blood pressure eat each day?" was double-coded for one-half and one-fourth teaspoonful as the correct answers. The guidelines recommend that individuals consume $1500 \mathrm{mg}$ or less of sodium a day. Because one-half teaspoonful is equal to approximately $1500 \mathrm{mg}$ of sodium and one-fourth teaspoonful is equal to approximately $700 \mathrm{mg}$ of sodium, both of these answers had to be considered correct as they adhere to the guidelines of $1500 \mathrm{mg}$ or less of sodium per day. 
Table 4.1. Study sample characteristics

\begin{tabular}{|c|c|}
\hline Study Sample Characteristics $n=196$ & Value \\
\hline Age (years), mean \pm standard deviation & $54.237 \pm 14.509$ \\
\hline \multicolumn{2}{|l|}{ Sex, n $(\%)$} \\
\hline Male & $51(26)$ \\
\hline Female & $145(74)$ \\
\hline \multicolumn{2}{|l|}{ Race, $n(\%)$} \\
\hline Caucasian/White & $43(22)$ \\
\hline African American/Black & $151(77)$ \\
\hline Asian/Pacific Islander & $2(1)$ \\
\hline \multicolumn{2}{|l|}{ Ethnicity, n (\%) } \\
\hline Hispanic & $2(1)$ \\
\hline Non-Hispanic & $194(99)$ \\
\hline \multicolumn{2}{|l|}{ Education, $\mathrm{n}(\%)$} \\
\hline Less than high school & $12(6.1)$ \\
\hline Some high school & $34(17.3)$ \\
\hline High school diploma/GED & $67(34.2)$ \\
\hline Some college & $37(18.9)$ \\
\hline Associate's degree & $16(8.2)$ \\
\hline Bachelor's degree & $22(11.2)$ \\
\hline Master's degree & $8(4.1)$ \\
\hline \multicolumn{2}{|l|}{ Attempted S-TOFHLA, n (\%) } \\
\hline Yes & $74(37.8)$ \\
\hline No & $122(62.2)$ \\
\hline \multicolumn{2}{|l|}{ S-TOFHLA, n (\%) } \\
\hline Inadequate $(0-16)$ & $19(25.7)$ \\
\hline Marginal (17-22) & $4(5.4)$ \\
\hline Adequate (23-36) & $51(68.9)$ \\
\hline \multicolumn{2}{|l|}{ Insurance, $\mathrm{n}(\%)$} \\
\hline TennCare & $61(31.1)$ \\
\hline Medicare & $52(26.5)$ \\
\hline Other & $54(27.6)$ \\
\hline Self & $7(3.6)$ \\
\hline TennCare and Medicare & $18(9.2)$ \\
\hline Medicare and other & $4(2)$ \\
\hline \multicolumn{2}{|l|}{ Marital status, n (\%) } \\
\hline Married & $65(33.2)$ \\
\hline Not married & $131(66.8)$ \\
\hline
\end{tabular}


Table 4.1. (continued)

\begin{tabular}{|c|c|}
\hline Study Sample Characteristics $n=196$ & Value \\
\hline $\begin{array}{l}\text { Systolic blood pressure }(\mathrm{mm} \mathrm{Hg}), \text { mean } \pm \text { standard } \\
\text { deviation }\end{array}$ & $\begin{array}{l}139.64 \pm \\
20.414\end{array}$ \\
\hline $\begin{array}{l}\text { Diastolic blood pressure }(\mathrm{mm} \mathrm{Hg}), \text { mean } \pm \text { standard } \\
\text { deviation }\end{array}$ & $82.98 \pm 12.429$ \\
\hline $\begin{array}{l}\text { Length of disease, } \mathrm{n}(\%) \\
\text { Less than } 1 \text { year } \\
1 \text { to } 5 \text { years } \\
6 \text { to } 10 \text { years } \\
11 \text { to } 15 \text { years } \\
16 \text { to } 20 \text { years } \\
\text { greater than } 20 \text { years }\end{array}$ & $\begin{array}{l}14(7.1) \\
54(27.6) \\
47(24) \\
19(9.7) \\
18(9.2) \\
44(22.4)\end{array}$ \\
\hline $\begin{array}{l}\text { Previous blood pressure education, } \mathrm{n}(\%) \\
\text { Yes } \\
\text { No }\end{array}$ & $\begin{array}{l}136(69.4) \\
60(30.6)\end{array}$ \\
\hline $\begin{array}{l}\text { Take blood pressure medication, } \mathrm{n}(\%) \\
\text { Yes } \\
\text { No }\end{array}$ & $\begin{array}{l}193(98.5) \\
3(1.5)\end{array}$ \\
\hline $\begin{array}{l}\text { Number of blood pressure medications, mean } \pm \\
\text { standard deviation } \\
\text { Minimum } \\
\text { Maximum }\end{array}$ & $\begin{array}{l}2.16 \pm 1.046 \\
0 \\
6\end{array}$ \\
\hline $\begin{array}{l}\text { Monitor salt, } \mathrm{n}(\%) \\
\text { Yes } \\
\text { No }\end{array}$ & $\begin{array}{l}143(73) \\
53(27)\end{array}$ \\
\hline $\begin{array}{l}\text { Exercise, n }(\%) \\
\text { Yes } \\
\text { No }\end{array}$ & $\begin{array}{l}108(55.1) \\
88(44.9)\end{array}$ \\
\hline
\end{tabular}




\section{Item Analysis and Exploratory Factor Analysis}

\section{Original Hypertension Knowledge Instrument}

An item analysis was performed on the original 14 questions (Appendix C) of the hypertension knowledge instrument. The initial Cronbach's alpha was 0.597 (95\% CI: $0.505,0.672)$. Table 4.2 lists the item means, variances, and standard deviations for the original 14 questions of the hypertension knowledge instrument. Item three had the lowest mean of 0.16 , indicating it to be the most difficult of the items. Because the mean of item three was substantially lower than the other item means, item three was considered for removal from the instrument. The original hypertension knowledge instrument mean was 11.15 and the variance of the instrument was 3.617.

The inter-item correlation matrix was examined to determine which items did not correlate well with one another. Table 4.3 indicates that item 13 had poor inter-item correlation with the other items on the instrument. Out of the 14 items on the instrument, item 13 had negative inter-item correlations with five other items. Therefore, item 13 was also considered for removal from the original instrument.

The item-total statistics, as seen in Table 4.4, were calculated in order to determine how each of the items correlated with the scale as a whole. Additionally, the item-total statistics were examined to determine how to best improve the instrument's Cronbach's alpha. Based on the corrected item-total correlations, items 11 and 13 were considered for removal from the original instrument due to their low item-total correlations 0.093 and 0.033 , respectively. These low-item total correlations indicated poor correlation with the instrument as a whole.

An EFA using principal axis factoring as the extraction method and varimax rotation was conducted. The EFA resulted in a Kaiser-Meyer-Olkin (KMO) measure of sampling adequacy of 0.592 , thus indicating that factor analysis was appropriate for this set of data. Additionally, the Bartlett's test of sphericity, which tests the null hypothesis that the population correlation matrix is an identity matrix, was rejected with a p-value of 0.000 , again indicating that factor analysis is appropriate. Table 4.5 lists the communalities for each item of the instrument. The communality of an item is the total amount of variance that a factor explains. ${ }^{88}$ Communalities range from zero to one. A communality close to one indicates that the extracted factor explains nearly all of the item variance. ${ }^{88}$ By examining the resultant communalities, the variance in item three was not explained by the extracted factors, thereby giving more credence to the consideration for its removal from the instrument.

The rotated factor matrix of the original hypertension knowledge instrument, which indicates the loading of each item on the factors extracted, is shown in Table 4.6. As can be seen, the principal axis factoring method extracted 6 factors. The following four criteria were used to refine the original instrument: (1) a factor loading of 0.3 or greater, (2) maximizing the Cronbach's alpha, (3) maximizing of the item analysis results, and (4) 
Table 4.2. Item means, variances, and standard deviations for original hypertension knowledge instrument

\begin{tabular}{cccc}
\hline Item & Mean (p) & Variance (pq) & Standard Deviation \\
\hline 1 & 0.87 & 0.1131 & 0.334 \\
2 & 0.92 & 0.0736 & 0.275 \\
3 & 0.16 & 0.1344 & 0.366 \\
4 & 0.86 & 0.1204 & 0.351 \\
5 & 0.91 & 0.0819 & 0.290 \\
6 & 0.84 & 0.1344 & 0.371 \\
7 & 0.93 & 0.0651 & 0.258 \\
8 & 0.71 & 0.2059 & 0.453 \\
9 & 0.91 & 0.0819 & 0.290 \\
10 & 0.95 & 0.0475 & 0.221 \\
11 & 0.96 & 0.0384 & 0.186 \\
12 & 0.80 & 0.16 & 0.400 \\
13 & 0.76 & 0.1824 & 0.431 \\
14 & 0.58 & 0.2436 & 0.495 \\
\hline
\end{tabular}

Note: $\mathrm{P}$ indicates number of respondents who correctly answered an item; q, number of respondents who incorrectly answered an item. 
Table 4.3. Original hypertension knowledge instrument inter-item correlation matrix

\begin{tabular}{|c|c|c|c|c|c|c|c|c|c|c|c|c|c|c|}
\hline Item & 1 & 2 & 3 & 4 & 5 & 6 & 7 & 8 & 9 & 10 & 11 & 12 & 13 & 14 \\
\hline 1 & 1.00 & & & & & & & & & & & & & \\
\hline 2 & .109 & 1.00 & & & & & & & & & & & & \\
\hline 3 & .082 & .078 & 1.00 & & & & & & & & & & & \\
\hline 4 & .019 & .251 & .097 & 1.00 & & & & & & & & & & \\
\hline 5 & -.016 & .034 & .041 & .274 & 1.00 & & & & & & & & & \\
\hline 6 & .121 & .120 & .116 & .135 & .242 & 1.00 & & & & & & & & \\
\hline 7 & .013 & .351 & .012 & .170 & .186 & .038 & 1.00 & & & & & & & \\
\hline 8 & .097 & .265 & .027 & .097 & .112 & -.004 & .132 & 1.00 & & & & & & \\
\hline 9 & .143 & .163 & .041 & .274 & .205 & .051 & .049 & 034 & 1.00 & & & & & \\
\hline 10 & .259 & .354 & .037 & .170 & .087 & .274 & .026 & .059 & .167 & 1.00 & & & & \\
\hline 11 & -.074 & .043 & .083 & .000 & .034 & -.011 & .053 & .061 & .034 & .205 & 1.00 & & & \\
\hline 12 & .154 & .271 & .181 & .162 & .019 & .056 & .110 & .194 & .196 & .117 & -.027 & 1.00 & & \\
\hline 13 & .067 & .047 & .149 & -.029 & -.140 & -.091 & -.020 & .008 & -.099 & .030 & .146 & .162 & 1.00 & \\
\hline 14 & .079 & .125 & .056 & .038 & .088 & .073 & .086 & .425 & .017 & .038 & .004 & .018 & -.026 & 1.00 \\
\hline
\end{tabular}


Table 4.4. Original hypertension knowledge instrument item-total statistics

\begin{tabular}{ccccc}
\hline Item & $\begin{array}{c}\text { Scale Mean if } \\
\text { Item Deleted }\end{array}$ & $\begin{array}{c}\text { Scale Variance } \\
\text { if Item Deleted }\end{array}$ & $\begin{array}{c}\text { Corrected } \\
\text { Item-Total } \\
\text { Correlation }\end{array}$ & $\begin{array}{c}\text { Cronbach's } \\
\text { Alpha if Item } \\
\text { Deleted }\end{array}$ \\
\hline 1 & 10.28 & 3.259 & 0.204 & 0.557 \\
2 & 10.23 & 3.134 & 0.419 & 0.524 \\
3 & 10.99 & 3.226 & 0.196 & 0.559 \\
4 & 10.30 & 3.132 & 0.291 & 0.540 \\
5 & 10.24 & 3.314 & 0.208 & 0.557 \\
6 & 10.32 & 3.233 & 0.186 & 0.561 \\
7 & 10.22 & 3.344 & 0.219 & 0.556 \\
8 & 10.44 & 2.924 & 0.315 & 0.531 \\
9 & 10.24 & 3.304 & 0.218 & 0.555 \\
10 & 10.20 & 3.312 & 0.320 & 0.545 \\
11 & 10.19 & 3.518 & 0.093 & 0.572 \\
12 & 10.35 & 3.019 & 0.315 & 0.533 \\
13 & 10.40 & 3.379 & 0.033 & 0.600 \\
14 & 10.57 & 3.005 & 0.214 & 0.561 \\
\hline
\end{tabular}


Table 4.5. Original hypertension knowledge instrument EFA communalities

\begin{tabular}{ccc}
\hline Item & Initial & Extraction \\
\hline 1 & 0.131 & 0.201 \\
2 & 0.339 & 0.725 \\
3 & 0.080 & 0.138 \\
4 & 0.187 & 0.275 \\
5 & 0.194 & 0.511 \\
6 & 0.158 & 0.160 \\
7 & 0.179 & 0.231 \\
8 & 0.267 & 0.537 \\
9 & 0.163 & 0.188 \\
10 & 0.289 & 0.962 \\
11 & 0.110 & 0.268 \\
12 & 0.182 & 0.365 \\
13 & 0.109 & 0.285 \\
14 & 0.198 & 0.364 \\
\hline
\end{tabular}


Table 4.6. EFA rotated factor matrix of original hypertension knowledge instrument

\begin{tabular}{ccccccc}
\hline Item & \multicolumn{6}{c}{ Factor } \\
\cline { 2 - 7 } & $\mathbf{1}$ & $\mathbf{2}$ & $\mathbf{3}$ & $\mathbf{4}$ & $\mathbf{5}$ & $\mathbf{6}$ \\
\hline 1 & .336 & & & .104 & .215 & 0.173 \\
2 & .250 & & .790 & .139 & .134 & \\
3 & & & & & .345 & \\
4 & & .431 & .258 & & .138 & \\
5 & & .693 & & .114 & & \\
6 & .253 & .308 & & & & \\
7 & & .177 & .423 & & & \\
8 & & & .192 & .696 & .115 & \\
9 & .142 & .342 & .128 & & .147 & -.111 \\
10 & .913 & .147 & .158 & & & .284 \\
11 & & & & & & .507 \\
12 & .104 & & .222 & & .521 & -.141 \\
13 & & -.221 & & & .419 & .243 \\
14 & & & & .598 & & \\
\hline
\end{tabular}


theoretical soundness of the factor structure. Based on the aforementioned criteria nine items were retained from the original 14 items that comprised the hypertension knowledge instrument. On the first round of EFA item three was removed due to a substantially low item mean compared to the other items on the instrument. Additionally, item 13 was also removed from the instrument due to its low item-total correlation and its negative inter-item correlation with 5 out of the 14 items.

Once items 3 and 13 were removed from the instrument the EFA was run again on the remaining 12 items. Although, the Cronbach's alpha increased from 0.597 to 0.611 , items 6 and 11 did not load on any of the factors that were extracted from the subsequent EFA. Additionally, item 11 still had a low item-total correlation of 0.047 . Based on this result, another EFA was run with items 3, 6, 11 and 13 removed. This combination of 10 items on the hypertension knowledge instrument resulted in a further increase in the Cronbach's alpha to 0.616. Since the ten item EFA's scree plot (Figure 4.1) indicated three factors present, an EFA was then run forcing the extraction of three factors. This EFA resulted in all of the ten remaining items except for item seven loading on one of the three factors. Since item seven did not meet the rule of a factor loading of 0.3 or higher, it was also removed from the instrument.

\section{Final Hypertension Knowledge Instrument}

The final hypertension knowledge instrument consisted of the following nine items: items $1,2,4,5,8,9,10,12$, and 14. The Cronbach's alpha for the refined instrument was 0.598 (95\% CI: 0.504, 0.674). The item means, variance and standard deviation are listed in Table 4.7. The item means ranged from 0.58 to 0.95 . The refined instrument mean was $7.51 \pm 1.524$, and the instrument variance was determined to be 2.323 .

The inter-item correlation for the final hypertension knowledge instrument is shown in Table 4.8. This correlation matrix was used as the input correlation matrix for the CFA. Table 4.9 shows the item-total statistics for the final knowledge instrument. As can be seen, removal of any one of the items would not result in a higher Cronbach's alpha.

An EFA was conducted on the final knowledge instrument in order to determine the factor structure of the nine items. The KMO measure of sampling adequacy was 0.628 indicating that factor analysis was appropriate. Additionally, the Bartlett's test of sphericity rejected the null hypothesis that the population correlation matrix was an identity matrix with a $p$-value of $<0.001$. The communalities of the final instrument are shown in Table 4.10 and the final factor loadings are showing in Table 4.11. Factor 1 was comprised of item 8 and 14, both of which measure diet and more specifically salt intake knowledge. Items 1, 2, 10, and 12 loaded onto factor 2 and measure general hypertension knowledge. Finally, items four, five, and nine all measure risk factors and complications of hypertension and comprise factor three. 


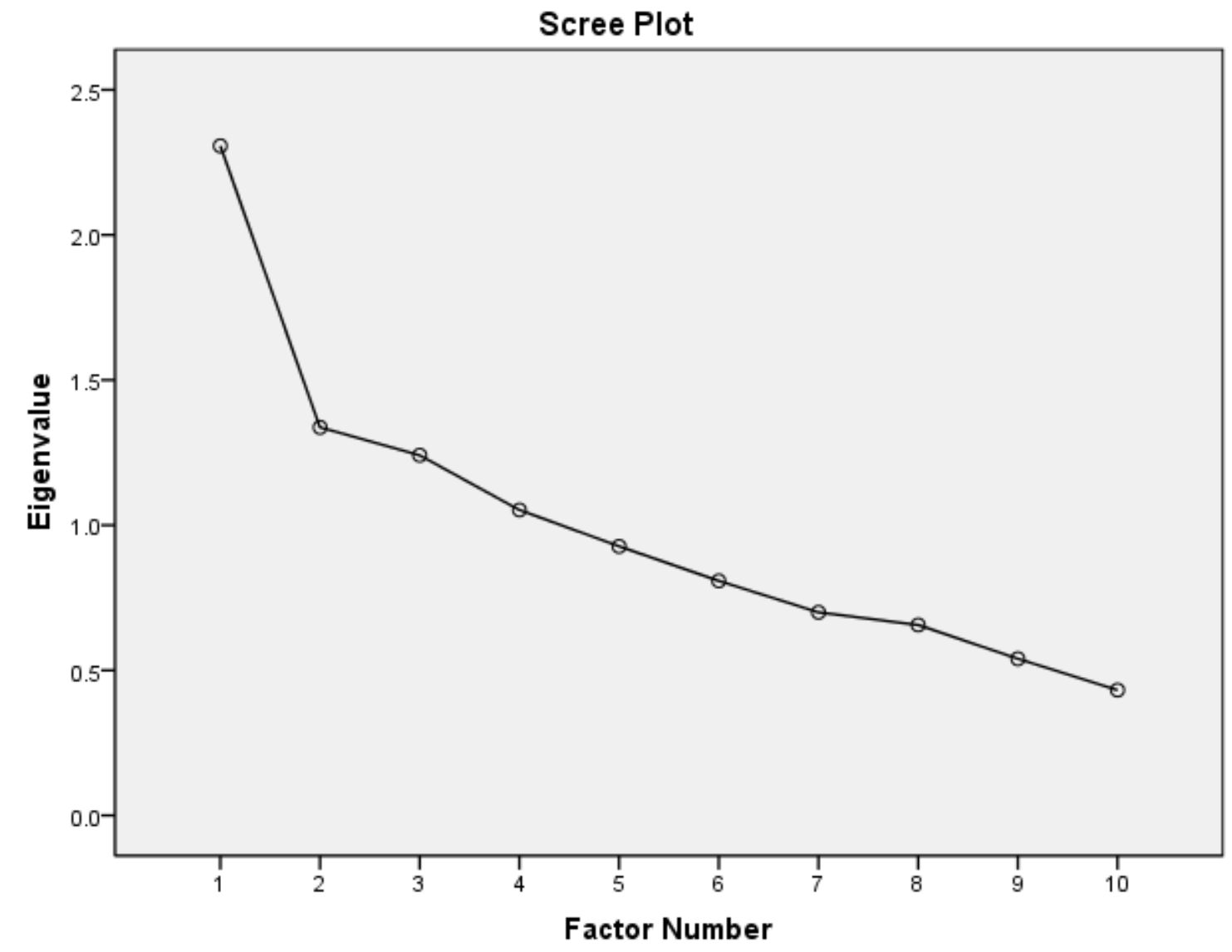

Figure 4.1. Exploratory factor analysis scree plot indicating three factor structure 
Table 4.7. Item means, variances, and standard deviations for the refined hypertension knowledge instrument

\begin{tabular}{cccc}
\hline Item & Mean (p) & Variance (pq) & Standard Deviation \\
\hline 1 & 0.87 & 0.1131 & 0.334 \\
2 & 0.92 & 0.0736 & 0.275 \\
4 & 0.86 & 0.1204 & 0.351 \\
5 & 0.91 & 0.0819 & 0.290 \\
8 & 0.71 & 0.2059 & 0.453 \\
9 & 0.91 & 0.0819 & 0.290 \\
10 & 0.95 & 0.0475 & 0.221 \\
12 & 0.80 & 0.16 & 0.400 \\
14 & 0.58 & 0.2436 & 0.495 \\
\hline
\end{tabular}

Note: P indicates number of respondents who correctly answered an item; q, number of respondents who incorrectly answered an item. 
Table 4.8. Inter-item correlation matrix for final hypertension knowledge instrument

\begin{tabular}{cccccccccc}
\hline Item & $\mathbf{1}$ & $\mathbf{2}$ & $\mathbf{4}$ & $\mathbf{5}$ & $\mathbf{8}$ & $\mathbf{9}$ & $\mathbf{1 0}$ & $\mathbf{1 2}$ & $\mathbf{1 4}$ \\
\hline 1 & 1.00 & & & & & & & & \\
2 & .109 & 1.00 & & & & & & & \\
4 & .019 & .251 & 1.00 & & & & & & \\
5 & -.016 & .034 & .274 & 1.00 & & & & & \\
8 & .097 & .265 & .097 & .112 & 1.00 & & & & \\
9 & .143 & .163 & .274 & .205 & 034 & 1.00 & & & \\
10 & .259 & .354 & .170 & .087 & .059 & .167 & 1.00 & & \\
12 & .154 & .271 & .162 & .019 & .194 & .196 & .117 & 1.00 & \\
14 & .079 & .125 & .038 & .088 & .425 & .017 & .038 & .018 & 1.00 \\
\hline
\end{tabular}


Table 4.9. Final hypertension knowledge instrument item-total statistics

\begin{tabular}{ccccc}
\hline Item & $\begin{array}{c}\text { Scale Mean if } \\
\text { Item Deleted }\end{array}$ & $\begin{array}{c}\text { Scale Variance } \\
\text { if Item Deleted }\end{array}$ & $\begin{array}{c}\text { Corrected } \\
\text { Item-Total } \\
\text { Correlation }\end{array}$ & $\begin{array}{c}\text { Cronbach's } \\
\text { Alpha if Item } \\
\text { Deleted }\end{array}$ \\
\hline 1 & 6.64 & 2.027 & 0.193 & 0.565 \\
2 & 6.59 & 1.945 & 0.395 & 0.519 \\
4 & 6.65 & 1.920 & 0.288 & 0.540 \\
5 & 6.60 & 2.077 & 0.195 & 0.564 \\
8 & 6.80 & 1.681 & 0.372 & 0.510 \\
9 & 6.60 & 2.015 & 0.272 & 0.546 \\
10 & 6.56 & 2.094 & 0.283 & 0.549 \\
12 & 6.71 & 1.869 & 0.269 & 0.546 \\
14 & 6.93 & 1.769 & 0.235 & 0.567 \\
\hline
\end{tabular}


Table 4.10. Final hypertension knowledge instrument EFA communalities

\begin{tabular}{ccc}
\hline Item & Initial & Extraction \\
\hline 1 & 0.103 & 0.133 \\
2 & 0.250 & 0.365 \\
4 & 0.177 & 0.368 \\
5 & 0.115 & 0.265 \\
8 & 0.254 & 0.754 \\
9 & 0.142 & 0.233 \\
10 & 0.192 & 0.312 \\
12 & 0.135 & 0.155 \\
14 & 0.190 & 0.238 \\
\hline
\end{tabular}


Table 4.11. EFA rotated factor matrix of final hypertension knowledge instrument

\begin{tabular}{cccc}
\hline Item & \multicolumn{3}{c}{ Factor } \\
\cline { 2 - 4 } & $\mathbf{1}$ & $\mathbf{2}$ & $\mathbf{3}$ \\
\hline 1 & & $\mathbf{0 . 3 6 2}$ & \\
2 & 0.188 & $\mathbf{0 . 5 5 1}$ & 0.160 \\
4 & & 0.205 & $\mathbf{0 . 5 7 0}$ \\
5 & 0.100 & & $\mathbf{0 . 5 0 3}$ \\
8 & $\mathbf{0 . 8 5 0}$ & 0.167 & \\
9 & & 0.262 & $\mathbf{0 . 4 0 4}$ \\
10 & & $\mathbf{0 . 5 4 3}$ & 0.129 \\
12 & 0.114 & $\mathbf{0 . 3 5 3}$ & 0.131 \\
14 & $\mathbf{0 . 4 8 3}$ & & \\
\hline
\end{tabular}

Note: Bold type indicates the factor on which the item loaded. 


\section{Confirmatory Factor Analysis}

A CFA was conducted in order to verify the factor structure identified from the EFA. For the CFA manifest errors were assumed to be orthogonal and the following items were forced to load on the respective factors: item eight and factor one, item two and factor two, and item four and factor three. Table 4.12 shows the results of various fit indices. These fit indices indicated that the factor structure identified in the EFA and specified in the CFA was a good fit for the data. The chi-square statistic tests the null hypothesis that the implied covariance matrix is equal to the observed covariance matrix. Because the CFA in this study resulted in a nonsignificant chi-square statistic, the investigator failed to reject the null hypothesis, thus indicating that the specified model did indeed fit the data. However, because the chi-square statistic is sensitive to sample size, additional fit indices were also examined to determine the fit of the model. The GFI and the AGFI are indices whose values range from zero to one. The closer to one the better the model fit. It is generally accepted that a GFI greater than or equal to 0.96, as obtained in this study, is an ideal fit of the model. The RMR operates in the opposite manner than the GFI, with a RMR of less than 0.05 indicating good model fit. Therefore, this study's RMR of 0.0052 indicated good model fit. Finally, as can be seen in Table 4.13 , factors one and two and factors two and three were significantly correlated with one another. Additionally, factors one and three were not significantly correlated with one another.

\section{Logistic Regression}

Logistic regression was conducted to examine the relationship between adequate hypertension knowledge, defined as a score of $70 \%$ or higher on the hypertension knowledge instrument, and health outcomes such as SBP and DBP control, overall blood pressure control, Scr control and HbA1c control. In order to adequately characterize the ITHBC, the theoretical framework of the study, eight variables were included in the logistic regression model. The variable adequate hypertension knowledge was included in the regression model to represent knowledge and beliefs. The variables marital status, level of educational attainment, and insurance status were included to represent the social facilitation aspect of the ITHBC. The proxies for engagement in self-care behaviors were the variables whether the respondent monitors their salt intake, whether the respondent exercises, the number of blood pressure medications, and the number of hypertensionrelated complications. In order to comply with what has been shown in the literature the four variables, age, race, sex, and education were included in all of the models as confounders. All of the aforementioned variables were included in the logistic regression model whether or not statistical significance was achieved. Statistical significance was set at a p-value of 0.05 or less.

Ethnicity was not included in the models because only two study participants indicated their ethnicity as Hispanic. Additionally, the dummy variable for Asian/Pacific Islander was not included in the logistic regression models due to only two respondents reporting Asian/Pacific Islander as their race, and thus resulting in exceptionally large standard 
Table 4.12. Confirmatory factor analysis fit indices

\begin{tabular}{lc}
\hline \multicolumn{1}{c}{ Fit Index } & Value \\
\hline Fit function & 0.1573 \\
Goodness of Fit Index (GFI) & 0.9861 \\
GFI Adjusted for degrees of freedom (AGFI) & 0.9425 \\
Root Mean Square Residual (RMR) & 0.0052 \\
Standardized Root Mean Square Residual (SRMR) & 0.0485 \\
Chi square, degrees of freedom, p-value & $30.6741,25,0.2$ \\
\hline
\end{tabular}

Table 4.13. Covariances among factors

\begin{tabular}{cccccc}
\hline Variable 1 & Variable 2 & Parameter & Estimate & $\begin{array}{c}\text { Standard } \\
\text { Error }\end{array}$ & t-Value \\
\hline Factor 1 & Factor 2 & phi12 & 0.02904 & 0.00846 & 3.43 \\
Factor 1 & Factor 3 & phi13 & 0.01551 & 0.01016 & 1.53 \\
Factor 2 & Factor 3 & phi23 & 0.02180 & 0.00628 & 3.47 \\
\hline
\end{tabular}


errors. Finally, the S-TOFHLA was not included in the regression models because only 74 out of the 200 study participants completed the S-TOFHLA. Additionally, there appeared to be selection bias associated with completing the S-TOFHLA as the scores were skewed to the left. The mean S-TOFHLA score for the 74 participants who completed the S-TOFHLA was 25.34 with a range of 0 to 36.

Table 4.14 shows the final regression model for systolic blood pressure control as the dependent variable. No significant relationship between hypertension knowledge and SBP control was determined. Two variables, length of disease and number of comorbid disease states, were found to have a significant relationship with systolic blood pressure control. Compared to respondents who had been diagnosed with hypertension for less than one year, respondents who had been diagnosed with high blood pressure for 6 to 10 years were 5.8 times more likely to exhibit systolic blood pressure control, after controlling for all other variables in the model. Additionally for every one unit increase in the number of comorbid diseases a respondent had, they were approximately $43 \%$ less likely to achieve systolic blood pressure control.

Table 4.15 shows the results for the final regression model with diastolic blood pressure control as the dependent variable. As in the SBP control model, hypertension knowledge was not significantly associated with DBP control. The variables number of comorbid disease states and age achieved statistical significance in the model. For every one unit increase in the number of comorbid diseases a participant had, they were approximately $47 \%$ less likely to achieve diastolic blood pressure control, after controlling for all other variables in the model. For every one unit increase in a participant's age, they were 7\% more likely to achieve diastolic blood pressure control, after controlling for all other variables in the model.

The results of the logistic regression model with total blood pressure control as the dependent variable are shown in Table 4.16. Adequate hypertension knowledge was not significantly associated with total blood pressure control. The number of comorbid diseases was the only predictor variable that exhibited significance in the regression model for total blood pressure control. Every one unit increase in the number of comorbid diseases a participant had was associated with being approximately $44 \%$ less likely to achieve total blood pressure control, after controlling for all other variables in the model. The variable age approached significance as evident by a p-value of 0.051 .

A logistic regression analysis was conducted with Scr within normal limits as the dependent variable. Table 4.17 shows the results of this logistic regression analysis. Adequate hypertension knowledge was not significantly associated with having a Scr within normal limits. The variables number of blood pressure medication and number of comorbid disease states were significantly associated with having a Scr within normal limits. After controlling for all other variables in the logistic regression model, every one unit increase in the number of blood pressure medications was associated with being 55\% less likely to have a Scr within normal limits. Every one unit increase in the number of comorbid disease states a participant had was associated with being $61 \%$ less likely to have a Scr within normal limits, after controlling for all other variables in the model. 
Table 4.14. Final regression model for systolic blood pressure control

\begin{tabular}{|c|c|c|c|c|c|c|c|c|}
\hline \multirow[t]{2}{*}{ Variable } & \multirow[t]{2}{*}{ B } & \multirow[t]{2}{*}{ S.E. } & \multirow[t]{2}{*}{ Wald } & \multirow[t]{2}{*}{ df } & \multirow[t]{2}{*}{ Sig. } & \multirow[t]{2}{*}{$\begin{array}{l}\text { Odds } \\
\text { Ratio }\end{array}$} & \multicolumn{2}{|c|}{$\begin{array}{l}\text { 95\% CI for } \\
\text { Odds Ratio }\end{array}$} \\
\hline & & & & & & & Lower & Upper \\
\hline Constant & -0.815 & 1.901 & 0.184 & 1 & 0.668 & 0.443 & & \\
\hline $\begin{array}{l}\text { Adequate } \\
\text { HTN } \\
\text { knowledge }(\geq \\
70 \% \text { correct })\end{array}$ & -0.317 & 0.458 & 0.481 & 1 & 0.488 & 0.728 & 0.297 & 1.786 \\
\hline $\begin{array}{l}\text { LOD } \\
\qquad \begin{array}{l}\text { LOD }<1 \\
\text { year } \\
\text { (reference) }\end{array}\end{array}$ & & & & & & & & \\
\hline $\begin{array}{l}\text { LOD 1-5 } \\
\text { years }\end{array}$ & 1.230 & 0.699 & 3.101 & 1 & 0.078 & 3.422 & 0.870 & 13.458 \\
\hline $\begin{array}{l}\text { LOD 6-10 } \\
\text { years }\end{array}$ & 1.764 & 0.730 & 5.835 & 1 & 0.016 & 5.837 & 1.395 & 24.430 \\
\hline $\begin{array}{l}\text { LOD } 11- \\
15 \text { years }\end{array}$ & 1.248 & 0.852 & 2.143 & 1 & 0.143 & 3.483 & 0.655 & 18.510 \\
\hline $\begin{array}{l}\text { LOD 16- } \\
20 \text { years }\end{array}$ & 0.427 & 0.948 & 0.203 & 1 & 0.653 & 1.532 & 0.239 & 9.833 \\
\hline $\begin{array}{l}\mathrm{LOD} \geq 20 \\
\text { years }\end{array}$ & 0.446 & 0.808 & 0.304 & 1 & 0.581 & 1.562 & 0.320 & 7.616 \\
\hline Married & 0.105 & 0.374 & 0.080 & 1 & 0.778 & 1.111 & 0.534 & 2.311 \\
\hline Monitors salt & -0.287 & 0.394 & 0.530 & 1 & 0.466 & 0.751 & 0.347 & 1.624 \\
\hline Exercises & 0.353 & 0.337 & 1.097 & 1 & 0.295 & 1.424 & 0.735 & 2.757 \\
\hline $\begin{array}{l}\text { Number of BP } \\
\text { meds }\end{array}$ & -0.238 & 0.187 & 1.634 & 1 & 0.201 & 0.788 & 0.547 & 1.136 \\
\hline $\begin{array}{l}\text { Number of } \\
\text { diseases }\end{array}$ & -0.566 & 0.198 & 8.178 & 1 & 0.004 & 0.568 & 0.385 & 0.837 \\
\hline $\begin{array}{l}\text { Age } \\
\text { Sex }\end{array}$ & 0.005 & 0.017 & 0.091 & 1 & 0.763 & 1.005 & 0.972 & 1.040 \\
\hline $\begin{array}{l}\text { Female } \\
\text { (reference) }\end{array}$ & & & & & & & & \\
\hline Male & -0.64 & 0.405 & 0.025 & 1 & 0.874 & 0.938 & 0.424 & 2.075 \\
\hline $\begin{array}{l}\text { Race } \\
\quad \text { Caucasian } \\
\text { (reference) }\end{array}$ & & & & & & & & \\
\hline $\begin{array}{l}\text { African } \\
\text { American }\end{array}$ & 0.002 & 0.407 & 0.000 & 1 & 0.995 & 1.002 & 0.452 & 2.225 \\
\hline
\end{tabular}


Table 4.14. (continued)

\begin{tabular}{|c|c|c|c|c|c|c|c|c|}
\hline \multirow[t]{2}{*}{ Variable } & \multirow[t]{2}{*}{ B } & \multirow[t]{2}{*}{ S.E. } & \multirow[t]{2}{*}{ Wald } & \multirow[t]{2}{*}{ df } & \multirow[t]{2}{*}{ Sig. } & \multirow[t]{2}{*}{$\begin{array}{l}\text { Odds } \\
\text { Ratio }\end{array}$} & \multicolumn{2}{|c|}{$\begin{array}{l}\text { 95\% CI for } \\
\text { Odds Ratio }\end{array}$} \\
\hline & & & & & & & Lower & Upper \\
\hline \multicolumn{9}{|l|}{ Education } \\
\hline \multirow{2}{*}{\multicolumn{9}{|c|}{$\begin{array}{l}\text { Less than } \\
\text { HS diploma } \\
\text { (reference) }\end{array}$}} \\
\hline & & & & & & & & \\
\hline $\begin{array}{l}\text { HS diploma } \\
\text { or GED }\end{array}$ & -0.155 & 0.485 & 0.102 & 1 & 0.750 & 0.857 & 0.331 & 2.218 \\
\hline $\begin{array}{l}\text { Greater } \\
\text { than HS } \\
\text { diploma }\end{array}$ & 0.113 & 0.503 & 0.050 & 1 & 0.822 & 1.120 & 0.418 & 3.001 \\
\hline \multicolumn{9}{|l|}{ Insurance } \\
\hline \multicolumn{9}{|l|}{ Medicare/ } \\
\hline \multicolumn{9}{|l|}{$\begin{array}{l}\text { Other } \\
\text { (reference) }\end{array}$} \\
\hline TennCare & 0.774 & 1,462 & 0.280 & 1 & 0.597 & 2.168 & 0.124 & 38.036 \\
\hline Medicare & 1.247 & 1.416 & 0.775 & 1 & 0.379 & 3.479 & 0.217 & 55.851 \\
\hline Private & 0.194 & 1.407 & 0.019 & 1 & 0.890 & 1.214 & 0.077 & 19.118 \\
\hline Self-pay & -0.961 & 1.794 & 0.287 & 1 & 0.592 & 0.383 & 0.011 & 12.886 \\
\hline $\begin{array}{l}\text { TennCare/ } \\
\text { Medicare }\end{array}$ & 0.671 & 1.487 & 0.204 & 1 & 0.652 & 1.956 & 0.106 & 36.107 \\
\hline
\end{tabular}

$\mathrm{n}=196$

Notes: B indicates logistic regression coefficient; S.E., standard error; Wald, Wald chisquare statistic; df, degrees of freedom; Sig., significance; HTN, hypertension; LOD, length of hypertensive disease; BP meds, blood pressure medications; HS, high school; GED, general education diploma. 
Table 4.15. Final regression model for diastolic blood pressure control

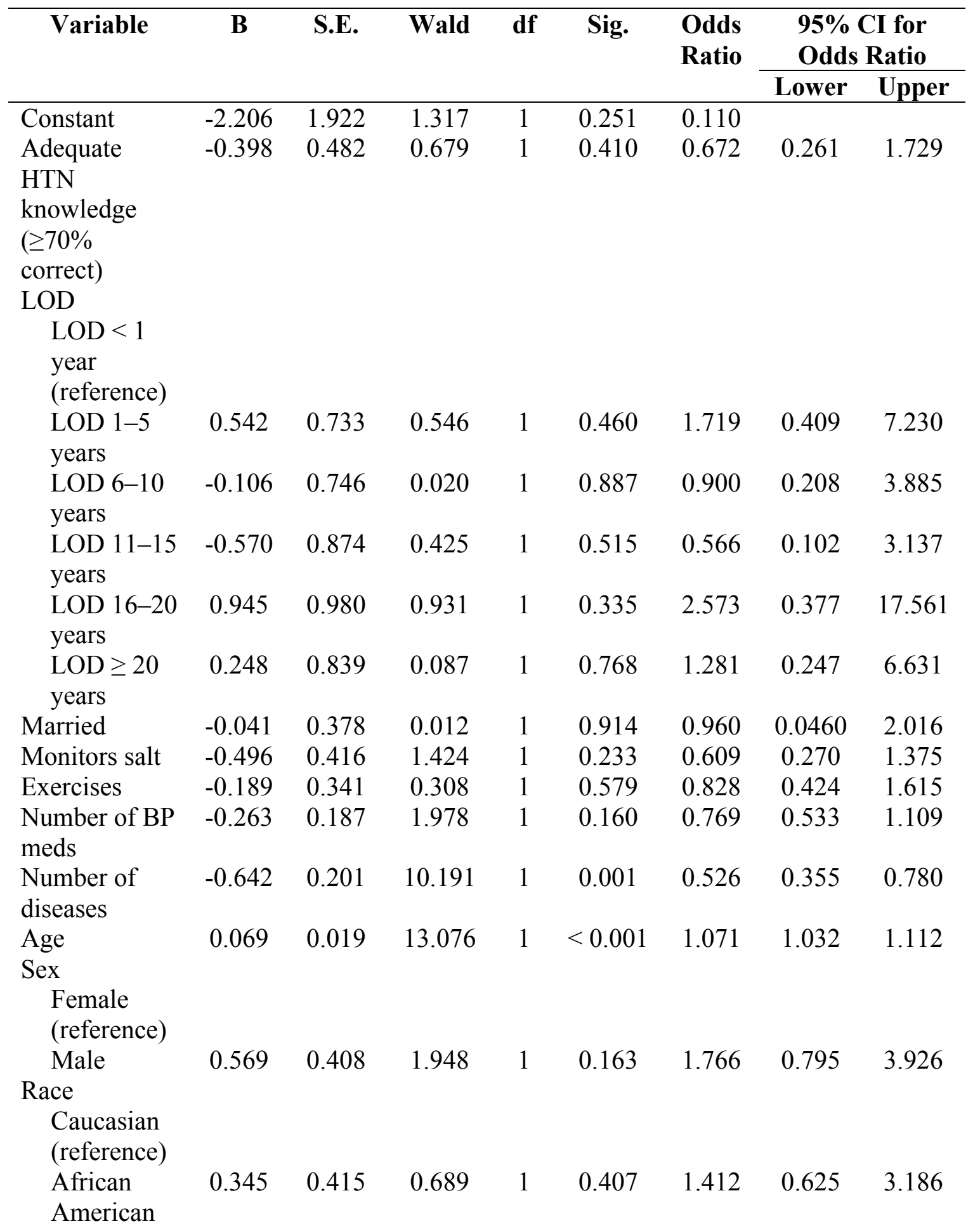


Table 4.15. (continued)

\begin{tabular}{|c|c|c|c|c|c|c|c|c|}
\hline \multirow[t]{2}{*}{ Variable } & \multirow[t]{2}{*}{ B } & \multirow[t]{2}{*}{ S.E. } & \multirow[t]{2}{*}{ Wald } & \multirow[t]{2}{*}{ df } & \multirow[t]{2}{*}{ Sig. } & \multirow[t]{2}{*}{$\begin{array}{l}\text { Odds } \\
\text { Ratio }\end{array}$} & \multicolumn{2}{|c|}{$\begin{array}{l}\text { 95\% CI for } \\
\text { Odds Ratio }\end{array}$} \\
\hline & & & & & & & Lower & Upper \\
\hline \multicolumn{9}{|l|}{ Education } \\
\hline \multirow{2}{*}{\multicolumn{9}{|c|}{$\begin{array}{l}\text { Less than } \\
\text { HS diploma } \\
\text { (reference) }\end{array}$}} \\
\hline & & & & & & & & \\
\hline $\begin{array}{l}\text { HS diploma } \\
\text { or GED }\end{array}$ & -0.045 & 0.496 & 0.008 & 1 & 0.928 & 0.956 & 0.361 & 2.529 \\
\hline $\begin{array}{l}\text { Greater } \\
\text { than HS } \\
\text { diploma }\end{array}$ & 0.480 & 0.523 & 0.842 & 1 & 0.359 & 1.615 & 0.580 & 4.501 \\
\hline \multicolumn{9}{|l|}{ Insurance } \\
\hline \multicolumn{9}{|l|}{ Medicare/ } \\
\hline \multicolumn{9}{|l|}{$\begin{array}{l}\text { Other } \\
\text { (reference) }\end{array}$} \\
\hline TennCare & 0.331 & 1.389 & 0.057 & 1 & 0.812 & 1.393 & 0.091 & 21.202 \\
\hline Medicare & 0.051 & 1.342 & 0.001 & 1 & 0.970 & 1.052 & 0.076 & 14.592 \\
\hline Private & -0.019 & 1.327 & 0.000 & 1 & 0.989 & 0.981 & 0.073 & 13.232 \\
\hline Self-pay & 0.325 & 1.533 & 0.045 & 1 & 0.832 & 1.384 & 0.069 & 27.941 \\
\hline $\begin{array}{l}\text { TennCare/ } \\
\text { Medicare }\end{array}$ & -0.757 & 1.417 & 0.285 & 1 & 0.593 & 0.469 & 0.029 & 7.543 \\
\hline
\end{tabular}

$\mathrm{n}=196$

Notes: B indicates logistic regression coefficient; S.E., standard error; Wald, Wald chisquare statistic; df, degrees of freedom; Sig., significance; HTN, hypertension; LOD, length of hypertensive disease; BP meds, blood pressure medications; HS, high school; GED, general education diploma. 
Table 4.16. Final regression model for total blood pressure control

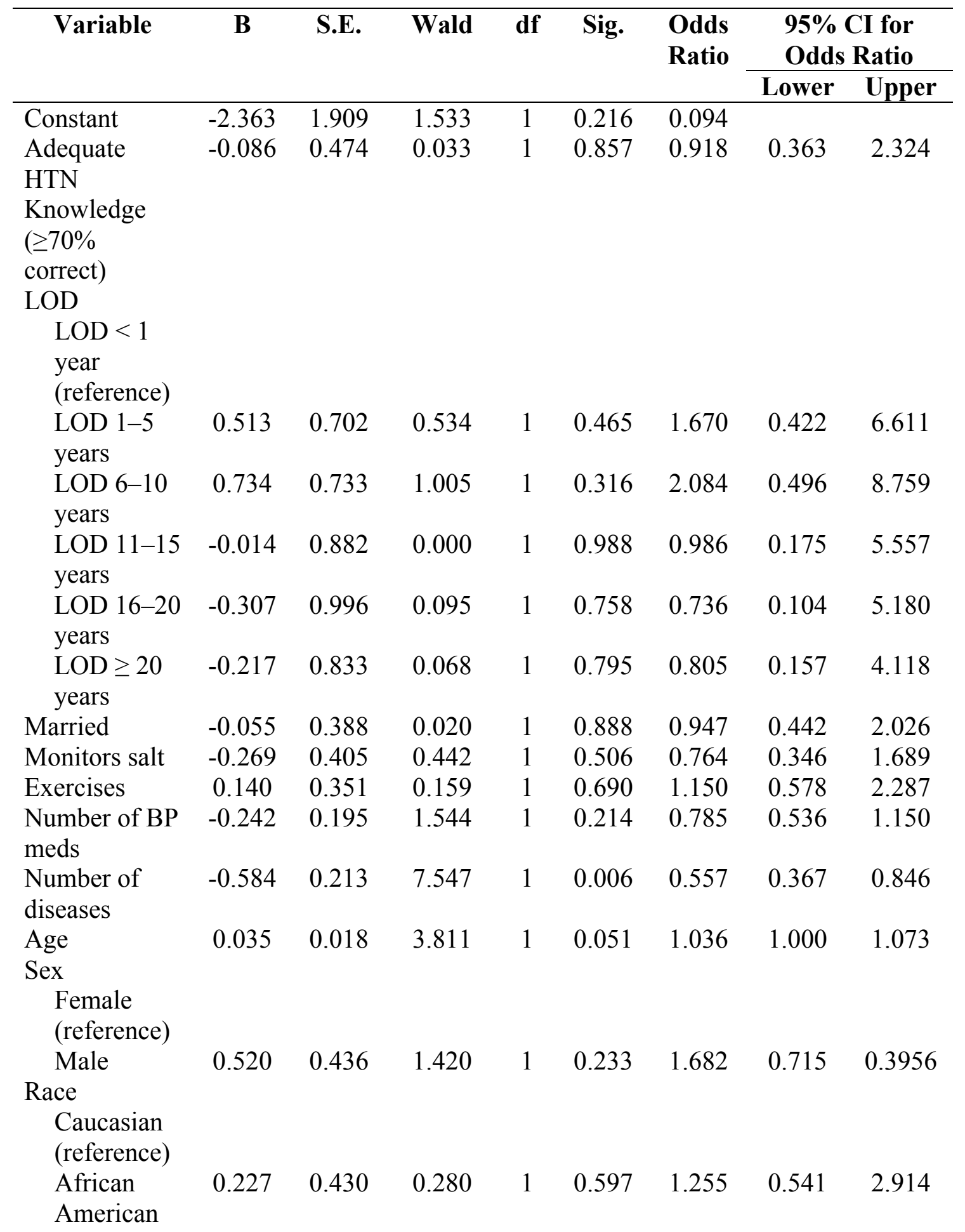


Table 4.16. (continued)

\begin{tabular}{|c|c|c|c|c|c|c|c|c|}
\hline \multirow[t]{2}{*}{ Variable } & \multirow[t]{2}{*}{ B } & \multirow[t]{2}{*}{ S.E. } & \multirow[t]{2}{*}{ Wald } & \multirow[t]{2}{*}{ df } & \multirow[t]{2}{*}{ Sig. } & \multirow[t]{2}{*}{$\begin{array}{l}\text { Odds } \\
\text { Ratio }\end{array}$} & \multicolumn{2}{|c|}{$\begin{array}{l}\text { 95\% CI for } \\
\text { Odds Ratio }\end{array}$} \\
\hline & & & & & & & Lower & Upper \\
\hline \multicolumn{9}{|l|}{ Education } \\
\hline \multicolumn{9}{|l|}{ Less than } \\
\hline \multicolumn{9}{|l|}{$\begin{array}{l}\text { HS diploma } \\
\text { (reference) }\end{array}$} \\
\hline $\begin{array}{l}\text { HS diploma } \\
\text { or GED }\end{array}$ & -0.252 & 0.506 & 0.248 & 1 & 0.618 & 0.777 & 0.288 & 2.095 \\
\hline $\begin{array}{l}\text { Greater } \\
\text { than HS } \\
\text { diploma }\end{array}$ & 0.171 & 0.522 & 0.107 & 1 & 0.743 & 1.187 & 0.427 & 3.301 \\
\hline \multicolumn{9}{|l|}{ Insurance } \\
\hline \multicolumn{9}{|l|}{ Medicare/ } \\
\hline \multicolumn{9}{|l|}{$\begin{array}{l}\text { Other } \\
\text { (reference) }\end{array}$} \\
\hline TennCare & 0.337 & 1.411 & 0.057 & 1 & 0.811 & 1.401 & 0.088 & 22.239 \\
\hline Medicare & 0.409 & 1.353 & 0.091 & 1 & 0.763 & 1.505 & 0.106 & 21.350 \\
\hline Private & 0.223 & 1.343 & 0.028 & 1 & 0.868 & 1.250 & 0.090 & 17.373 \\
\hline Self-pay & -0.654 & 1.755 & 0.139 & 1 & 0.709 & 0.520 & 0.017 & 16.216 \\
\hline $\begin{array}{l}\text { TennCare/ } \\
\text { Medicare }\end{array}$ & 0.395 & 1.439 & 0.075 & 1 & 0.784 & 1.484 & 0.088 & 24.903 \\
\hline
\end{tabular}

$\mathrm{n}=196$

Notes: B indicates logistic regression coefficient; S.E., standard error; Wald, Wald chisquare statistic; df, degrees of freedom; Sig., significance; HTN, hypertension; LOD, length of hypertensive disease; BP meds, blood pressure medications; HS, high school; GED, general education diploma. 
Table 4.17. Final regression model for serum creatinine within normal limits

\begin{tabular}{|c|c|c|c|c|c|c|c|c|}
\hline \multirow[t]{2}{*}{ Variable } & \multirow[t]{2}{*}{ B } & \multirow[t]{2}{*}{ S.E. } & \multirow[t]{2}{*}{ Wald } & \multirow[t]{2}{*}{ df } & \multirow[t]{2}{*}{ Sig. } & \multirow[t]{2}{*}{$\begin{array}{l}\text { Odds } \\
\text { Ratio }\end{array}$} & \multicolumn{2}{|c|}{$\begin{array}{l}95 \% \text { CI for } \\
\text { Odds Ratio }\end{array}$} \\
\hline & & & & & & & Lower & Upper \\
\hline Constant & 4.102 & 3.162 & 1.683 & 1 & 0.195 & 60.437 & & \\
\hline Adequate & 0.968 & 0.818 & 1.398 & 1 & 0.237 & 2.632 & 0.529 & 13.082 \\
\hline \multicolumn{9}{|l|}{ HTN } \\
\hline \multicolumn{9}{|l|}{ Knowledge } \\
\hline \multicolumn{9}{|l|}{$(\geq 70 \%$} \\
\hline & & & & & & & & \\
\hline \multicolumn{9}{|l|}{ LOD } \\
\hline \multirow{2}{*}{\multicolumn{9}{|c|}{$\begin{array}{l}\mathrm{LOD}<1 \\
\text { year } \\
\text { (reference) }\end{array}$}} \\
\hline & & & & & & & & \\
\hline $\begin{array}{l}\text { LOD 1-5 } \\
\text { years }\end{array}$ & 2.555 & 1.541 & 2.749 & 1 & 0.097 & 12.871 & 0.628 & 263.853 \\
\hline $\begin{array}{l}\text { LOD 6-10 } \\
\text { years }\end{array}$ & 1.815 & 1.455 & 1.558 & 1 & 0.212 & 6.144 & 0.355 & 106.320 \\
\hline $\begin{array}{l}\text { LOD 11-15 } \\
\text { years }\end{array}$ & 1.469 & 1.672 & 0.771 & 1 & 0.380 & 4.344 & 0.164 & 115.223 \\
\hline $\begin{array}{l}\text { LOD 16-20 } \\
\text { years }\end{array}$ & 2.064 & 1.735 & 1.415 & 1 & 0.234 & 7.877 & 0.263 & 236.026 \\
\hline $\begin{array}{l}\mathrm{LOD} \geq 20 \\
\text { years }\end{array}$ & 1.251 & 1.529 & 0.669 & 1 & 0.413 & 3.494 & 0.174 & 70.001 \\
\hline Married & 0.231 & 0.741 & 0.097 & 1 & 0.756 & 1.260 & 0.295 & 5.382 \\
\hline Monitors salt & -1.055 & 0.821 & 1.651 & 1 & 0.199 & 0.348 & 0.070 & 1.740 \\
\hline Exercises & 0.300 & 0.643 & 0.218 & 1 & 0.641 & 1.350 & 0.383 & 4.760 \\
\hline $\begin{array}{l}\text { Number of BP } \\
\text { meds }\end{array}$ & -0.789 & 0.285 & 7.646 & 1 & 0.006 & 0.454 & 0.260 & 0.795 \\
\hline $\begin{array}{l}\text { Number of } \\
\text { diseases }\end{array}$ & -0.942 & 0.367 & 6.584 & 1 & 0.010 & 0.390 & 0.190 & 0.800 \\
\hline Age & 0.007 & 0.035 & 0.041 & 1 & 0.840 & 1.007 & 0.940 & 1.079 \\
\hline \multicolumn{9}{|l|}{ Sex } \\
\hline \multicolumn{9}{|l|}{$\begin{array}{l}\text { Female } \\
\text { (reference) }\end{array}$} \\
\hline Male & 0.454 & 0.723 & 0.394 & 1 & 0.530 & 1.575 & 0.382 & 6.497 \\
\hline \multicolumn{9}{|l|}{ Race } \\
\hline \multicolumn{9}{|l|}{$\begin{array}{l}\text { Caucasian } \\
\text { (reference) }\end{array}$} \\
\hline $\begin{array}{l}\text { African } \\
\text { American }\end{array}$ & -2.494 & 1.022 & 5.960 & 1 & 0.015 & 0.083 & 0.011 & 0.612 \\
\hline
\end{tabular}


Table 4.17. (continued)

\begin{tabular}{|c|c|c|c|c|c|c|c|c|}
\hline \multirow[t]{2}{*}{ Variable } & \multirow[t]{2}{*}{ B } & \multirow[t]{2}{*}{ S.E. } & \multirow[t]{2}{*}{ Wald } & \multirow[t]{2}{*}{ df } & \multirow[t]{2}{*}{ Sig. } & \multirow[t]{2}{*}{$\begin{array}{l}\text { Odds } \\
\text { Ratio }\end{array}$} & \multicolumn{2}{|c|}{$\begin{array}{l}95 \% \text { CI for } \\
\text { Odds Ratio }\end{array}$} \\
\hline & & & & & & & Lower & Upper \\
\hline \multicolumn{9}{|l|}{ Education } \\
\hline \multirow{2}{*}{\multicolumn{9}{|c|}{$\begin{array}{l}\text { Less than } \\
\text { HS diploma } \\
\text { (reference) }\end{array}$}} \\
\hline & & & & & & & & \\
\hline $\begin{array}{l}\text { HS diploma } \\
\text { or GED }\end{array}$ & -1.607 & 0.840 & 3.658 & 1 & 0.056 & 0.200 & 0.039 & 1.041 \\
\hline $\begin{array}{l}\text { Greater than } \\
\text { HS diploma }\end{array}$ & 0.639 & 1.059 & 0.364 & 1 & 0.546 & 1.895 & 0.238 & 15.102 \\
\hline \multicolumn{9}{|l|}{ Insurance } \\
\hline \multicolumn{9}{|l|}{ Medicare/ } \\
\hline \multicolumn{9}{|l|}{$\begin{array}{l}\text { Other } \\
\text { (reference) }\end{array}$} \\
\hline TennCare & 1.981 & 2.107 & 0.884 & 1 & 0.347 & 7.247 & 0.117 & 450.564 \\
\hline Medicare & 1.603 & 1.760 & 0.829 & 1 & 0.362 & 4.968 & 0.158 & 156.468 \\
\hline Private & 1.881 & 1.898 & 0.982 & 1 & 0.322 & 6.562 & 0.159 & 270.924 \\
\hline Self-pay & 1.051 & 2.118 & 0.246 & 1 & 0.620 & 2.860 & 0.045 & 181.803 \\
\hline $\begin{array}{l}\text { TennCare/ } \\
\text { Medicare }\end{array}$ & 1.467 & 1.968 & 0.556 & 1 & 0.456 & 4.337 & 0.092 & 205.354 \\
\hline
\end{tabular}

$\mathrm{n}=175$

Notes: B indicates logistic regression coefficient; S.E., standard error; Wald, Wald chisquare statistic; df, degrees of freedom; Sig., significance; HTN, hypertension; LOD, length of hypertensive disease; BP meds, blood pressure medications; HS, high school; GED, general education diploma. 
Additionally, in this model African Americans were 92\% less likely to have a Scr within normal limits compared to their white counterparts, after controlling for all other variables in the model.

Because only 74 participants in the study had a diagnosis of diabetes, the logistic regression analysis for $\mathrm{HbAlc}$ at goal was conducted using all participants who had a HbAlc value available. Therefore, the analysis was run using 95 participants with the knowledge that there may be a lack of power to detect statistical significance. The results for this analysis are shown in Table 4.18. As with all of the other regression models, adequate hypertension knowledge was not significantly associated with having a HbAlc at goal. In this model, race was the only variable that achieved statistical significance. African Americans were $74 \%$ less likely to have a HbAlc at goal compared to their white counterparts.

Scores on the hypertension knowledge instrument were not a significant predictor of SBP control, DBP control, total blood pressure control, Scr within normal limits, or HbA1c at goal. Adequate blood pressure knowledge, defined as a score of $70 \%$ or higher on the knowledge instrument, was significantly correlated with education. Individuals with a high school diploma or a GED were 3.6 times more likely to have adequate hypertension knowledge compared to those with less than a high school diploma or GED. Also, individuals with more than a high school education were 7.6 times more likely to have adequate hypertension knowledge compared to those with less than a high school diploma or GED ( $p$-value $<0.001$ ). Additionally, those with private health insurance were 12.5 times more likely to have adequate hypertension knowledge compared to those with Medicare and a supplemental insurance $(\mathrm{p}$-value $=0.025)$. Finally, length of disease was significantly correlated with adequate hypertension knowledge. The odds of adequate hypertension knowledge peaked with those who had had a diagnosis of hypertension for 11 to 15 years compared to those who had a diagnosis for less than year. 
Table 4.18. Final regression model for $\mathrm{HbA1c}$ control

\begin{tabular}{|c|c|c|c|c|c|c|c|c|}
\hline \multirow[t]{2}{*}{ Variable } & \multirow[t]{2}{*}{ B } & \multirow[t]{2}{*}{ S.E. } & \multirow[t]{2}{*}{ Wald } & \multirow[t]{2}{*}{ df } & \multirow[t]{2}{*}{ Sig. } & \multirow[t]{2}{*}{$\begin{array}{l}\text { Odds } \\
\text { Ratio }\end{array}$} & \multicolumn{2}{|c|}{$\begin{array}{l}\text { 95\% CI for } \\
\text { Odds Ratio } \\
\end{array}$} \\
\hline & & & & & & & Lower & Upper \\
\hline Constant & 0.824 & 2.794 & 0.087 & 1 & 0.768 & 2.281 & & \\
\hline Adequate & -0.711 & 0.754 & 0.887 & 1 & 0.346 & 0.491 & 0.112 & 2.156 \\
\hline \multicolumn{9}{|l|}{ HTN } \\
\hline \multirow{2}{*}{\multicolumn{9}{|c|}{$\begin{array}{l}\text { knowledge }(\geq \\
70 \% \text { correct) }\end{array}$}} \\
\hline & & & & & & & & \\
\hline \multicolumn{9}{|l|}{ LOD } \\
\hline \multirow{2}{*}{\multicolumn{9}{|c|}{$\begin{array}{l}\text { LOD < } 1 \\
\text { year } \\
\text { (reference) }\end{array}$}} \\
\hline & & & & & & & & \\
\hline $\begin{array}{l}\text { LOD 1-5 } \\
\text { years }\end{array}$ & 1.395 & 1.435 & 0.944 & 1 & 0.331 & 4.033 & 0.242 & 67.211 \\
\hline $\begin{array}{l}\text { LOD 6-10 } \\
\text { years }\end{array}$ & 1.379 & 1.392 & 0.981 & 1 & 0.322 & 3.970 & 0.259 & 60.746 \\
\hline $\begin{array}{l}\text { LOD 11-15 } \\
\text { years }\end{array}$ & 0.767 & 1.500 & 0.262 & 1 & 0.609 & 2.154 & 0.114 & 40.710 \\
\hline $\begin{array}{l}\text { LOD 16-20 } \\
\text { years }\end{array}$ & -2.614 & 1.724 & 2.299 & 1 & 0.129 & 0.073 & 0.002 & 2.150 \\
\hline $\begin{array}{l}\mathrm{LOD} \geq 20 \\
\text { years }\end{array}$ & 0.547 & 1.474 & 0.138 & 1 & 0.710 & 1.728 & 0.096 & 31.051 \\
\hline Married & 0.267 & 0.623 & 0.183 & 1 & 0.668 & 1.306 & 0.385 & 4.424 \\
\hline Monitors salt & -0.429 & 0.667 & 0.414 & 1 & 0.520 & 0.651 & 0.176 & 2.404 \\
\hline Exercises & -0.066 & 0.541 & 0.015 & 1 & 0.904 & 0.937 & 0.325 & 2.703 \\
\hline $\begin{array}{l}\text { Number of BP } \\
\text { Meds }\end{array}$ & 0.244 & 0.258 & 0.891 & 1 & 0.345 & 1.276 & 0.769 & 2.117 \\
\hline $\begin{array}{l}\text { Number of } \\
\text { diseases }\end{array}$ & -0.398 & 0.304 & 1.712 & 1 & 0.191 & 0.671 & 0.370 & 1.219 \\
\hline Age & 0.009 & 0.030 & 0.097 & 1 & 0.756 & 1.009 & 0.952 & 1.069 \\
\hline \multicolumn{9}{|l|}{ Sex } \\
\hline \multicolumn{9}{|l|}{$\begin{array}{l}\text { Female } \\
\text { (reference) }\end{array}$} \\
\hline Male & 0.017 & 0.674 & 0.001 & 1 & 0.980 & 1.017 & 0.272 & 3.812 \\
\hline $\begin{array}{l}\text { Race } \\
\quad \text { Caucasian } \\
\text { (reference) }\end{array}$ & & & & & & & & \\
\hline $\begin{array}{l}\text { African } \\
\text { American }\end{array}$ & -1.351 & 0.631 & 4.593 & 1 & 0.032 & 0.259 & 0.075 & 0.891 \\
\hline
\end{tabular}


Table 4.18. (continued)

\begin{tabular}{|c|c|c|c|c|c|c|c|c|}
\hline \multirow[t]{2}{*}{ Variable } & \multirow[t]{2}{*}{ B } & \multirow[t]{2}{*}{ S.E. } & \multirow[t]{2}{*}{ Wald } & \multirow[t]{2}{*}{ df } & \multirow[t]{2}{*}{ Sig. } & \multirow[t]{2}{*}{$\begin{array}{l}\text { Odds } \\
\text { Ratio }\end{array}$} & \multicolumn{2}{|c|}{$\begin{array}{l}\text { 95\% CI for } \\
\text { Odds Ratio }\end{array}$} \\
\hline & & & & & & & Lower & Upper \\
\hline \multicolumn{9}{|l|}{ Education } \\
\hline \multicolumn{9}{|l|}{ Less than } \\
\hline \multicolumn{9}{|l|}{ HS diploma } \\
\hline $\begin{array}{l}\text { HS diploma } \\
\text { or GED }\end{array}$ & -0.943 & 0.728 & 1.675 & 1 & 0.196 & 0.390 & 0.093 & 1.624 \\
\hline $\begin{array}{l}\text { Greater } \\
\text { than HS } \\
\text { diploma }\end{array}$ & -0.465 & 0.846 & 0.302 & 1 & 0.583 & 0.628 & 0.120 & 3.297 \\
\hline \multicolumn{9}{|l|}{ Insurance } \\
\hline \multicolumn{9}{|l|}{ Medicare/ } \\
\hline \multicolumn{9}{|l|}{$\begin{array}{l}\text { Other } \\
\text { (reference) }\end{array}$} \\
\hline TennCare & -0.067 & 1.824 & 0.001 & 1 & 0.971 & 0.935 & 0.026 & 33.356 \\
\hline Medicare & 0.874 & 1.765 & 0.245 & 1 & 0.620 & 2.397 & 0.075 & 76.227 \\
\hline Private & 0.861 & 1.713 & 0.252 & 1 & 0.615 & 2.365 & 0.082 & 67.938 \\
\hline Self-pay & -0.792 & 2.115 & 0.140 & 1 & 0.708 & 0.453 & 0.007 & 28.568 \\
\hline $\begin{array}{l}\text { TennCare/ } \\
\text { Medicare }\end{array}$ & 0.572 & 1.868 & 0.094 & 1 & 0.759 & 1.772 & 0.046 & 69.007 \\
\hline
\end{tabular}

$\mathrm{n}=95$

Notes: B indicates logistic regression coefficient; S.E., standard error; Wald, Wald chisquare statistic; df, degrees of freedom; Sig., significance; HTN, hypertension; LOD, length of hypertensive disease; BP meds, blood pressure medications; HS, high school; GED, general education diploma. 


\section{Chapter 5. Discussion}

This chapter is composed of four sections. The first two sections discuss the results of the study and the limitations associated with the study design, respectively. The third section addresses the conclusions that were drawn from the study results. Finally, recommendations for future research are discussed in the fourth section of this chapter.

\section{Overview}

The primary purpose of the study was to describe the development and validation of an instrument that assesses the knowledge required of patients with hypertension to effectively manage their blood pressure. The secondary purpose of the study was to determine the association between hypertension knowledge and outcomes such as systolic and diastolic blood pressure and HbAlc. The Cronbach's alpha, a measure of internal consistency, for the original hypertension knowledge instrument was 0.597 (95\% CI: $0.505,0.672)$. The Cronbach's alpha for the refined hypertension knowledge instrument was 0.598 (95\% CI: 0.504, 0.674). Although the Cronbach's alpha did not reach the stated cut-off value of 0.70 , the achieved Cronbach's alpha was considered acceptable, especially for the first psychometric assessment. Additionally, the original instrument was comprised of only 14 questions and the refined instrument was comprised of 9 questions. Cronbach's alpha increases as the length of the instrument increases. The study started with a fairly short instrument that was further reduced. Therefore, the length of the instrument prevented the Cronbach's alpha from increasing much from the alpha of the original instrument. Exploratory factor analysis was used to identify the factor structure of the instrument and CFA was used to confirm the structure identified by the EFA. These analyses yielded a three-factor solution: diet, general hypertension knowledge, and risk factors and complications of hypertension.

There was no significant relationship between hypertension knowledge and any of the outcomes measured. Because no significant relationship between hypertension knowledge and outcomes was ascertained, the investigator sought to determine what was correlated with knowledge. The variables length of disease, education, and health insurance were all independently and significantly correlated with adequate hypertension knowledge.

\section{Limitations}

From the start of the study, the use of a convenience sample and recall bias with respect to past medical history were identified as limitations associated with conducting the study. These limitations were considered acceptable given the study resources. Past medical history was verified with the patient's medical chart. However, it is important to note that the results of this study can only be generalized to similar clinic settings, which 
are associated with a teaching medical center and treat mainly low-income minority patients.

One of the main limitations of the study was the sample size. The intended sample size of 200 was reduced to 196 due to incomplete data points. Even though the final sample size was not greatly different from 200 , this sample size may not have been sufficient to detect a relationship between hypertension knowledge and hypertension-related outcomes, especially the outcome variable HbA1c at goal for which there was a sample size of 95 in the final analysis. Because there was no effect size in the literature regarding the relationship between hypertension knowledge and hypertension-related outcomes, the investigator had to assume that the sample size rules for both confirmatory and exploratory factor analysis and logistic regression analysis were sufficient to conduct the study. Ideally, the investigator would have liked to collect more than the minimum sample size of 200. However, there were two reasons that prevented the investigator from recruiting more than 200 study subjects. First, as the sample size approached 200 subjects the investigator began having trouble encountering potential participants who had not already participated in the study or had not already declined to participate in the study. Secondly, the investigator was never allowed to conduct the study at the second clinic site for which the investigator had IRB approval.

Another limitation of the study was the inability to incorporate S-TOFHLA scores into the regression models. The investigator speculated that health literacy would mediate the relationship between knowledge and outcomes. However, this relationship could not be determined because only 74 out 200 respondents completed the S-TOFHLA. In order to further investigate this phenomenon, the investigator determined whether a relationship existed between completion of the S-TOFHLA and level of educational attainment. There was no significant relationship between level of educational attainment and completion of the S-TOFHLA. There was also significant response bias as evidenced by a mean S-TOFHLA score of approximately 25 , indicating adequate health literacy. Respondents were asked to complete the S-TOFHLA after answering the hypertension knowledge instrument questions. The majority of the respondents who declined to complete the S-TOFHLA simply responded that they did not want to do it. The STOFHLA measures functional health literacy using the Cloze procedure. The Cloze procedure involves the replacement of every fifth to seventh word in a passage with a blank and multiple choices for the correct word. ${ }^{55}$ Many of the respondents who did complete the S-TOFHLA had to read the passages out loud in order to choose an answer. Additionally, the way that the S-TOFHLA is printed for administration could have influenced whether or not the participant chose to complete the S-TOFHLA. As the respondent reaches the bottom of some of the pages of the S-TOFHLA, the sentences will start, but will end at the top of the next page. Therefore, respondents would have to look at the previous page in order to determine the correct answer for the blank on the next page. Based on these observations, the investigator got the impression that many of those that declined the S-TOFHLA were intimidated by it.

A fifth limitation of the study was that 4 of the 14 questions were questions that had "all of the above" as an answer option. The presence of this answer option perhaps decreased 
the discrimination ability of the instrument. It is possible that respondents defaulted to the "all of the above" answer choice even when they did not know the answer. It is important to note that respondents were instructed not to guess at the answer and if they did not know the answer to simply state that they did not know. These questions are ones that need to be re-written in future versions of the instrument to improve reliability.

Finally, the method of factor analysis has its own limitations. Currently there is no agreed upon sample size. However, based on the KMO statistic, there was sufficient sample size to conduct factor analysis. Additionally, conducting a factor analysis, especially an EFA, requires just as much subjective decision making as objective decision making. Therefore, someone else could potentially make different decisions about retaining items and defining factors and have results that are as valid as this study's results.

\section{Conclusions}

In summary, the hypertension knowledge instrument is an instrument with acceptable validity. However, as stated four of the instrument items need to be reworded in order to remove the "all of the above" answer option and to perhaps increase the discriminating power of the items within the instrument. Although the instrument did not reach the Cronbach's alpha cutoff of 0.70 , it is important to not place too much weight on this value. The final structure of the instrument was one that possessed acceptable internal consistency and a factor structure that made clinical and theoretical sense.

This study incorporated various variables of the ITHBC into the regression model in order to explain the relationship between hypertension knowledge and hypertension outcomes. However, no significant relationship between these two variables was identified. Demographic variables, race, age, sex and education, were included in the model as these are often reported in the literature to influence outcomes. Age and race continue to be important variables with respect to outcomes. In this study, race was found to have a significant relationship with having a Scr within normal limits and having a HbAlc at goal. In both models, African Americans were less likely to be within normal limits or at goal. Age was also found to have a significant relationship with diastolic blood pressure control. However, the demographic variables sex and education were not significantly associated with any of the outcome variables.

Although adherence to clinical guidelines and/or hypertensive medications were not measured in this study, perhaps more emphasis should be put on these variables and their relationship with hypertension outcomes and less emphasis on the demographic variables sex and education. The American Society of Hypertension states that the two gaps that must be closed in order to successfully manage hypertension are that of effective research and its clinical translation and prescriber recommendations and patient adherence and persistence to these recommendations. ${ }^{96}$ Currently, only $65 \%$ of patients with hypertension receive drug therapy treatment that is consistent with clinical guidelines. Additionally, only $50 \%$ of those who receive guideline-relevant treatment persist on their 
medication for a year. ${ }^{96}$ If the aforementioned statistics are applied to the current study, 130 out of 200 patients would have been prescribed medications according to the clinical guidelines. If we take $50 \%$ of this now smaller sample, only 65 out of the original 200 patients would still be taking their medications as indicated after a year of therapy. Research has shown that adherence to clinical guidelines by health care providers and patient adherence and persistence to medications to treat hypertension results in controlled blood pressure and a reduction in macrovascular and microvascular complications. Based on the patient population studied, patients appeared to know or at least had been told what they were supposed to do in order to successfully manage their high blood pressure. However, for this study knowledge was not significantly associated with blood pressure control. This finding lends itself to the idea that although $98.5 \%$ of the study population indicated that they were taking medication for their high blood pressure, they instead had been prescribed medications for their high blood pressure but was neither adherent nor persistent with their medication use. Therefore, future studies need to include a measure of adherence especially from the standpoint of the patient in order to get a clearer picture of the relationship between knowledge and outcomes. More research needs to be done in order to determine why knowledge does not translate into improved outcomes. Is it simply a matter of insufficient sample size or are there unmeasured factors that mediate this relationship? Perhaps these other unmeasured factors, such as adherence, are more important predictors of hypertension-related outcomes. The investigator feels that it is a combination of both factors, which can only be determined from additional research in the area.

\section{Recommendations for Future Research}

The following recommendations for future research stem from the results of this study:

1. Since this study represented the first time the psychometric properties of the hypertension knowledge instrument were tested, a follow-up study in a different population needs to be conducted in order to further verify the results of this study. Additionally, the four questions that had "all of the above" as an answer option should be rewritten so there is only one correct answer from which the respondent must choose.

2. No significant relationship existed between hypertension knowledge and health outcomes in this study. Additional research needs to be performed in order to further elucidate the mediating factors between knowledge and outcomes. The influence of variables, such as adherence to clinical treatment guidelines, adherence to medications, and self-efficacy with respect to treatment, on the relationship between hypertension knowledge and hypertension-related outcomes needs to be further investigated.

3. Additionally, because this study along with other studies cited insufficient sample size as a possible reason for not finding a relationship between hypertension 
knowledge and health outcomes, research needs to be done to determine the effect size and thus sample size necessary to detect a difference.

4. The relationship between current knowledge and the future development of complications associated with hypertension has not been established. Therefore, a longitudinal study in which respondent knowledge is assessed at the beginning of the study and respondents followed for the development of complications needs to be conducted.

5. The current study investigated adequate hypertension knowledge and hypertension-related outcomes with both variables as categorical variables and found no significant relationship between knowledge and outcomes. Future studies need to be conducted in order to determine whether a relationship between hypertension knowledge and outcomes exists if the variables are measured continuously. 


\section{List of References}

1 Ostchega Y, Yoon SS, Hughes J, Louis T. Hypertension awareness, treatment, and control - continued disparities in adults: United States, 2005-2006. 2008. Hyattsville, MD, National Center for Health Statistics.

2 Centers for Disease Control and Prevention. National diabetes fact sheet: General information and national estimates on diabetes in the United States, 2007. http://www.cdc.gov/diabetes/pubs/pdf/ndfs_2007.pdf. Accessed May 15, 2009.

3 Heron M, Hoyert DL, Murphy SL, Xu J, Kochanek KD, Tejada-Vera B. Deaths: Final data for 2006. http://www.cdc.gov/nchs/data/nvsr/nvsr57/nvsr57_14.pdf. Accessed May 15, 2009.

4 McInnes GT. How important is optimal blood pressure control? Clin Ther 2004;26 Suppl A:A3-A11.

5 Snow V, Weiss KB, Mottur-Pilson C. The evidence base for tight blood pressure control in the management of type 2 diabetes mellitus. Ann Intern Med 2003;138:587-592.

6 Chan JC, Ko GT, Leung DH et al. Long-term effects of angiotensin-converting enzyme inhibition and metabolic control in hypertensive type 2 diabetic patients. Kidney Int 2000;57:590-600.

7 Kohner EM. Microvascular disease: What does the UKPDS tell us about diabetic retinopathy? Diabet Med 2008;25 Suppl 2:20-24.

8 Patel A, Macmahon S, Chalmers J et al. Effects of a fixed combination of perindopril and indapamide on macrovascular and microvascular outcomes in patients with type 2 diabetes mellitus (the ADVANCE trial): A randomised controlled trial. Lancet 2007;370:829-840.

9 Rosen AB, Karter AJ, Liu JY, Selby JV, Schneider EC. Use of angiotensinconverting enzyme inhibitors and angiotensin receptor blockers in high-risk clinical and ethnic groups with diabetes. J Gen Intern Med 2004;19:669-675.

10 Scheen AJ. Prevention of type 2 diabetes mellitus through inhibition of the reninangiotensin system. Drugs 2004;64:2537-2565.

11 Bosworth HB, Powers B, Grubber JM et al. Racial differences in blood pressure control: Potential explanatory factors. J Gen Intern Med 2008;23:692-698.

12 National Center for Health Statistics. Health, United States, 2008 with chartbook on trends in the health of Americans. Hyattsville, MD: U.S. Department of Health and Human Services, 2008. 
13 Aubert L, Bovet P, Gervasoni JP, Rwebogora A, Waeber B, Paccaud F. Knowledge, attitudes, and practices on hypertension in a country in epidemiological transition. Hypertension 1998;31:1136-1145.

14 Ayotte BJ, Trivedi R, Bosworth HB. Racial differences in hypertension knowledge: effects of differential item functioning. Ethn Dis 2009;19:23-27.

15 Oliveria SA, Chen RS, McCarthy BD, Davis CC, Hill MN. Hypertension knowledge, awareness, and attitudes in a hypertensive population. J Gen Intern Med 2005;20:219-225.

16 Peters RM, Templin TN. Measuring blood pressure knowledge and self-care behaviors of African Americans. Res Nurs Health 2008;31:543-552.

17 Powers MJ, Wooldridge PJ. Factors influencing knowledge, attitudes, and compliance of hypertensive patients. Res Nurs Health 1982;5:171-182.

18 Sanne S, Muntner P, Kawasaki L, Hyre A, DeSalvo KB. Hypertension knowledge among patients from an urban clinic. Ethn Dis 2008;18:42-47.

19 Viera AJ, Cohen LW, Mitchell CM, Sloane PD. High blood pressure knowledge among primary care patients with known hypertension: A North Carolina Family Medicine Research Network (NC-FM-RN) study. J Am Board Fam Med 2008;21:300-308.

20 Ryan P. Integrated Theory of Health Behavior Change: Background and intervention development. Clin Nurse Spec 2009;23:161-170.

21 World Health Organization. Definition and diagnosis of diabetes mellitus and intermediate hyperglycaemia. http://www.idf.org/webdata/docs/ WHO_IDF_definition_diagnosis_of_diabetes.pdf. Accessed January 12, 2010.

22 Ad Hoc Committee on Health Literacy for the Council on Scientific Affairs AMA. Health literacy: A report of the Council on Scientific Affairs. JAMA 1999;281:522557.

23 Medline Plus: A Service of the U S National Library of Medicine and the National Institutes of Medicine. HbA1c. http://www.nlm.nih.gov/medlineplus/ency/article/ 003640.htm. Accessed April 12, 2010.

24 Chobanian AV, Bakris GL, Black HR et al. Seventh Report of the Joint National Committee on Prevention, Detection, Evaluation, and Treatment of High Blood Pressure. Hypertension 2003;42:1206-1252.

25 Fowler MJ. Microvascular and macrovascular complications of diabetes. Clinical Diabetes 2008;26:77-82. 
26 PASW ${ }^{\circledR}$ Statistics 18 for Window (Version 18.0.0) Somers, NY: IBM Corporation; 2009.

27 DeVellis RF. Scale development: Theory and application. 2nd ed. Thousand Oaks, CA: Sage Publications, 2003.

28 McDonald RP. Reliability theory for total test scores. Test theory: A unified treatment. Mahwah, NJ: Lawrence Erlbaum Associates, Inc., 1999;62-75.

29 SAS System for Windows XP (Version 9.1.3) Cary, NC: SAS Institute, Inc.; 2007.

30 Nurss JR, Parker RM, Williams MV, Baker DW. TOFHLA: Test of functional health literacy in adults. Hartford, MI: Peppercorn Books and Press, Inc., 1995.

31 Gazmararian JA, Williams MV, Peel J, Baker DW. Health literacy and knowledge of chronic disease. Patient Educ Couns 2003;51:267-275.

32 Williams MV, Baker DW, Parker RM, Nurss JR. Relationship of functional health literacy to patients' knowledge of their chronic disease: A study of patients with hypertension and diabetes. Arch Intern Med 1998;158:166-172.

33 Gaziano TA, Bitton A, Anand S, Weinstein MC. The global cost of nonoptimal blood pressure. J Hypertens 2009;27:1472-1477.

34 Alcocer L, Cueto L. Hypertension, a health economics perspective. Ther Adv Cardiovasc Dis 2008;2:147-155.

35 National Center for Health Statistics. Health, United States, 2009 with chartbook on trends in the health of Americans. Hyattsville, MD: U.S. Department of Health and Human Services, 2009.

36 Hertz RP, Unger AN, Cornell JA, Saunders E. Racial disparities in hypertension prevalence, awareness, and management. Arch Intern Med 2005;165:2098-2104.

37 Giles T, Aranda JM, Jr., Suh DC et al. Ethnic/racial variations in blood pressure awareness, treatment, and control. J Clin Hypertens (Greenwich) 2007;9:345-354.

38 Fiscella K, Holt K. Racial disparity in hypertension control: Tallying the death toll. Ann Fam Med 2008;6:497-502.

39 Bosworth HB, Dudley T, Olsen MK et al. Racial differences in blood pressure control: Potential explanatory factors. Am J Med 2006;119:70-15.

40 Kressin NR, Orner MB, Manze M, Glickman ME, Berlowitz D. Understanding contributors to racial disparities in blood pressure control. Circ Cardiovasc Qual Outcomes 2010;3:173-180. 
41 Curb JD, Pressel SL, Cutler JA et al. Effect of diuretic-based antihypertensive treatment on cardiovascular disease risk in older diabetic patients with isolated systolic hypertension. Systolic Hypertension in the Elderly Program Cooperative Research Group. JAMA 1996;276:1886-1892.

42 UK Prospective Diabetes Study Group. Tight blood pressure control and risk of macrovascular and microvascular complications in type 2 diabetes: UKPDS 38. BMJ 1998;317:703-713.

43 Hansson L, Zanchetti A, Carruthers SG et al. Effects of intensive blood-pressure lowering and low-dose aspirin in patients with hypertension: Principal results of the Hypertension Optimal Treatment (HOT) randomised trial. HOT Study Group. Lancet 1998;351:1755-1762.

44 Tuomilehto J, Rastenyte D, Birkenhager WH et al. Effects of calcium-channel blockade in older patients with diabetes and systolic hypertension. $N$ Engl J Med 1999;340:677-684.

45 Beulens JW, Patel A, Vingerling JR et al. Effects of blood pressure lowering and intensive glucose control on the incidence and progression of retinopathy in patients with type 2 diabetes mellitus: A randomised controlled trial. Diabetologia 2009;52:2027-2036.

46 Davis TC, Williams MV, Marin E, Parker RM, Glass J. Health literacy and cancer communication. CA Cancer J Clin 2002;52:134-149.

47 Andrus MR, Roth MT. Health literacy: A review. Pharmacotherapy 2002;22:282302.

48 Cutilli CC, Bennett IM. Understanding the health literacy of America: Results of the National Assessment of Adult Literacy. Orthop Nurs 2009;28:27-32.

49 Kutner M, Greenberg E, Jin Y, Paulsen C. The health literacy of America's adults: Results from the 2003 National Assessment of Adult Literacy. http://nces.ed.gov/pubs2006/2006483.pdf. Accessed July 15, 2009.

50 DeWalt DA, Berkman ND, Sheridan S, Lohr KN, Pignone MP. Literacy and health outcomes: A systematic review of the literature. J Gen Intern Med 2004;19:12281239.

51 Paasche-Orlow MK, Wolf MS. The causal pathways linking health literacy to health outcomes. Am J Health Behav 2007;31 Suppl 1:S19-S26.

52 Pandit AU, Tang JW, Bailey SC et al. Education, literacy, and health: Mediating effects on hypertension knowledge and control. Patient Educ Couns 2009;75:381385 . 
53 Davis TC, Michielutte R, Askov EN, Williams MV, Weiss BD. Practical assessment of adult literacy in health care. Health Educ Behav 1998;25:613-624.

54 Murphy PW, Davis TC, Long SW, Jackson RH, Decker BC. Rapid estimate of adult literacy in medicine (REALM): A quick reading test for patients. $J$ of Reading 1993;37:124-130.

55 Parker RM, Baker DW, Williams MV, Nurss JR. The test of functional health literacy in adults: A new instrument for measuring patients' literacy skills. J Gen Intern Med 1995; 10:537-541.

56 Baker DW, Williams MV, Parker RM, Gazmararian JA, Nurss J. Development of a brief test to measure functional health literacy. Patient Educ Couns 1999;38:33-42.

57 Baker DW, Parker RM, Williams MV, Clark WS, Nurss J. The relationship of patient reading ability to self-reported health and use of health services. Am J Public Health 1997;87:1027-1030.

58 Baker DW, Parker RM, Williams MV, Clark WS. Health literacy and the risk of hospital admission. J Gen Intern Med 1998;13:791-798.

59 Baker DW, Gazmararian JA, Williams MV et al. Functional health literacy and the risk of hospital admission among Medicare managed care enrollees. Am J Public Health 2002;92:1278-1283.

60 Baker DW, Gazmararian JA, Williams MV et al. Health literacy and use of outpatient physician services by Medicare managed care enrollees. $J$ Gen Intern Med 2004;19:215-220.

61 Scott TL, Gazmararian JA, Williams MV, Baker DW. Health literacy and preventive health care use among Medicare enrollees in a managed care organization. Med Care 2002;40:395-404.

62 Weiss BD, Palmer R. Relationship between health care costs and very low literacy skills in a medically needy and indigent Medicaid population. $J$ Am Board Fam Pract 2004; 17:44-47.

63 Endres LK, Sharp LK, Haney E, Dooley SL. Health literacy and pregnancy preparedness in pregestational diabetes. Diabetes Care 2004;27:331-334.

64 Grubbs V, Gregorich SE, Perez-Stable EJ, Hsu CY. Health literacy and access to kidney transplantation. Clin J Am Soc Nephrol 2009;4:195-200.

65 Morris NS, MacLean CD, Littenberg B. Literacy and health outcomes: A crosssectional study in 1002 adults with diabetes. BMC Fam Pract 2006;7:49. 
66 Rothman R, Malone R, Bryant B, Horlen C, DeWalt D, Pignone M. The relationship between literacy and glycemic control in a diabetes diseasemanagement program. Diabetes Educ 2004;30:263-273.

67 Schillinger D, Grumbach K, Piette J et al. Association of health literacy with diabetes outcomes. JAMA 2002;288:475-482.

68 Schillinger D, Barton LR, Karter AJ, Wang F, Adler N. Does literacy mediate the relationship between education and health outcomes? A study of a low-income population with diabetes. Public Health Rep 2006;121:245-254.

69 Tang YH, Pang SM, Chan MF, Yeung GS, Yeung VT. Health literacy, complication awareness, and diabetic control in patients with type 2 diabetes mellitus. $J$ Adv Nurs 2008;62:74-83.

70 Mancuso CA, Rincon M. Impact of health literacy on longitudinal asthma outcomes. J Gen Intern Med 2006;21:813-817.

71 Williams MV, Baker DW, Honig EG, Lee TM, Nowlan A. Inadequate literacy is a barrier to asthma knowledge and self-care. Chest 1998;114:1008-1015.

72 Gazmararian J, Baker D, Parker R, Blazer DG. A multivariate analysis of factors associated with depression: Evaluating the role of health literacy as a potential contributor. Arch Intern Med 2000;160:3307-3314.

73 Lincoln A, Paasche-Orlow MK, Cheng DM et al. Impact of health literacy on depressive symptoms and mental health-related: Quality of life among adults with addiction. J Gen Intern Med 2006;21:818-822.

74 Barragan M, Hicks G, Williams MV, Franco-Paredes C, Duffus W, del Rio, C. Low health literacy is associated with HIV test acceptance. J Gen Intern Med $2005 ; 20: 422-425$.

75 Fortenberry JD, McFarlane MM, Hennessy M et al. Relation of health literacy to gonorrhoea related care. Sex Transm Infect 2001;77:206-211.

76 Kalichman SC, Rompa D. Functional health literacy is associated with health status and health-related knowledge in people living with HIV-AIDS. J Acquir Immune Defic Syndr 2000;25:337-344.

77 Nokes KM, Coleman CL, Cashen M et al. Health literacy and health outcomes in HIV seropositive persons. Res Nurs Health 2007;30:620-627.

78 Paasche-Orlow MK, Cheng DM, Palepu A, Meli S, Faber V, Samet JH. Health literacy, antiretroviral adherence, and HIV-RNA suppression: A longitudinal perspective. J Gen Intern Med 2006;21:835-840. 
79 Wolf MS, Gazmararian JA, Baker DW. Health literacy and functional health status among older adults. Arch Intern Med 2005;165:1946-1952.

80 Sudore RL, Yaffe K, Satterfield S et al. Limited literacy and mortality in the elderly: The health, aging, and body composition study. J Gen Intern Med 2006;21:806-812.

81 Fang MC, Machtinger EL, Wang F, Schillinger D. Health literacy and anticoagulation-related outcomes among patients taking warfarin. J Gen Intern Med 2006;21:841-846.

82 Lindau ST, Basu A, Leitsch SA. Health literacy as a predictor of follow-up after an abnormal Pap smear: A prospective study. J Gen Intern Med 2006;21:829-834.

83 Miller DP, Jr., Brownlee CD, McCoy TP, Pignone MP. The effect of health literacy on knowledge and receipt of colorectal cancer screening: A survey study. $B M C$ Fam Pract 2007;8:16.

84 Peterson NB, Dwyer KA, Mulvaney SA, Dietrich MS, Rothman RL. The influence of health literacy on colorectal cancer screening knowledge, beliefs and behavior. $J$ Natl Med Assoc 2007;99:1105-1112.

85 Maddux JE. Self-efficacy and outcome expectancy: Their relationship and their effects on behavioral intentions. Cognit Ther Res 1982;6:207-211.

86 Schaffer SD, Yarandi HN. Measuring asthma self-management knowledge in adults. J Am Acad Nurse Pract 2007;19:530-535.

87 Gourley GK, Gourley DR, La Monica RE, Reed P, Solomon DK, Washington E. Development and validation of the pharmaceutical care satisfaction questionnaire. Am J Manag Care 2001;7:461-466.

88 Pett MA, Lackey NR, Sullivan JJ. Making sense of factor analysis: The use of factor analysis for instrument development in health care research. Thousand Oaks, CA: Sage Publications, 2003.

89 UT Medical Group. UT Medical Group Department of Family Medicine. http://www.utmedicalgroup.com/pages/depts/FamilyMedicine.html. Accessed April $13,2010$.

90 Tennessee Pharmacists Association. Effect of a community pharmacist in hypertensive patient management [not published]. 2009.

91 American Heart Association. American Heart Association High Blood Pressure Quiz. http://www.heart.org/HEARTORG/Conditions/HighBloodPressure/ AboutHighBloodPressure/

Test-Your-Blood-Pressure-IQ_UCM_303313_Article.jsp. Accessed January 10, 2010. 
92 Yang Y. African Americans' responses to direct-to-consumer advertising of prescription drugs [dissertation]. 2004. University of Tennessee Health Science Center.

93 Hosmer DW, Lemeshow S. Applied logistic regression. 2nd ed. New York: John Wiley \& Sons, Inc., 2000.

94 Landis RS. Measurement theory and psychometrics [class notes]. August 1, 2009.

95 Hatcher L. A step-by-step approach to using SAS for factor analysis and structural equation modeling. Cary, NC: SAS Institute, Inc., 1994.

96 Hill MN, Miller NH, DeGeest S. ASH position paper: Adherence and persistence with taking medication to control high blood pressure. J Clin Hypertens (Greenwich) 2010;12:757-764. 
Appendix A. Permissions 


\section{Appendix A.1. ITHBC}

$\begin{array}{ll}\text { Wolters KlUWer } & \begin{array}{l}\text { Lippincott Williams \& Wilkins } \\ 351 \text { W. Camden Street }\end{array} \\ \text { Bealth } & \begin{array}{l}4105284000 \text { tel } \\ \text { Baltimore, MD } 21201\end{array}\end{array}$

DATE: 9/23/09

Crescent Rowell

101 Sawyer Circle \#456

Memphis, TN 38103

Fee: $\$ 0.00$

Re: Clinical Nurse Specialist

Spec Mat: NUR, 2009; 23(3):164, Fig. 1

Dissertation / Non-commercial use

\section{CONDITIONS}

Permission is granted for your requested use. Retain this copy for your records. This permission is subject to the following conditions:

1) A credit line will be prominently placed and included: for books - the author(s), title of book, editor, copyright holder, year of publication; for journals - the author(s), title of article, title of journal, volume number, issue number and inclusive pages.

2) The requestor warrants that the material shall not be used in any manner which may be considered derogatory to the title, content, or author(s) of the material or to Wolters Kluwer Health.

3) Permission is granted for one time use only as specified in your correspondence. Rights herein do not apply to future reproductions, editions, revisions, or other derivative works.

4) Permission granted is non-exclusive, and is valid throughout the world in the English language only.

5) Wolters Kluwer Health cannot supply the requestor with the original artwork or a "clean copy."

6) The requestor agrees to secure written permission from the author (for book material only).

7) Permission is valid if the borrowed material is original to a Wolters Kluwer Health imprint (Lippincott, Williams \& Wilkins, Lippincott-Raven Publishers, Williams \& Wilkins, Lea \& Febiger, Harwal, Igaku-Shoin, Rapid Science, Little Brown and Company, Harper \& Row Medical American Journal of Nursing Co, and Urban \& Schwarzenberg - English Language). 


\title{
Appendix A.2. JNC-VII
}

\section{WOLTERS KLUWER HEALTH LICENSE TERMS AND CONDITIONS}

May 23, 2010

\author{
This is a License Agreement between Crescent Rowell ("You") and Wolters Kluwer Health ("Wolters Kluwer Health") \\ provided by Copyright Clearance Center ("CCC"). The license consists of your order details, the terms and conditions \\ provided by Wolters Kluwer Health, and the payment terms and conditions.

\begin{tabular}{|c|c|}
\hline License Number & 2425130211005 \\
\hline License date & May 09, 2010 \\
\hline Licensed content publisher & Wolters Kluwer Health \\
\hline Licensed content publication & Hypertension \\
\hline Licensed content title & $\begin{array}{l}\text { Seventh Report of the Joint National Committee on Prevention, } \\
\text { Detection, Evaluation, and Treatment of High Blood Pressure }\end{array}$ \\
\hline Licensed content author & Aram V. Chobanian \\
\hline Licensed content date & Dec 1, 2003 \\
\hline Volume Number & 42 \\
\hline Issue Number & 6 \\
\hline Type of Use & Dissertation/Thesis \\
\hline Requestor type & Individual \\
\hline $\begin{array}{l}\text { Title of your thesis / } \\
\text { dissertation }\end{array}$ & $\begin{array}{l}\text { The Development and Psychometric Testing of Hypertension } \\
\text { Knowledge Instrument in a Vulnerable Population }\end{array}$ \\
\hline Expected completion date & Dec 2010 \\
\hline Estimated size(pages) & 150 \\
\hline
\end{tabular}


$\begin{array}{ll}\text { Billing Type } & \text { Invoice } \\ \text { Billing Address } & 101 \text { Sawyer Circle \#456 }\end{array}$

Memphis, TN 38103

United States

Customer reference info

Total

0.00 USD

Terms and Conditions

Terms and Conditions

1. A credit line will be prominently placed and include: for books - the author(s), title of book, editor, copyright holder, year of publication; For journals - the author(s), title of article, title of journal, volume number, issue number and inclusive pages.

2. The requestor warrants that the material shall not be used in any manner which may be considered derogatory to the title, content, or authors of the material, or to Wolters Kluwer/Lippincott, Williams \& Wilkins.

3. Permission is granted for one time use only as specified in your correspondence. Rights herein do not apply to future reproductions, editions, revisions, or other derivative works. Once term has expired, permission to renew must be made in writing.

4. Permission granted is non-exclusive, and is valid throughout the world in the English language and the languages specified in your original request.

5. Wolters Kluwer Health/Lippincott, Williams \& Wilkins, cannot supply the requestor with the original artwork or a "clean copy."

6. The requestor agrees to secure written permission from the author (for book material only).

7. Permission is valid if the borrowed material is original to a LWW imprint (Lippincott-Raven Publishers, Williams \& Wilkins, Lea \& Febiger, Harwal, Igaku-Shoin, Rapid Science, Little Brown \& Company, Harper \& Row Medical, American Journal of Nursing Co, and Urban \& Schwarzenberg - English Language).

8. If you opt not to use the material requested above, please notify Rightslink within 90 days of the original invoice date.

9. Other Terms and Conditions:

$\mathrm{v} 1.0$

Gratis licenses (referencing $\$ 0$ in the Total field) are free. Please retain this printable license for your reference. No payment is required.

If you would like to pay for this license now, please remit this license along with your payment made payable to "COPYRIGHT CLEARANCE CENTER" otherwise you will be invoiced within $\mathbf{4 8}$ hours of the license date. Payment should be in the form of a check or money order referencing your account number and this invoice number RLNK10780915.

Once you receive your invoice for this order, you may pay your invoice by credit card. Please follow instructions provided at that time.

Make Payment To:

Copyright Clearance Center

Dept 001

P.O. Box 843006

Boston, MA 02284-3006

If you find copyrighted material related to this license will not be used and wish to cancel, please contact us referencing this license number 2425130211005 and noting the reason for cancellation.

Questions? customercare@copyright.com or +1-877-622-5543 (toll free in the US) or +1-978-646-2777. 


\section{Appendix A.3. TPA Hypertension Knowledge Questionnaire}

\section{Tennessee Pharmacists Association \\ 500 Church Street, Suite 650 - Nashville, Tennessee 37219 Phone: 615/256-3023 Fax: 615/255-3528

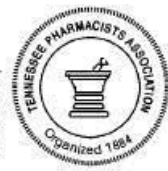

January 26,2010

Crescent E. Rowell, Pharm.D.

Ph.D. student

Health Outcomes and Policy Research Program

Department of Pharmaceutical Sciences

University of Tennessee College of Pharmacy

Re: Authorization to Use/Adapt Hypertension Knowledge Questionnaire

To Whom It May Concern:

As primary investigator for the research project entitled "Effect of Community Pharmacist Intervention in Hypertensive Patient Management," I authorize Crescent E. Rowell to utilize and/or adapt all documents and materials related to the above mentioned research project, including, but not limited to, the hypertension knowledge questionnaire.

Micah Cost

Director of Professional Affairs

Tennessee Pharmacists Association 


\section{Appendix A.4. AHA High Blood Pressure Quiz}

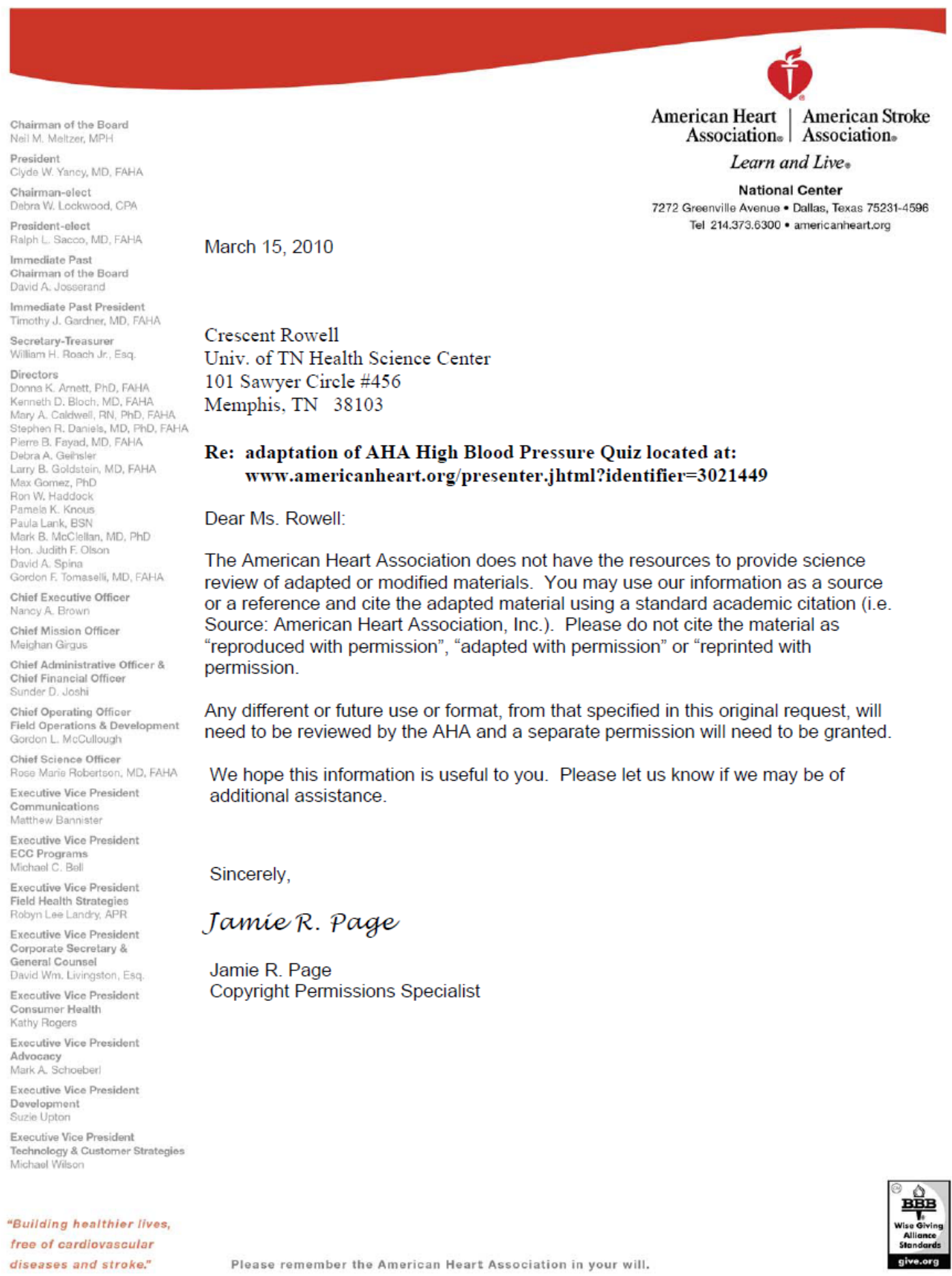


Appendix A.5. S-TOFHLA

\title{
PEPPERCORN BOOKS \& PRESS INC TOFHLA \\ TEST OF FUNCTIONAL HEALTH LITERACY IN ADULTS
}

\author{
LICENSE TO REPRODUCE THE TOFHLA \\ FOR USE IN TESTING OR RESEARCH
}

\begin{abstract}
Permission is granted to:
Crescent E. Rowell, University of Tennessee College of Pharmacy, Memphis, TN

to reproduce the TOFHLA for use in his/her own testing or research program, using the photocopy masters of the TOFHLA supplied with this order.
\end{abstract}

Reproduction for other purposes such as teaching, grant or funding applications, or general lending is not permitted and is covered by separate agreements. For information about these uses please contact the publisher.

License Number: 011/10

Issued: February 24, 2010

\author{
For further information, contact: \\ Peppercorn Books \& Press Inc \\ PO Box 693 \\ Snow Camp, NC 27349 \\ Phone: (336) 376-6935 \\ Fax: (336) 376-9099 \\ Email: post@peppercornbooks.com \\ Website: www.peppercornbooks.com
}




\section{Appendix A.6. Interview Flowchart}

\section{THEUNIVERSITYof \\ TENNESSEE \\ HEALTH SCIENCE CENTER}

\section{COLLEGE of PHARMACY}

Department of Pharmaceutical Sciences 847 Monroe Avenue, Room 227A Memphis, TN 38163 hone: (901) 448-6027 Fax: (901) 448-3446

Dr. Yi Yang

University of Mississippi College of Pharmacy

Department of Pharmacy Administration

234 Faser Hall

University, MS 38677

February 24, 2010

Dr. Yang,

I am a graduate student in the Health Outcomes and Policy Research program at the University of Tennessee Health Science Center, Memphis, TN. I am requesting permission to use and adapt the material cited below in my dissertation.

Request permission for:

Title of book: African Americans' Responses to Direct-to-Consumer Advertising of Prescription Drugs

Author: Yi Yang

Figure: Figure 3-1. Flowchart of interview procedures and informed consent dialog

This request shall encompass all future revisions and editions of the dissertation. You and your work will be duly and properly acknowledged.

If you have any questions about this request, please contact me at 901-487-5045 or crowell1@uthsc.edu. Please return a signed copy of this letter in the enclosed postage paid envelope. Please indicate your permission below.

Sincerely,

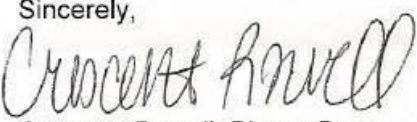

Crescent Rowell, Pharm.D

Graduate Student

Health Outcomes and Policy Research

The University of Tennessee Health Science Center

847 Monroe Avenue, Suite 205

Memphis, TN 38163
Permission granted:

$\frac{\text { Yer }}{\text { Signature }}$


Appendix B. Institutional Review Board Documents 


\section{Appendix B.1. UT IRB Approval 1}

\begin{tabular}{lr}
\hline THE UNIVERSITY OF TENNESSEE \\
Health Science Center \\
\hline \\
Institutional Review Board \\
Memphis, TN 38163 \\
Tel: (901) $448-4824$
\end{tabular}

March 18, 2010

Crescent Rowell, Pharm.D.

College of Pharmacy

Department of Pharmaceutical Sciences

$205 \mathrm{M}$ Johnson Building

Re: 10-00774-XP: The Development and Psychometric Testing of a Hypertension Knowledge Instrument in a Vulnerable Population

Dear Dr. Rowell,

The Administrative Section of the UTHSC Institutional Review Board (IRB) reviewed your application for the above referenced project.

The IRB determined your application to be consistent with the guidelines for expedited review under categories (5) and (7). Because of the inclusive dates of the records to be reviewed, this study status changed to expedited review. The study is approved for an alteration of consent under 45CFR46.116(d). The alteration consists in the substitution of a survey consent statement in lieu of informed consent interview and consent form. Written documentation of consist is waived under 45CFR46.117(c)(2). The IRB has reviewed these materials and determined that they do comply with proper consideration for the rights and welfare of human subjects and the regulatory requirements for the protection of human subjects. Therefore, this letter constitutes full approval by the IRB of your application as submitted including your survey and consent cover statement [stamped IRB approved on March 18, 2010]. This study was approved for 12 months with an expiration date of March 18, 2011.

This study may not be initiated until you receive approval from the institution(s) where the research is being conducted.

In the event that subjects are to be recruited using solicitation materials, such as brochures, posters, web based advertisements, etc., these materials must receive prior approval of the IRB. Any revisions in the approved application must also be submitted to and approved by the IRB prior to implementation. In addition, you are responsible for reporting any unanticipated serious adverse events or other problems involving risks to subjects or others in the manner required by the local IRB policy.

Finally, re-approval of your project is required by the IRB in accord with the conditions specified above. You may not continue the research study beyond the time or other limits specified unless you obtain prior written approval of the IRB.

Sincerely,

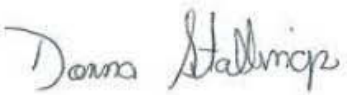

Signature applied by Donna L Stallings on 03/18/2010 10:49:10 AM CDT

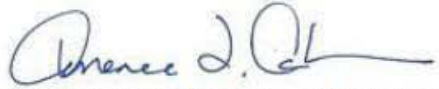

Signature applied by Terrence F Ackerman on 03/18/2010 10:50:00 AM CDT 


\section{Appendix B.2. UT IRB Approval 2}

\begin{tabular}{lr}
\hline THE UNIVERSITY OF TENNESSEE \\
Health Science Center \\
\hline Institutional Review Board \\
910 Madison Avenue, Suite 600 \\
Memphis, TN 38163 \\
Tel: (901) $448-4824$
\end{tabular}

April 8, 2010

Crescent Rowell, Pharm.D.

College of Pharmacy

Department of Pharmaceutical Sciences

205M Johnson Building

Re: 10-00774-XP: The Development and Psychometric Testing of a Hypertension Knowledge Instrument in a Vulnerable Population

Dear Dr. Rowell,

The Administrative Section of the UTHSC Institutional Review Board (IRB) reviewed your application for revision of your previously approved project, referenced above.

The Administrative section of the IRB determined your application to be consistent with the guidelines for expedited review as in 45 CFR 46.110 (b)(2).

The Board determined that approval of your revision application is dependent on a satisfactory response to the following administrative provisos.

You must respond to the following provisos using the PI Response to Review form found in your Incomplete Tasks and labeled as a Submission Correction located in the iMedRIS system online. NOTE: DO NOT complete a new Form 1, Form 2, Form 3, etc. to answer any provisos. Please use the PI Response to Review form to create any necessary revisions to study documents.

Submission provisos - Comments that must be met:

1. Associate Vice Chancellor Randall Nelson, Ph.D., Office of Research Compliance has informed us Dick Gourley has not completed the CITI training. Please direct him to www.citiprogram.org to complete the modules for Group 3. Revision request cannot be approved until he completes this online course.

Further review by the IRB is contingent upon submission of a satisfactory response. In the event the IRB does not receive a response to this letter within 60 days, this project will be considered inactive and reactivation may require resubmission of the original application for Board review.

Sincerely,

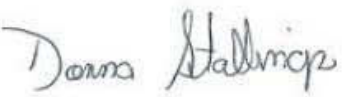

Signature applied by Donna L Stallings on 04/08/2010 10:10:29 AM CDT

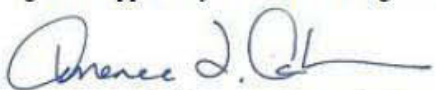

Signature applied by Terrence F Ackerman on 04/08/2010 10:11:13 AM CDT

Donna Stallings, CIM

Terrence F. Ackerman, Ph.D

IRB Analyst

Chairman 


\section{Appendix B.3. UT IRB Approval 3}

\begin{tabular}{lr}
\hline THE UNIVERSITY OF TENNESSEE \\
Health Science Center
\end{tabular}

April 13, 2010

Crescent Rowell, Pharm.D.

College of Pharmacy

Department of Pharmaceutical Sciences

205M Johnson Building

Re: 10-00774-XP: The Development and Psychometric Testing of a Hypertension Knowledge Instrument in a Vulnerable Population

Dear Dr. Rowell,

The IRB has received your written acceptance of and/or response dated April 12, 2010 to the provisos outlined in our correspondence of April 8, 2010 concerning revisions to your previously approved project, referenced above.

The Administrative Section of the IRB determined your application to fall under the guidelines of expedited review as in 45 CFR 46.110(b)(2). The IRB has reviewed these materials and determined that they do comply with proper consideration for the rights and welfare of human subjects and the regulatory requirements for the protection of human subjects. Therefore, this letter constitutes approval of the attached revisions. Approval does not alter the expiration date of this project, which is March 18, 2011.

The revisions to this study may not be instituted until you receive approval from the institution(s) where the research is being conducted.

In the event that subjects are to be recruited using solicitation materials, such as brochures, posters, webbased advertisements, etc., these materials must receive prior approval of the IRB. Any revisions in the approved application must also be submitted to and approved by the IRB prior to implementation. In addition, you are responsible for reporting any unanticipated serious adverse events or other problems involving risks to subject or others in the manner required by the local IRB policy.

Finally, re-approval of your project is required by the IRB in accord with the conditions specified above You may not continue the research study beyond the time or other limits specified unless you obtain prior written approval of the IRB.

Sincerely,

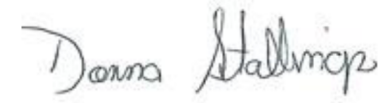

Signature applied by Donna L Stallings on 04/13/2010 06:23:21 AM CDT

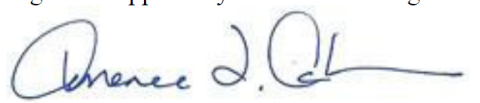

Signature applied by Terrence F Ackerman on 04/13/2010 06:24:28 AM CDT

Donna Stallings, CIM

IRB Analyst

UTHSC IRB
Terrence F. Ackerman, Ph.D.

Chairman

UTHSC IRB 
Attachment: Revisions

Crescent Rowell, Pharm.D.

Re: 10-00774-XP

April 13, 2010

Page -2-

1. The study application; version 1.1 is revised (a) under key study personnel to add Christa George and Amanda Howard-Thompson as co-investigators; (b) to add UT Medical Group, Inc., 1301 Primacy Parkway Family Medicine as a study site and (c) to remove the Med-Plex Endocrinology Clinic as a study site. No changes were made to the consent cover statement and/or the survey. 


\section{Appendix B.4. UT IRB Approval 4}

\begin{tabular}{lr}
\hline THE UNIVERSITY OF TENNESSEE \\
Health Science Center \\
\hline \\
Institutional Review Board \\
910 Madison Avenue, Suite 600 \\
Memphis, TN 38163 \\
Tel: (901) 448-4824
\end{tabular}

May 4, 2010

Crescent Rowell. Pharm.D.

College of Pharmacy

Department of Pharmaceutical Sciences

205M Johnson Building

Re: 10-00774-XP: The Development and Psychometric Testing of a Hypertension Knowledge Instrument in a Vulnerable Population

Dear Dr. Rowell,

The Administrative Section of the UTHSC Institutional Review Board (IRB) reviewed your application for revision of your previously approved project, referenced above.

The Administrative section of the IRB determined your application to be consistent with the guidelines for expedited review as in 45 CFR 46.110 (b) (2). Therefore, the attached revisions were approved in this regard and determined that they do comply with proper consideration of the rights and welfare of human subjects and the regulatory requirements for the protection of human subjects. Approval does not alter the expiration date of this project, which is March 18, 2011.

The revisions to this study may not be instituted until you receive approval from the institution(s) where the research is being conducted.

In the event that subjects are to be recruited using solicitation materials, such as brochures, posters, webbased advertisements, etc., these materials must receive prior approval of the IRB. Any revisions in the approved application must also be submitted to and approved by the IRB prior to implementation. In addition, you are responsible for reporting any unanticipated serious adverse events or other problems involving risks to subjects or others in the manner required by the local IRB policy.

Finally, re-approval of your project is required by the IRB in accord with the conditions specified above. You may not continue the research study beyond the time or other limits specified unless you obtain prior written approval of the IRB.

Sincerely,

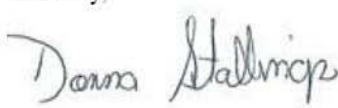

Signature applied by Donna L Stallings on 05/04/2010 11:44:25 AM CDT

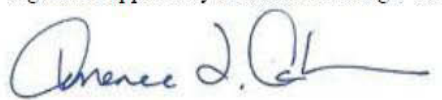

Signature applied by Terrence F Ackerman on 05/04/2010 11:45:24 AM CDT

Donna Stallings, CIM

IRB Analyst

Terrence F. Ackerman, Ph.D.

UTHSC IRB

Chairman

Attachment: Revisions 
Crescent Rowell, Pharm.D.

Re: 10-00774-XP

May 4, 2010

Page -2-

1. The study application; version 1.2 is revised to (a) add hemoglobin A1c as data will be obtained from the medical record; (b) clarified how participants will be recruited into the study. Stated that clinic personnel will identify for the investigator the patients with hypertension and then the investigator will ask the patient to participate in the study. Additionally, it was added that if participant recruitment does not go as planned, then charts will be reviewed for patients with hypertension. If this latter procedure is followed then the patient will sign the UTMG disclosure form upon presenting to the clinic and PHI will be extracted before the form is signed for participant identification and (c) an additional statement indicating study participants would also sign the UTMG PHI disclosure form. No changes were made to the consent cover statement.

2. The hypertension knowledge instrument is revised to (a) add Hemoglobin A1c and Serum creatinine (Scr) as these data points are being collected; (b) updated the race options; (c) add an ethnicity question; (d) education options updated; (e) add health insurance question; (f) added question regarding salt intake; (g) added question regarding physical activity; (h) hyperlipidemia added a response option to the question regarding past medical history and (i) minor editorial/verbiage changes. The revised hypertension instrument is dated April 28, 2010 [stamped IRB approved on May 4, 2010].

3. The inclusion of an additional form required by UTMG in order to obtain values such as the participant's blood pressure, hemoglobin A1c and other items that would be in the medical chart. 


\title{
Appendix B.5. Study Cover Letter
}

THEUNIVERSITYO

TENNESSEE

February 24, 2010

Dear Participant:

You have been invited to participate in a hypertension knowledge survey. This survey is part of a research study. If you choose to participate in this study, you will be asked a series of questions about your knowledge of hypertension. The survey will require 20 to 30 minutes of your time.

By completing the survey, you will be granting your permission to use your responses in this study. You will also be granting the investigator permission to access your medical records to obtain lab values necessary for the conduct of this study. All information about you and your survey responses will remain confidential.

You can stop answering the survey questions at any time. Additionally, you may refuse to answer one or all questions. You can ask me questions at any time. While there are no direct benefits to participating in this study, you may gain additional knowledge about managing your high blood pressure. There are no risks associated with this study. You will not be penalized for choosing not to participate in this study. Your participation in this study will not affect the care that you receive from your health care provider.

Thank you for your time and effort in participating in this study. Your response is valuable for the success of this study.

\author{
Sincerely, \\ Cressent Rowell \\ Crescent Rowell \\ Graduate Student \\ The University of Tennessee Health Science Center
}




\section{Appendix B.6. UTMG IRB Approval}

Dear Dr. Rowell:

This correspondence is being sent regarding UT Medical Group's (UTMG) review of the Study (Title: The Development and Psychometric Testing of a Hypertension Knowledge Instrument in a Vulnerable Population; PI: Crescent Rowell). You received IRB approval of the revision of the previously approved project on this date (May 4, 2010).

UTMG Action - Approved with the following stipulations and/or requirements:

-The appropriate UTMG Director of Operations and/or Clinic Manager is kept up-to-date on the Study's progress. The Director of Operations for the UTMG Department of Family Medicine is Robert Marriam. Mr. Marriam was copied on previous communications regarding the Study and has not submitted an objection.

-The UTMG Authorization for Use and/or Disclosure developed for the Study by Sherry Powell (UTMG's Director, Health Information Services) is used as previously discussed. Signed Authorizations should be forwarded to Ms. Powell, unless you are directed otherwise. Ms. Powell is copied

-You have completed UTMG's required Privacy Training and have signed UTMG's Confidentiality Agreement. UTMG Policies and Procedures concerning the HIPAA Privacy and Security Rules must be followed at all times. If you have any questions, please contact Carvin Vaughn (UTMG's Privacy Officer). Mr. Vaughn is copied.

-Additional information is provided upon request.

If you have any additional questions, please do not hesitate to call or email me. Thank you for your assistance.

Alisa

Alisa M. Firehock, MHA, FACHE

Director, Tennessee Clinical Trials Network

901-448-6977

alisa.firehock@tctn.org 


\section{Appendix B.7. Interview Flow Chart}

Hello. My name is Crescent Rowell. I am a graduate student at the University of Tennessee. I am interested in what you know about high blood pressure.

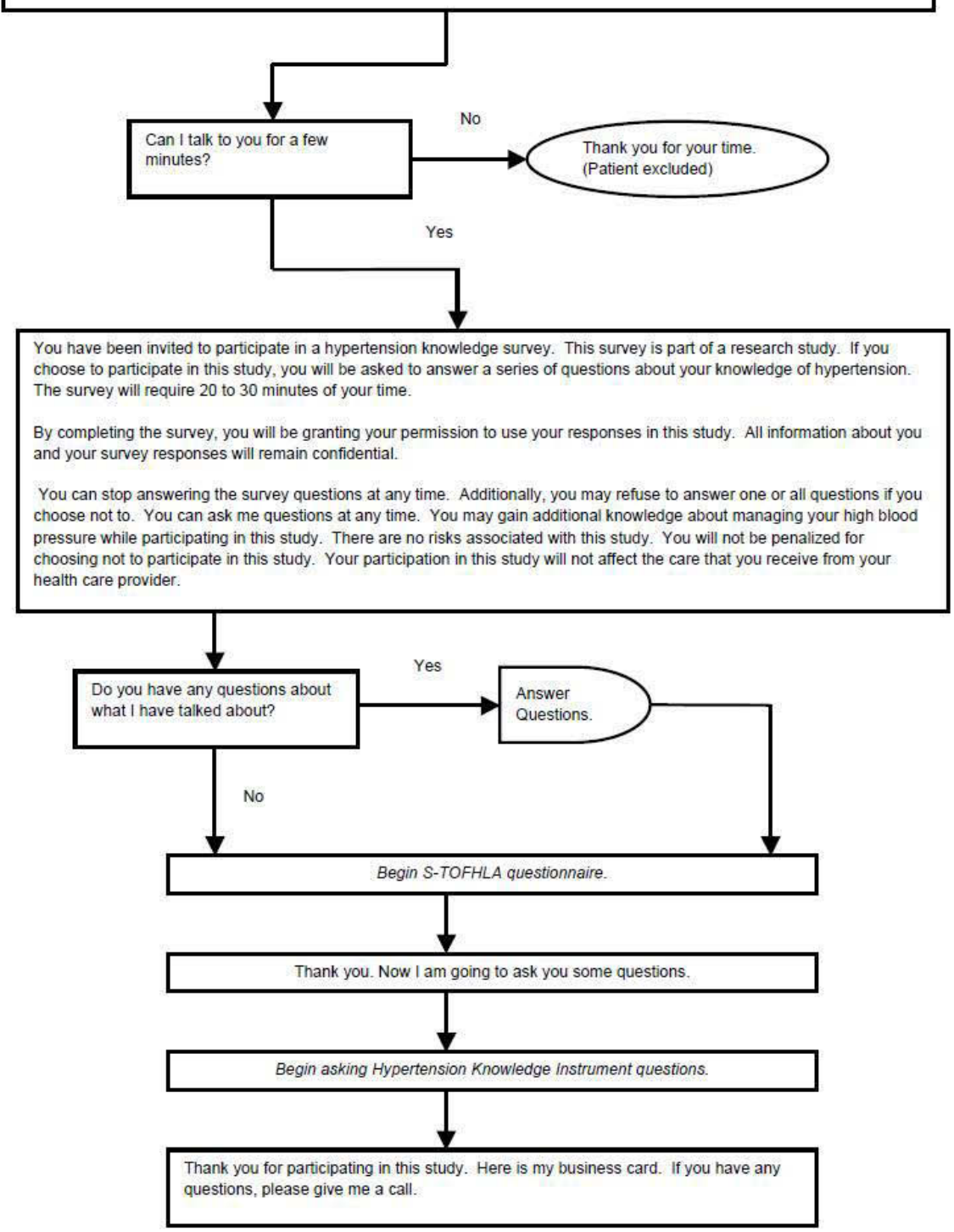


Appendix C. Study Instruments 


\section{Appendix C.1. Hypertension Knowledge Instrument}

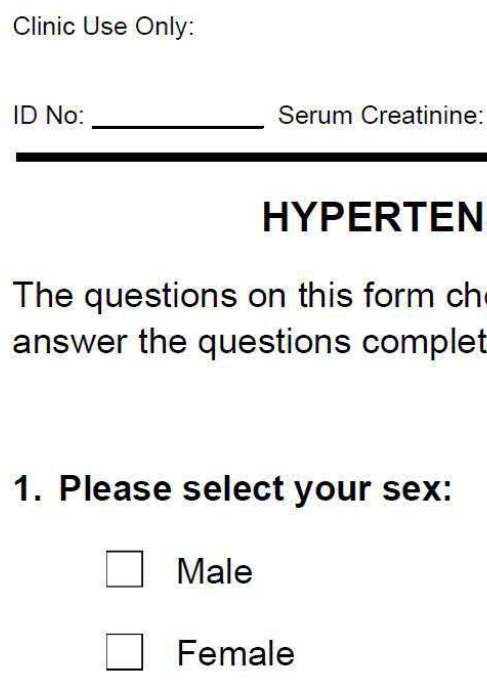

1. Please select your sex:

Male

$\square$ Female

\section{HYPERTENSION KNOWLEDGE INSTRUMENT}

The questions on this form check what you know about high blood pressure. Please answer the questions completely and the best that you can.

2. What is your date of birth?

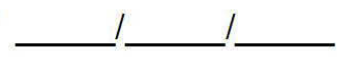

3. Please select the one that best describes you:

$\begin{array}{ll}\square \text { African American/Black } & \square \text { Caucasian/White } \\ \square \text { Asian or Pacific Islander } & \square \text { American Indian/Alaskan } \\ \text { Native }\end{array}$

\footnotetext{
4. Please select your ethnicity:

Hispanic

non-Hispanic

Adapted from the American Heart Association and Tennessee Pharmacists Association 
5. Please select the highest level of education that you have completed:

Some high school

High school diploma/GED

Some college

Associate's degree

\author{
Bachelor's degree \\ Master's degree \\ $\square$ Doctorate/Professional degree
}

6. Please select the category that best describes your health

insurance:

$\begin{array}{ll}\square \text { TennCare } & \square \begin{array}{l}\text { Other (Employer-sponsored, } \\ \text { government programs) }\end{array} \\ \text { Medicare } & \square \text { Self-pay (uninsured) }\end{array}$

Adapted from the American Heart Association and Tennessee Pharmacists Association Prepared 04/28/2010 
7. Do you have or have you been told by a health care provider that you have any of the following (check all that apply):

$\square$ Congestive heart failure $\quad \square$ Stroke
$\square \begin{aligned} & \text { Myocardial infarction } \\ & \text { (heart attack) }\end{aligned}$
$\square$ Peripheral vascular disease
$\begin{aligned} & \text { Increased serum } \\ & \text { creatinine }\end{aligned}$
$\square \begin{aligned} & \text { Type 1 diabetes } \\ & \text { (kidney disease) }\end{aligned}$
$\square \begin{aligned} & \text { Hyperlipidemia } \\ & \text { (high cholesterol) }\end{aligned}$

Adapted from the American Heart Association and Tennessee Pharmacists Association Prepared 04/28/2010 

Hgb A1c:

Blood Pressure:

8. How long have you had high blood pressure?

$\square$ less than 1 year
$\square 1$ to 5 years
$\square \quad 6$ to 10 years

9. Are you married?

$\square$ Yes $\quad \square$ No

10. Does your spouse have high blood pressure?
$\square$ Yes
$\square$ No

11. Does anyone else in your family have high blood pressure?
$\square$ Yes
$\square$ No

Adapted from the American Heart Association and Tennessee Pharmacists Association 
12. Has anyone provided you with information about your high

blood pressure?

$\square$ Yes

$\square$ No

13. Who provided you with information about your high blood pressure?

$\square$ Doctor

Pharmacist
Nurse

Other

14. Was the information you received about your high blood pressure helpful?
$\square$ Yes
$\square$ No

Adapted from the American Heart Association and Tennessee Pharmacists Association

Prepared 04/28/2010

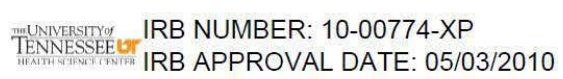


3. What are the symptoms of high blood pressure?
A. There are no symptoms of high blood pressure
B. Headache
C. Dizziness
D. Blurred vision

\section{Which of the following can make your blood pressure worse?}
A. Smoking cigarettes
B. Drinking large amounts of alcohol
C. Drinking large amounts of soft drinks
D. All of the above

Adapted from the American Heart Association and Tennessee Pharmacists Association 


\section{Uncontrolled high blood pressure can cause which of the}

\section{following?}
A. Stroke
B. Heart attack
C. Kidney disease
D. All of the above

6. How many days per week should you perform moderate intensity exercise for at least $\mathbf{3 0}$ minutes?
A. 5
B. 3
C. 4
D. 2

Adapted from the American Heart Association and Tennessee Pharmacists Association 
7. Which of the following groups has the highest risk for high blood pressure?
A. Caucasians
B. Hispanics
C. African Americans
D. Asians/Pacific Islanders

\section{How much sodium should a person with high blood pressure eat} each day?
A. 3,500 milligrams
B. 2,300 milligrams
C. 2,500 milligrams
D. 1,500 milligrams

Adapted from the American Heart Association and Tennessee Pharmacists Association 
Date:

ID No: Serum Creatinine:

$\mathrm{Hgb} \mathrm{A1c:}$

Blood Pressure:

\section{Which of the following are risk factors for high blood pressure?}
A. High alcohol consumption
B. Overweight
C. Family history of high blood pressure
D. All of the above

10. How can you improve your blood pressure?
A. Lose weight
B. Eat meals low in saturated fats, cholesterol, and salt
C. Take your blood pressure medications as directed by your health care provider
D. All of the above

Adapted from the American Heart Association and Tennessee Pharmacists Association 
11. How often should you take your blood pressure medication?
A. When you have a headache
B. When your stress levels are high
C. As directed by your health care provider
D. When you eat too much salt

12. Once you are diagnosed with high blood pressure, it usually lasts how long?
A. The rest of your life
B. Until the medications start working
C. A few years
D. 5 to 10 years

Adapted from the American Heart Association and Tennessee Pharmacists Association 
13. Which of the following will make your blood pressure worse?
A. High cholesterol
B. Salt/Sodium intake
C. Moderate physical activity
D. Fresh vegetables

14. How much sodium should a person with high blood pressure eat each day?
A. 1 teaspoon
B. Three-fourth teaspoon
C. One-fourth teaspoon
D. One-half teaspoon

Adapted from the American Heart Association and Tennessee Pharmacists Association 


\title{
Appendix C.2. S-TOFHLA
}

\author{
Short Test of Functional Literacy in Adults \\ STOFHLA \\ READING COMPREHENSION
}

HAND PATIENT THE READING COMPREHENSION PASSAGES TO BE

COMPLETED. FOLD BACK THE PAGE OPPOSITE THE TEXT SO THAT THE PATIENT SEES ONLY THE TEXT.

PREFACE THE READING COMPREHENSION EXERCISE WITH:

"Here are some other medical instructions that you or anybody might see around the hospital. These instructions are in sentences that have some of the words missing. Where a word is missing, a blank line is drawn, and 4 possible words that could go in the blank appear just below it. I want you to figure out which of those 4 words should go in the blank, which word makes the sentence make sense. When you think you know which one it is, circle the letter in front of that word, and go on to the next one. When you finish the page, turn the page and keep going until you finish all the pages."

STOP AT THE END OF 7 MINUTES

PASSAGE A: $\quad$ X-RAY PREPARATION

PASSAGE B: $\quad$ MEDICAID RIGHTS AND RESPONSIBILITIES 
PASSAGE A

Your doctor has sent you to have a ___ X-ray.
a. stomach
b. diabetes
c. stitches
d. germs

You must have an
a. asthma
b. empty
c. incest
d. anemia

stomach when you come for

a. is.

b. am.

c. if.

d. it.

The X-ray will from 1 to 3
a. take
a. beds
b. view
b. brains
c. talk
c. hours
d. look
d. diets

to do. 
THE DAY BEFORE THE X-RAY.

For supper have only a snack of fruit,
a. little
a. toes
b. broth
a. toes
c. attack
c. toast
d. nausea
d. thigh and jelly,

with coffee or tea.

After , you must not or drink
a. minute,
a. easy
b. midnight,
b. ate
c. during,
d. before,
c. drank
d. eat

anything at until after you have the X-ray.
a. ill
a. are
b. all
b. has
c. each
c. had
d. any
d. was

STOFHLA - Large Print Version, English 14 point font 
THE DAY OF THE X-RAY.

Do not eat
a. appointment.
b. walk-in.
c. breakfast.
d. clinic.

Do not
a. drive,
a. heart.
b. drink,
b. breath.
c. dress,
c. water.
d. dose,
d. cancer.

If you have any __ call the X-ray
a. answers,
a. Department
b. exercises,
b. Sprain
c. tracts,
c. Pharmacy
d. questions,
d. Toothache

at $616-4500$. 
PASSAGE B

I agree to give correct information to

if I can receive Medicaid.
a. hair
b. salt
c. see
d. ache

I ___ to provide the county information to
a. agree
a. hide
b. probe
b. risk
c. send
c. discharge
d. gain
d. prove

any

statements given in this
a. emphysema
b. application
c. gallbladder
d. relationship

the $\frac{\text { anflammation }}{\text { to get such proof. I }} \frac{\text { a. investigate }}{\text { that for }}$
$\begin{array}{ll}\text { b. religion } & \text { b. entertain } \\ \text { c. iron } & \text { c. understand } \\ \text { d. county } & \text { d. establish }\end{array}$

and hereby give permission to 
within
a. three
a. award
b. one
b. aware
c. five
c. away
d. ten
d. await

(10) days of becoming of the change.

I understand if I DO NOT like the
a. thus
b. this
c. that
d. than

a. marital

b. occupation

c. adult

d. decision

made on my

case, I have the to a fair hearing. I can
a. bright
b. left
c. wrong
d. right

a. request

b. refuse

c. fail

d. mend

hearing by writing or ___ the county where I applied.
a. counting
b. reading
c. calling
d. smelling

If you _ TANF for any family
a. wash
a. member,
b. want
b. history,
c. cover
c. weight,
d. tape
d. seatbelt, , you will have to 
a different application form.
a. relax
b. break
c. inhale
d. sign
a. Since,
b. Whether,
c. However,
d. Because,

, we will use

the $\frac{}{\text { a. lung }}$ on this form to determine your
$\begin{array}{ll}\text { b. date } & \text { a. hypoglycemia. } \\ \text { c. meal } & \text { c. eligibility. } \\ \text { d. pelvic } & \text { d. schizophrenia. }\end{array}$

STOFHLA - Large Print Version, English 14 point font

TENNESSEF IRB NUMBER: 10-00774-XP 


\section{Vita}

Crescent Elayne Rowell was born in Florence, AL in 1981. She completed her Bachelor of Science degree in chemistry from Rhodes College in Memphis, TN, in 2003. She then went on to complete a Doctor of Pharmacy degree in 2007 from the University of

Tennessee College of Pharmacy. Crescent served as the first Tennessee Pharmacists Association executive resident from 2007 until 2008. While completing her Doctor of Philosophy degree, Crescent worked part-time as a community pharmacist. Crescent will receive the Doctor of Philosophy degree from the University of Tennessee Health Science Center in December 2010. 